\title{
En fidelidad al evangelio \\ y al pueblo salvadoreño. \\ El diario pastoral \\ de Mons. Oscar A. Romero
}

\section{RODOLFO CARDENAL \\ Centro de Reflexión Teológica, San Salvador}

En estas páginas vuelvo sobre repetidos temas cuando se habla de la Iglesia salvadoreña y de Monseñor Romero en particular. Sin embargo, la perspectiva es novedosa porque la fuente que utilizo es el diario que Monseñor dejó grabado para la posteridad. En efecto, contamos con la existencia de una serie de grabaciones hechas por Monseñor que comienzan el 31 de marzo de 1978 y concluyen el 20 de marzo de 1980, cuatro dias antes del asesinato. No se han encontrado aún, si es que existen, las grabaciones de los 13 primeros meses de su arzobispado. En el diario no hay indicios de que hubiera esta primera parte que falta. Por otro lado, el diario tiene una laguna de tres meses ( 3 de julio a 1 de octubre de 1978) porque Monseñor no grabó. Así, pues, la novedad de estas páginas radica en esta fuente privilegiada, a la cual hasta ahora muy pocas personas han tenido acceso.

Contrariamente a lo que pudiera esperarse, este no es un diario ordinario en cuanto que no recoge en el los aspectos estrictamente personales de su autor, no hay intimidades, ni confesiones personales, ni sentimientos profundos, etc. Este diario es un diario pastoral, en el cual su autor fue registrando dia a dia su actividad como arzobispo de San Salvador, destacando aquellas actividades que más impacto le causaron y dando sobre ellas su juicio y sentir personal. En este sentido el diario es muy personal y revela una dimension de Monseñor hasta ahora desconocida. Al encontrarse en este texto biográfico la visión pastoral de Monseñor, el diario tiene también una dimensión personal, pero solamente de su labor como pastor en la arquidiócesis de San Salvador.

Más aún, Monseñor no debía estar muy satisfech $\rho$ con estas grabaciones porque en ellas se registraba "sólo la actividad y la actividad del propio obispo y yo quisiera que fuera llevándose un diario de toda la curia y de toda la vida de la arquidiocesis. Que esta es la hisloria que mucho interesará, sobre todo, en unos dias tan densos como nos toca vivir" (11 de diciembre de 1979). El mismo, pues, postergó su dimensión más personal e íntima, para dar paso a la arquidiócesis y a su tarea de pastor. Hay, claro, está, alusiones a visitas y 
entrevistas con su director espiritual y el psicólugo, pero sin dar ningún detalle sobre su contenido. En general, Monseñor fue muy delicado con las otras personas de quienes habla en el diario, con frecuencia las referencias personales son más bien vagas y sólo subraya los elementos públicos o importantes para la pastoral arquidiocesana. Solamente cuando es imprescindible identifica a las personas completamente. Tampoco se encuentran intimidades de otras personas.

Con toda su discreción, el diario permite, sin embargo, penetrar en una dimensión hasta ahora poco conocida de Monseñor Romero. En esta línea, el diario tiene una importancia singular porque ilumina algunas de sus actuaciones públicas, como su postura ante el golpe militar del 15 de octubre y las dos juntas de gobierno que se sucedieron y ante las organizaciones populares y su proyecto popular. Asimismo contiene material muy valioso para rechazar las acusaciones más comunes que sus enemigos y detractores han lanzado en su contra, tratando de desprestigiar su memoria. Monseñor Romero quiso ser el pastor de todos los salvadoreños, pero siempre siendo fiel al evangelio y al pueblo salvadoreño. Por eso luchó y por eso se entregó hasta las últimas consecuencias. En este sentido, el diario es una gran defensa de su actuación y lo presenta bajo una nueva luz, más claro y más grande.

Este trabajo se limita únicamente al diario y a lo que en el diario se encuentra. Responde a una simple pregunta, una vez conocida la existencia del texto y sabiendo que la mayor parte de la gente aún no tiene acceso directo a él, qué dice en el diario Monseñor Romero. Asumo que el lector conoce la historia de El Salvador en estos 3 ańos del arzobispado de Monseñor. Por eso, no abundo en datos históricos de esta clase. Sin embargo, conviene advertir brevemente que el diario tránscurre a lo largo de tres etapas politicas bien determinadas, antes del 15 de octubre de 1979, cuando se agotó e! modelo político represivo vigente desde hacía décadas. Una etapa de mucha represión y sin ninguna esperanza para mejorar la situación social de las mayorías de salvadoreños desposeídas de lo más elemental para vivir humanamente.

La segunda etapa se inicia con la ruptura de este modelo por medio del golpe militar del 15 de octubre de 1979. El golpe fue protagonizado por un grupo de militares jóvenes con intenciones reformistas y deseosos de implantar un régimen de derecho. Para la realización de este proyecto asociaron al poder a un destacado grupo de civiles. Pero la primera junta de gobierno muy pronto se encontró con graves dificultades. La izquierda desconoció sus intenciones $y$ sus escasas posibilidades reformistas, atacándola y, al mismo tiempo, justificando así la continuidad de la represión estatal. La derecha no la aceptó tampoco porque vio en grave peligro la continuidad de sus privilegios. Fueron breves meses de experimentación y de dolorosa esperanza hasta que triunfaron los sectores más derechistas de la Fuerza Armada. A comienzos de enero de 1980 el primer proyecto habia fracasado.

Los militares que sobrevivieron este fracaso buscaron la alianza con los demócrata cristianos, quienes habian quedado excluídos de la primera junta de gobierno, para integrar una segunda junta. El proyecto resultante combinó la represión con las reformas. Entonces se hizo evidente que no podía haber espe- 
ranza cristiana en este proyecto demócrata cristiano apoyado por Estados Unidos. El lector debe poner atención a estos tres períodos para comprender cabalmente algunas de las afirmaciones de Monseñor en el diario. Por eso, las citas respectivas aparecen claramente al lado de cada texto reproducido del diario.

El diario tiene su propio estilo, es un estilo oral poco cuidado. A veces el estilo es un tanto brusco, poco logrado, pero no por eso menos inteligible. He tratado de limar algunas de estas asperezas al citar el diario, pero respetando completamente el texio. Al leer estas citas el lector debe tener en mente que es Monseñor quien está hablando delante de una grabadora.

El material del diario de Monseñor Romero está estructurado en tres partes. En este número sólo publicamos las dos primeras partes, en las cuales se exponen su accesibilidad a todos los sectores y fuerzas sociales del país y su actividad pastoral en la arquidiócesis. La tercera parte contiene la visión personal de Monseñor Romero sobre la conflictividad eclesial que generó su ministerio arzobispal; algo que lo preocupó e hizo sufrir mucho. Esta última parte será publicada más tarde en esta misma revista.

Para terminar esta introducción quiero agradecer a Monseñor Rivera y a su Vicario General, Monseñor Ricardo Urioste, por haberme permitido utilizar este precioso material para profundizar en un gran cristiano salvadorefno y en un gran cristiano latinoamericano, Monseñor Oscar A. Romero.

\section{Un pastor abierto a todos}

Monseñor Romero fue un pastor cercano a todos los salvadoreños. El mismo se acercaba a su pueblo en las visitas a las comunidades, tal como lo detallaremos en el segundo capítulo y su pueblo se acercaba a él en la curia arzobispal y en el hospitalito. Se le acercaban los pobres y se le acercaban todas las fuerzas sociales del país. Es impresionante ver en su diario cómo van a visitarlo periodistas, diplomáticos, partidos políticos y funcionarios gubernamentales, militares, miembros de la oligarquía, organizaciones populares, obreros y campesinos, estudiantes y rectores de la universidad, víctimas de la represion, obispos, sacerdotes y agencias internacionaies, etc. Este hecho por sí mismo muestra que Monseñor Romero fue un pastor abierto a todos, bondadoso y comprensivo con todos, al mismo tiempo que firme y claro al decir a todos su palabra evangélica y eclesial.

Pero muestra también que Morseñor Romero se convirtio, sin él pretenderlo, en el centro de la vida del país. En los momentos sumamente conflictivos en que le tocó vivir, todos sintieron, incluso quienes más duramente lo atacaban, la necesidad de acudir a él. Monseñor Romero se hizo necesario para consolar e iluminar, para mediar o ayudar, para poner en contacto a las fuerzas sociales y politicas más antagónicas. 
En sus conversaciones era siempre claro y firme. Con las fuerzas de la derecha, a las que tan claramente denunciaba en sus homilias, fue respetuoso y ante ellas se mostró incluso esperanzado de poder cambiarlas, de poder convertirlas al evangelio. Con las fuerzas populares, a las cuales defendía públicamente en sus justas demandas, se mostró abierto y exigente en privado. Con todos los que sufrian se mostró sin excepción alguna como un pastor misericordioso.

\section{Los periodistas}

En el diario hay una masiva presencia de periodistas extranjeros, latinoamericanos, norteamericanos, canadienses, europeos e incluso algún japonés. Periodistas pertenecientes a toda clase de medios y de todas las tendencias ideológicas visitaron a Monseñor. En el diario se dice que todos fueron recibidos y atendidos, a veces a altas horas de la noche, después de un dia cargado de actividad. La televisión suiza, por ejemplo, lo acompañó una semana (5 de septiembre de 1979) en todas sus actividades para recoger su estilo de vida y de trabajo. La prensa menos presente en el diario fue la nacional, a la cual hay muy pocas alusiones y a la que Monseñor atacó por su falta de ética. En este sentido, se destaca la visita del director de La Crónica del Pueblo, un periódico de izquierda, de muy pequeño tiraje, el cual fue incendiado. Monseñor dio ánimos a su director, visitó el local quemado y promovió una colecta pública (18 de julio de 1979). Los otros dos medios nacionales destacados en el diario fueron las radios YSU que le preguntó sobre la posición de la Iglesia ante el conflicto social en septiembre de 1979 y Radio Cadena Central, la cual quería obligarlo a confrontar en público sus diferencias con Monseñor Aparicio, "pero le dije que no quería tocar temas polémicos y les reclamé porque varias veces insistió en el diálogo..." (21 de septiembre de 1979).

Los periodistas por lo general traían una sola pregunta, cómo miraba el arzobispo la crítica situación del país y cuál era el papel de la Iglesia. Otros tópicos relacionados con éste eran sus relaciones con el gobierno del general Romero y las dos juntas de gobierno posteriores, su visión de las organizaciones populares y si la pastoral de la arquidiócesis estaba inficionada de marxismo o comunismo como acusaban sus detractores.

Por su parte, Monseñor respondia a todas estas preguntas tratando de ser "sumamente claro y sincero, denunciando también los manejos que a veces se advierten en la publicidad de nuestro ambiente"' (29 de marzo de 1978). En otra ocasión comentó, después de una entrevista con la televisión alemana sobre la persecución, "creo haber expresado con toda franqueza y sinceridad mi pensamiento y haber defendido la posición de la lglesia" (17 de abril de 1978). Siempre su postura frente a la prensa fue "la reafirmación de la posición de la Iglesia frente a los malos entendidos y frente a las incomprensiones y persecuciones de que es objeto en este país" (21 de septiembre de 1979). Monseñor tenia clara conciencia de que estos encuentros con la prensa eran muy importantes para dar a conocer su posición en el pais y fuera de él. Tanto más que la prensa nacional le daba muy poca cobertura y cuando lo hacía era para 
atacarlo y tergiversar sus acciones y palabras. Por eso, aprovechaba siempre cualquiera de estos encuentros para decir lo que pensaba.

La tarea de atender a la prensa tenía sus dificultades. Con frecuencia ponian a prueba su paciencia, dos fotógrafos de revistas norteamericanas, por ejemplo, "me obligaban a tomar tantas poses como si fuera un artista" (19 de septiembre de 1979), y le consumian mucho tiempo, "sin embargo, creo que es una oportunidad maravillosa para extender la palabra y el pensamiento del pastor" (29 de agosto de 1979).

Otra dificultad era mantener siempre la perspectiva pastoral, aún cuando las preguntas fueran de carácter político. Asi, después del triunfo de la revolución sandinista, una radio de Costa Rica le preguntó su opinión al respecto, "siempre me coloqué en la perspectiva pastoral y evangélica, y evadí respuestas de carácter político" (31 de julio de 1979); sin embargo, meses más tarde hablando sobre el mismo tema defendió "los sentimientos cristianos en todo movimiento revolucionario para que sea verdaderamente servicio del pueblo, el cual es profundamente religioso" (10 de marzo de 1980). Es decir, que manteniéndose en la perspectiva pastoral no evadió los problemas concretos históricos. Por último, a pesar de las presiones, Monseñor nunca ventilo en la prensa los problemas intraeclesiales, a diferencia de algún otro obispo, quien sí lo atacó directamente en público.

El contacto personal de Monseñor causaba impacto en los periodistas. Muchos se despedían impresionados, haciendo grandes elogios de su personalidad y de su pastoral y cuestionados personalmente sobre su fe y el sentido de su vida. He aquí cómo Monseñor recogió una de estas confesiones en su diario, "yo agradezco al Señor que me dé este aire de personalidad que no quiero aprovechar para mi vanidad, sino para el mejor servicio de esta Iglesia" (4 de junio de 1979).

\section{Los diplomáticos}

Los embajadores y representantes de gobiernos extranjeros visitaban con frecuencia el arzobispado. Todos se presentaban para tomar contacto personal con Monseñor y para conocer su pensamiento sobre el país y la posicion de la Iglesia. No pocos se confesaban cristianos e incluso católicos y salian prometiendo ayudar al arzobispo, incluso económicamente, en su misión eclesial. Hasta el agregado cultural de la embajada norteamericana ofreció su colaboración para mejorar la grabación de las homilías en catedral, lo cual Monseñor aceptó y agradeció de inmediato (5 de marzo de 1979). El embajador de Nicaragua lo visitó para invitarlo oficialmente a visitar su país en febrero de 1980 . Ya en noviembre de 1980 había conversado sobre esta posibilidad con un dirigente del Movimiento Nacional Revolucionario (MNR), amigo personal suyo, y no quiso aceptar hasta que se aclararan las relaciones entre el gobierno sandinista y la jerarquia nicaragüense (22 de noviembre de 1979). Sin embargo, en la misa del domingo 22 de julio de 1979 empezó la homilia "con un saludo a Nicaragua ya que en esta semana realizo el principio de su liberación... Hemos orado por el pais... y hemos reflexionado, sacando consecuencias de este acon- 
tecimiento" (22 de julio de 1979). En distintas ocasiones, Monseffor distinguió entre el público de la misa dominical a algunos embajadores y varias veces reconoció a los funcionarios de la embajada norteamericana.

También eran frecuentes las visitas de los parlamentarios de los diversos paises quienes se presentaban acompañados de sus respectivos embajadores. El 3 de diciembre de 1978 lo visitaron los parlamentarios ingleses para comunicarle personalmente la postulación al premio Nóbel de la paz, lo cual, comento. "supone para mi un gran respaldo."

Las entrevistas con los embajadores tenian también objetivos más especificos. El diario recoge tres áreas de interes. La primera era pedir al arzobispo la mediación en las repetidas ocupaciones de las embajadas por las organizaciones populares y en algunos secuestros de personalidades extranjeras. Así, le pidieron mediar en la toma de las embajadas de Venezuela y Francia en mayo de 1979 y en la de España en febrero de 1980. Su actitud en estos casos era la de servicio, prometiendo hacer todo de su parte y poniendo a disposición el personal y la infraestructura del arzobispado, pero sabiendo siempre que el éxito de las mediaciones dependia de la buena voluntad de las partes en conflicto, las organizaciones y el gobierno. Su papel implicaba llevar y traer propuestas y contrapropuestas y tratar de ablandar las posturas tomadas por ambas partes. Una de sus preocupaciones principales era la situación personal de los rehenes o de los secuestrados. A los primeros los visitaba para darles ánimos e informarles de la marcha de las negociaciones. A veces, la mediación se volvía especialmente dificil, particularmente en el último caso, el de la embajada de España. Las Ligas Populares exigian conocer el paradero de algunos de sus militantes desaparecidos para salir de la sede diplomática, pero el gobierno no proporcionaba ninguna información. El 7 de febrero comentó en el diario,"... hay poca información de lo que hacen en sus operativos militares los guardias nacionales o porque el ministro de defensa no se presta a estas aclaraciones. Por su parte, les of reci interponer siempre mis oficios... aunque no está todo a mi disposición; sin embargo, noto un respaldo que puede ser atendido y usarse en bien de las vidas que están sufriendo en los rehenes..." En cambio, la postura del gobierno era mucho más intransigente. Los representantes diplomáticos de España e Italia comentó Monseñor, "están un poco abatidos" por la falta de información de parte del gobierno y de los cuerpos de seguridad. Finalmente, el 19 de febrero lo visitaron los embajadores liberados para agradecer sus intervenciones.

En la embajada de Nicaragua medió durante 6 largas horas, el 5 de noviembre de 1979, entre el gobierno y el Bloque Popular Revolucionario (BPR), el cual se había tomado dos ministerios, donde mantenian a muchos rehenes. Ahí se negoció la libertad de los rehenes y un pliego de peticiones que "el Bloque quiere obtener a toda costa." El 14 de diciembre de 1978 lo encontramos en la nunciatura formando parte de la comisión que intervino en la solución del secuestro de dos ingleses por las Fuerzas Armadas de la Resistencia Nacional (FARN), cuyas gestiones fracasaron ante la negativa del presidente Romero de reconocer la existencia de los presos politicos que le estaban pidiendo a cambio. 
Al caer la primera junta de gobierno, a principios de 1980 , Monseñor llamó al coronel Gutiérrez para mediar en la toma de la embajada de Panamá, donde estaba como rehén el embajador de Costa Rica, pero los ocupantes no aceptaron su mediación porque ya habian pedido la de los embajadores de México y Venezuela (13 de enero de 1980).

Monseñor participó asimismo muy activamente para tratar de salvar la vida del que fuera embajador de Sudáfrica en El Salvador. Antes de que se lo pidieran oficialmente hizo un llamado público en favor del embajador secuestrado y en contra de la ola de violencia que asolaba al país ("el señor nuncio me felicitó y dijo, "no podía estar mejor" ' comentó Monsen̂or el 2 de diciembre de 1979). En varias ocasiones estuvo con miembros de la familia del embajador secuestrado tratando de "darles consuelo y mucha confianza en Dios y de aceptar lo que él disponga y de mantener alto el espiritu para orar y para confiar" (19 de enero de 1980). Su interlocutor más frecuente por parte de la familia del embajador fue Ernesto Rivas Gallont, con quien se entrevistó en varias ocasiones para tratar asuntos relacionados con la liberación del embajador. En su último viaje a Roma se entrevistó con el embajador de Sudáfrica en aquella ciudad a quien puso al tanto de sus gestiones y de las dificultades para conseguir la liberación del embajador en EI Salvador por la falta de recursos para pagar el rescate exigido. Estas situaciones tan frecuentes durante su arzobispado le indicaban claramente "la necesidad de permanecer aqui, en su puesto, mientras no haya una verdadera necesidad de salir" (6 de febrero de 1980). Dijo esto a propósito de su último viaje a Roma y Lovaina, a donde precisamente por eso no queria ir.

La segunda área de interés específico con los embajadores y el cuerpo diplomático la constituyó la petición de apoyar el proyecto político demócrata cristiano. ese partido asumió el poder después de la primera junta, gracias a una alianza con los militares, en enero de 1980. Algunos embajadores relacionados con la democracia cristiana le pidieron más apoyo para ese partido en orden a que pudiera llevar a cabo el programa de reformas planteado. El embajador de Italia, ya el 13 de junio de 1978, le dijo que una democracia cristiana bien organizada seria muy útil para la doctrina social de la Iglesia. Sin embargo, el 14 de marzo de 1980, el embajador estaba desilusionado con el papel de los demócratas cristianos en el gobierno y prometió al arzobispo un encuentro con la alta dirigencia del partido para que, como pastor, les comunicara el pensamiento de la Iglesia y les recordara sus responsabilidades políticas.

Por último, y también relacionado con el aspecto anterior, la embajada de Estados Unidos siempre estuvo presente. Al llegar nuevos funcionarios de importancia a la embajada los llevaban a presentarse al arzobispado. Estos solían manifestarle mucho respeto y admiración por el trabajo pastoral de la arquidiócesis. El 11 de octubre de 1979 lo visitó el embajador con su asesor político para preguntarle oficialmente, en nombre del Departamento de Estado, sobre su juicio acerca de la crítica situación del pais en los últimos meses del gobierno del general Romero y cuál podía ser la solución. Monseñor respondió que teóricamente la respuesta era la apertura 
democrática, una alternativa que en la práctica era inviable por la poca credibilidad del gobierno y la represión. El ya sabia, desde mediados de septiembre, al menos, que se estaba planeando el golpe militar, por eso aprovechó la ocasión para pedir "al gobierno de Estados Unidos sus influencias para acelerar lo que teóricamente parece más útil, pero que, en la práctica se está destruyendo..." Días después del golpe, el embajador lo invitó a almorzar para sondear su opinión; Monseñor comentó en el diario, "una conversación muy interesante" y añadió, "tratamos de insinuar la ayuda que pudiera Estados Unidos prestar en este cambio para que fuera pacífico. Ofrecieron hacer todo lo que está a su alcance" (26 de octubre de 1979).

Más tarde, el 23 de enero de 1980, le informaron "muy confidencialmente" del plan de reformas de la democracia cristiana y los militares y de su buena voluntad para llevarlo a cabo, "...por nuestra parte," dijo Monsenor, "con mucha franqueza también expusimos nuestros crilerios". Estos reparos y reservas acerca del plan de reformas se los expresó a uno de los especialistas norteamericanos de la reforma agraria que le llegó a explicar el proyecto. Un proyecto "del gobierno que tiene poca popularidad," apuntó Monseñor. Agradeció la visita del técnico y se interesó por los detalles “...pero insinué estos reparos (su poca popularidad y el "querer condicionar a un proyecto impuesto, el deseo auténtico del pueblo") para que el proyecto con toda su ayuda económica fuera siempre contando con el sentimiento y el deseo del pueblo y no solamente apoyando un gobierno que por su aspecto represivo pierde cada dia más popularidad" (1 de marzo de 1980).

El 4 de marzo de 1980 volvieron los asesores norteamericanos del proyecto de reforma agraria. Monseñor dice en el diario que les hizo observaciones sobre el proyecto que le presentaron y que les expresó su dificultad principal, "si tendrá autoridad la junta de gobierno entre los dos extremos, de derecha y de izquierda, que la están combatiendo tan duramente" (14 de marzo de 1980).

Cuando Monseñor se distanció públicamente del proyecto demócrata cristiano y lo denunció en nombre de sus principios pastorales, sus intervenciones fueron criticadas por inclinarse más al proyecto popular que al demócrata cristiano. Monseñor respondió "que no se trataba de complacer a Estados Unidos o quedar bien con nadie, sino de buscar la solución que más conviene a nuestro país" (26 de enero de 1980). El Vaticano también le hizo saber suavemente que estaba al tanto de sus preferencias. En efecto, el cardenal Casaroli, en su última visita a Roma, le "revelo" que el embajador norteamericano lo había informado de su preocupación porque el arzobispo estuviera en "la línea revolucionaria" mientras que Estados Unidos apoyaba a los demócrata cristianos. "Yo le aclaré al señor Cardenal que no se trataba de una opción política, sino simplemente de buscar la justicia en la solución de los problemas del pueblo." La cosa no pasó a más, pues, el cardenal Casaroli le dijo a continuación que la visita del embajador no era oficial y que, además, la Iglesia "tenía que proceder no para complacer a las potencias de la tierra, sino de acuerdo con su fe y su conciencia en el evangelio" (31 de enero de 1980). 
También se opuso pública y tajantemente a la ayuda militar norteamericana. Después de haber leído y comentado en público su carta al presidente Carter, lo visitó un funcionario de la embajada de Estados Unidos para explicarle que la ayuda militar prometida a El Salvador no era para los cuerpos de seguridad ni tampoco se entregarian armas letales "...y asi otras explicaciones, que luego yo traté de contestar diciéndole que mi carta se basaba en una información y condicionadamente a esa información le hacía el comentario y que mantenía mis temores de que una ayuda militar, aunque fuera con las distinciones que él me explicaba, siempre redundaria en mayor represión del pueblo, ya que es el mismo ministro de defensa el que lleva ambos sectores..." (21 de febrero de 1980).

\section{Los partidos políticos}

Con bastante frecuencia, Monseñor desayunó, comió, cenó y conversó con los dirigentes de los partidos políticos más importantes, pero en especial con la democracia cristiana, a pesar de sus reservas sobre sus proyectos politicos. El objetivo de estas conversaciones era analizar la deteriorada situación nacional durante el régimen del general Romero, el golpe militar y la posibilidad de cooperar con los militares después del 15 de octubre de 1979, y finalmente, qué podian hacer los demócratas cristianos una vez ya en el poder. Por supuesto, además de estos temas, nunca faltaba cuál era la misión de la Iglesia en cada una de estas coyunturas. Monseñor calificó estos encuentros como diálogos muy interesantes y muy enriquecedores. Siempre dejó constancia en el diario de haberlos aprovechado para definir y reafirmar la misión de la Iglesia, "la cual no puede confundirse de ninguna manera con el partido politico, aunque busquen objetivos a veces parecidos" (11 de abril de 1978). A estas reuniones nunca asistió solo, siempre fue acompañado por sus asesores y en los casos más dificiles oía antes al senado presbiteral y a la comisión de pastoral.

Otra de sus preocupaciones muy suyas en estos encuentros frecuentes con los políticos era promover y animarlos a proponer proyectos políticos concretos para sacar al pueblo "de este remolino de violencia en que nos encontramos" (20 de abril de 1978) y para lograr implementar una auténtica democratización "en el sentido de dejar más participación de los salvadoreños en la gestión pública..." (20 de octubre de 1978) antes de la caída del general Romero. Después conversó con los dirigentes políticos, en especial con los demócratas cristianos, sobre la posibilidad de colaborar con la primera junta, en la cual puso muchas de sus esperanzas, en orden a afianzar el movimiento de los militares jovenes para lo'cual, les dijo, había que "tener valentía y franqueza... por el bien del país" (10 de noviembre de 1979). En concreto, Monseñor of reció patrocinar un encuentro entre el coronel Majano y los dirigentes de la democracia cristiana (16 de noviembre de 1979). Monseñor, como se irá viendo, creía firmemente que había que sumarse al movimiento iniciado por los militares jovenes para reforzarlo y orientarlo en beneficio de las mayorias pobres y desposeídas del país. Por eso su irrsistencia ante los demócratas cristianos, quienes habian quedado fuera de la primera junta. Monseñor tenía esperanzas 
en que los partidos políticos se convirtieran en instrumentos eficaces para implementar los proyectos políticos necesarios. A Duarte y Morales E., quienes llegaron a verlo al regreso de su exilio, les expresó su "sentido de servicio y de esperanza en los hombres políticos que tengan verdadero amor a la Iglesia. Y sobre todo si tienen inspiración cristiana" (19 de abril de 1979). En otra conversación con Morales E., fue más concreto "...le dije que la Iglesia tomaba muchas veces un papel de suplencia en defensa de los derechos humanos y del evangelio; muchas cosas que son, precisamente, los partidos políticos quienes deben hacerlo y que ojalá su retorno a El Salvador signilicara asumir esa responsabilidad..." (31 de julio de 1979). Asimismo recibió al coronel Claramount cuando regresó de su exilio y lo animó a continuar luchando. Comentando una entrevista con Calvani y otros dirigentes latinoamericanos de la democracia cristiana dijo "es interesante saber que hay tantas capacidades humanas y cristianas en el laicado para el desarrollo de nuestra América Latina" (3 de diciembre de 1979).

Cuando los demócrata cristianos llegaron por fin al poder, el coronel Majano y Morales Erlich le manifestaron sus esperanzas en las reformas y en concreto en la reforma agraria, la cual para ellos significaba un paso muy audaz. Monseñor los feliciló, pero también les señaló los riesgos, los peligros y las dudas. Los cuestionó, "por qué no se aseguraba más apoyo popular buscando un diálogo con las fuerzas populares y que no se consideraran todas como fuerzas de izquierda o de comunismo, sino con el afán de descubrir allí los verdaderos intereses del pueblo y las reivindicaciones por la justicia. Que no era lo mismo la extrema derecha que no trabajaba por estas reivindicaciones, sino por mantener sus privilegios. Y el tercer aspecto que criticaba era el aparecer muy sometidos a la voluntad de Estados Unidos, que recibieran la ayuda, pero que se procurara promover mucho la autonomía de nuestra patria..." Su resumen final del día fue el siguiente, "he dado gracias a Dios de haber vivido un día tan denso en relaciones que pueden beneficiar a nuestra Iglesia y a nuestro pueblo"' (14 de marzo de 1980).

Tres días más tarde lo visitó el ministro de agricultura y el de planificación, quienes además llegaron acompañados de otros funcionarios, para informarle de la marcha del proceso de la reforma agraria y para pedirle, como pastor, "que denuncie esta corrupción, estos egolsmos, y que pida también dentro de lo posible, una tregua para realizar en paz estas reformas... noté mucha franqueza y un deseo de tener éxito..." (17 de marzo de 1980).

Esto, sin embargo, nunca significó en Monseñor ingenuidad o confianza absoluta en la democracia cristiana. Al contrario, las diferencias fueron serias y sus reservas fueron aumentando a medida que veía cómo los demócratas cristianos en el poder, en la segunda junta de gobierno, eran incapaces de detener la represión. Ya desde el $\mathbf{1 2}$ de febrero, cuando el subsecretario de agricultura lo visitó para entregarle el proyecto de reforma agraria, Monseñor reaccionó diciendo que primero estudiaría el proyecto con sus asesores, pero le advirtió sin más "lo decisivo que será que la democracia cristana constate si las fuerzas armadas quieren o no quieren la transformación necesaria..." (12 de febrero de 1980). 
A un antiguo politico venezolano, quien llegó a solicitarle más apoyo para la democracia cristiana en orden a salvar el pais, Monseñor le dijo "que estaba de acuerdo (en lo de salvar el país), pero ante todo quiero ser fiel a mi pueblo y reclamar a la democracia lo que el pueblo le reclama y para lo cual tiene hoy una posibilidad, sobre todo para hacer que el ejército cese de su represión que está tan violenta contra nuestro pueblo" (11 de febrero de 1980).

El diario también recoge otras entrevistas con dirigentes de otros partidos políticos como el MNR, con cuyo dirigente, Guillermo Ungo, analizó las posibilidades de presentarse unidos al foro convocado para dialogar por el general Romero, quedando claro que "no podíamos presentar como una acción conjunta, como si la Iglesia se asociara a un partido político" (23 de mayo de 1979); hasta los dirigentes del Partido Unionista Centroamericano (PUCA) llegaron a pedirle su ayuda para unir Centroamerica y para que les otorgaran la personería jurídica y les entregaran las funciones y los edificios de la Organización de Estados Centroamericanos (25 de enero de 1980). Los partidos políticos de la oposición y las organizaciones populares que participaban en el foro popular le presentaron una plataforma común sobre la cual comentó "me pareció buena y creo que es un camino más que se ofrece a la racionalidad... les felicité y les prometí prestar todo mi apoyo de parte de la Iglesia (21 de septiembre de 1979).

El 29 de noviembre de 1979 se entrevistó con el secretario general de la Unión Democrática Nacionalista (UDN), "un marxista y tuvo palabras muy elogiosas para el trabajo de la Iglesia. Dijo que era muy distinto de otros tiempos, cuando su marxismo llamaba a la Iglesia 'opio del pueblo' que ahora, al contrario, la Iglesia era su mejor despertador... El queria ofrecerme un diálogo para buscar caminos..."

En el diario se registran, además, muchas visitas no especificadas de ministros, altos funcionarios públicos y personalidades políticas nacionales. Casi todos llegaban presentándose como católicos que estaban de acuerdo con sus planteamientos pastorales y luego le ofrecian sus servicios y colaboración para continuar. Con todos conversó y a todos les expuso con sencillez y franqueza, al menos esas eran sus intenciones, la posición de la Iglesia, "los deseos y temores ante el gobierno...," en particular antes del golpe del 15 de octubre de 1979.

A quienes desempeñaron cargos en las dos juntas de gobierno posteriores los animo y les dio consuelo en las dificultades, en concreto cuando se vieron en medio de las fuerzas de la izquierda y de la derecha. Trató de decirles que como hombre de fe y de esperanza tenian que servir con generosidad al país y tenian que aceptar los riesgos con rectitud de intención. "Creo," dijo Monseflor, "que debo animar la esperanza de todos los que sienten la preocupación por el pais" (11 de enero de 1980). Como se verá con más detalle en la siguiente parte, esto tenia un límite, detener la represión. Y cuando ello no fue posible y las renuncias se produjeron una a una, Monseñor los animó igualmente diciéndoles que, en conciencia, habian hecho lo correcto. 


\section{Los militares}

Los militares salvadoreños, de diferente graduación y tendencia política, se acercaron a Monseñor, por lo general en la noche y con carácter privado. Estas visitas las recibia en su residencia, en el hospitalito. El 28 de marzo de 1979 conversó con militares que calificó como "progresistas" sobre las posibles soluciones para salir de la crisis. "Por parte de la Iglesia, nosotros admiramos su buena voluntad. Agradecimos el enriquecimiento que nos habían dado con sus informes y nos ofrecimos a colaborar. La Iglesia siempre está dispuesta a colaborar cuando se ve de parte del gobierno sincero deseo de servir al pueblo, al que la Iglesia también sirve. El diálogo se tornó muy interesante y creo que todos salimos con un poco de esperanza más en el corazón." Según le explicaron los militares, ellos conversaban con frecuencia con el general Romero a quien Monseñor esperaba le hicieran llegar su mensaje sobre cómo y cuándo podria reanudarse el diálogo interrumpido desde marzo de 1977.

A mediados de 1979, en julio, recibió una visita confidencial de un mayor del ejército quien le confesó la corrupción existente entre los altos jefes y lo informó de la existencia de un grupo de militares sanos, quienes querían su vocación castrense con honradez. Monseñor lo animó a continuar dentro de este espiritu en lugar de retirarse como él quería (27 de julio de 1979). Más tarde, el 25 de septiembre de 1979, otro militar llegó a conversar sobre la situación y de los propósitos de un golpe contra el general Romero. El 17 de septiembre de 1979, según el diario, uno de sus vicarios generales le entregó tres comunicados de los militares progresistas que estaban planeando el golpe, "esto nos llena de esperanza y ojalá que pronto El Salvador respire aires mejores que el actual ambiente de violencia que vivimos," comentó Monseñor (17 de septiembre de 1979). El 7 de octubre, otros dos militares lo informaron de un golpe contra el general Romero que ya estaba en proceso. Monseñor comentó lo siguiente, "estaremos a la expectativa durante esta semana, mientras tanto, les prometí mis oraciones y toda la colaboración moral que la Iglesia puede ofrecer en tan delicadas circunstancias." Después del golpe siempre mantuvo contacto con los militares jóvenes, quienes por su parte lo visitaron con frecuencia para informarle de la marcha del proceso y de sus dificultades. Monseñor no identificó en el diario por su nombre a ninguno de estos militares. Después de una de estas conversaciones dejó constancia de lo que más le llamaba la atención de este grupo, "vi la buena voluntad de esta juventud militar, el deseo sincero de ofrecer a la patria un contributio (sic) de verdadera liberación y una búsqueda en el pensamiento de la Iglesia para ser mejor este momento de un proceso de democratización. Tuvimos franca libertad para exponer los puntos de la lglesia..." (12 de noviembre de 1979).

Los militares de alta graduación y de generaciones anteriores también sintieron la necesidad de acercarse a Monseñor, haciéndole "revelaciones sensacionales" sobre los desórdenes internos del ejército y del buen espíritu que existia en la juventud militar para purificar a los elementos corrompidos (13 de noviembre de 1979).

Asimismo se acercaron otros militares, como el general Medrano con 
quien tuvo un diálogo "muy interesante". El general llegó a comentar con Monseñor "las muchas imprudencias, desórdenes y errores" que estaba cometiendo el régimen del general Romero y la Fuerza Armada y el gran capital. Monseñor comentó en su diario que el general Medrano tenia muy buena información puesto que conocía desde dentro al gobierno y al ejército por la posición tan destacada que había ocupado en él a finales de los años 60, "estuvimos muy de acuerdo en muchas cosas y me prometió su ayuda, así como yo también le ofreci una colaboración siempre en bien del país" (14 de junio de 1979).

El ministro de defensa del general Romero, el coronel Iraheta, se presentó para comunicarle que habian estado conversando con el presidente Romero y con otros altos funcionarios, en la vela del hermano del presidente, asesinado en Apopa, sobre el peligro que corría su vida y le venia a of recer oficialmente protección, incluso un auto blindado. Monseñor agradeció al ministro el orrecimiento, le pidió saludar y dar su pésame al general Romero, añadiendo "respetuosamente que no aceptaba esa protección ya que yo querria correr los mismos riesgos que está corriendo el pueblo, que sería un anti-testimonio pastoral andar yo muy seguro, mientras el pueblo está tan inseguro." Además, Monsenor aprovechó la oportunidad para pedir protección para el pueblo en ciertas zonas, como en el departamento de Chalatenango, donde el ejército y los cuerpos de seguridad estaban sembrando el terror, para informar que él mismo habia sido víctima de abusos de autoridad militar en sus salidas apostólicas por los pueblos de la arquidócesis y para observar la situación de tolerancia ante los crímenes como el de los sacerdotes, "a veces parece voluntaria la suspensión de estas investigaciones." Su juicio global de la conversación fue el siguiente, "me parecio provechosa en el sentido de denuncia respetuosa ante quien puede poner remedio"' (17 de septiembre de 1979).

Después del golpe del 15 de octubre lo visitó el nuevo director de la Guardia Nacional, actual ministro de defensa, Eugenio Vides Casanova, quien empezó felicitándolo por sus homilias, las cuales habia oído desde hacía mucho tiempo, sin perderse ninguna, pues cuando salía de la capital dejaba a su hijo encargado que se las grabara. El director de este cuerpo de seguridad lo felicitó, además, por su "ideología que él ha tratado de captar y que cree que es la que urge en el país. Me alegré de esta coincidencia..." y entonces Monseñor pasó a aprovechar la ocasión, como era tan característico de él en estas situaciones, para comentar "los diversos abusos y anomalias que a lo largo del gobierno pasado se notaba en la guardia...," se quejó también de "la incomprension para nuestro trabajo pastoral y ofrecimos todo lo que esiuvo a nuestro alcance como colaboración en el noble esfuerzo de tener un dia unos cuerpos de seguridad que de veras sean respetados y no temidos..." (8 de noviembre de 1979).

El ministro de defensa de la primera junta de gobierno, el general Guillermo Garcia, y su subsecretario se sintieron obligados a visitar al arzobispo para explicarle que ellos también tenian deseos sinceros de transformar y cambiar el pais $y$, por lo tanto, era una injusticia acusarlos de la derechización del proceso, tal como lo habia hecho él en la homilía del último domingo, en la cual le 
pidió la renuncia a su ministerio, "ya que era lo que a mi me parece conveniente, después que todos los demás ministros han renunciado y él sigue siendo una figura (que) entorpece la credibilidad del proceso..." (10 de enero de 1980). Esta conversación se prolongó por unas 2 horas. Como se verá en la segunda parte, Monseñor desconfió de las intenciones de este general desde el comienzo de la gestion de la primera junta por sus vínculos con el pasado, con el régimen del general Romero.

\section{La oligarquía}

La oligarquía a través de diversos representantes, individual y colectivamente, dialogó con Monseñor, quien mantuvo siempre abiertas las puertas, aún sabiendo que no lo aceptaban y que lo atacaban siempre que podian. Sin embargo, Monseñor mantuvo su apertura fundamental y aprovechó estos encuentros para tratar de aclarar los malos entendidos sobre su actuación y, al mismo tiempo, intentó iluminar con las luces del evangelio y la doctrina social de la Iglesia.

Así, un cañero sintió la necesidad de explicarle personalmente su presupuesto de gastos para concluir que el aumento de los salarios pedido por los trabajadores era imposible, "tuve la impresión," comentó más tarde Monseñor, "de que traía sus juicios formados y de que poco servía un diálogo. Como yo lo indiqué comprendia las necesidades de los cañeros, pero también había que comprender las necesidades apremiantes de los colaboradores campesinos y que habia que buscar soluciones inteligentes" (20 de octubre de 1978).

Un capitalista importante le habló de la difícil situación en su fábrica de gaseosas La Constancia el 28 de junio de 1979. El 5 de julio se volvieron a ver, esta vez con todos los directivos de la empresa. Fue una "interesantísima reunión intima," en al cual discutieron el problema de las relaciones patronales y laborales desde la doctrina social de la Iglesia. "Tengo la impresión de que este acercamiento será de gran trascendencia, de gente capitalista a la Iglesia, en búsqueda de soluciones cristianas para la situación social del pais," apuntó Monseñor después en el diario (5 de julio de 1979). A comienzos de marzo de ese año en esta fábrica hubo un conflicto laboral de grandes proporciones, el cual se resolvió, en parte, gracias a la intervención de Monseñor y el arzobispado.

En agosto de ese mismo año se entrevistó con otros dos grandes industriales, quienes estaban muy preocupados por la situación del pais y querían compartir estas preocupaciones con el arzobispo: "según ellos, la Iglesia es la única que tiene una voz moral... Aunque no en todo estamos de acuerdo, creo que aceptan la dura exigencia del evangelio de que sólo se puede hacer una verdadera paz si se hace una verdadera justicia..." comentó Monseñor (28 de agosto de 1979).

Monseñor siempre estuvo dispuesto a mediar en los secuestros de capitalistas como Jaime Hill y el industrial japonés Matsumoto, poniendo todo su interés personal para salvarles las vidas y resolver el secuestro lo más rápidamente posible. Atendia y consolaba a las familias de los secuestrados (16 y 19 
de enero y 18 de marzo de 1980). En el último caso, le impresionó mucho el encuentro con la señora de Matsumoto, quien le pidió "que aunque no era cristiana, quería hacer una oración conmigo por su esposo." Juntos se dirigieron a la capilla del hospitalito y rezaron de rodillas delante del Santisimo ( 3 de julio de 1978). Esta disponibilidad para servir la extendió incluso a los casos más pequeños, como cuando lo visitó un ingeniero para pedirle mediar con las $\mathrm{Li}$ gas Populares, las cuales le habían tomado su oficina (11 de febrero de 1980).

Dentro de sus diálogos con este sector de la sociedad salvadoreña, se destacan dos, uno de ellos con los llamados empresarios jóvenes y el otro más formal con la Asociación Nacional de la Empresa Privada (ANEP) y el partido demócrata cristiano. El primer diálogo lo estableció por medio de un joven empresario, quien buscó al arzobispo para exponerle sus inquietudes sociales (26 de febrero de 1979). Este joven empresario organizó varios encuentros entre sus colegas y Monseñor. La evaluación de estas reuniones por parte de Monseñor fue siempre positiva, "... los invité a que expusieran todo lo que tuvieran contra la Iglesia. A fin de desahogar cualquier resentimiento, cualquier aire de separacion y fueron muy francos. Nos dio la oportunidad de defender la posición de la lglesia y al mismo tiempo of recerles que en aquellas cosas en que ellos tuvieran razón, estábamos dispuestos a aceptar la verdad" (2 de marzo de 1979). Como pedian orientación y apoyo, explicaba Monseñor, se lo dio con mucho gusto (11 de enero de 1980).

El otro diálogo, promovido por Monseñor y en el cual no participó personalmente, sino a través de sus asesores en quienes delegó, fue entre el partido demócrata cristiano, la ANEP y los representantes de la Iglesia. Su primera impresión fue que "se muestra voluntad de dialogar, pero se nota también mucho apego a sus propias ventajas. Sin embargo, la tarde fue muy útil, hubo bastante cambio de impresiones y se continuarán estos diálogos" (6 de diciembre de 1978). Pese a su ausencia personal, Monseñor siempre estuvo siguiendo de cerca la marcha de estas conversaciones a través de sus representantes y siempre los animó a seguir con la esperanza firme de lograr algún entendimiento, no obstante el aparente estancamiento de las conversaciones. En efecto, cuando el diálogo se estancó "por falta de sinceridad y... mucho interés de grupo," Monseñor, después de discutirlo con sus asesores, concluyó "que siempre era conveniente participar y aprovechar para iluminar desde la Iglesia los caminos de nuestra situación" ( 22 y 23 de mayo de 1979). Evaluando estas conversaciones 3 meses más tarde, Monseñor comentó que había "un progreso en la mutua comprensión y que la Iglesia ha tenido oportunidad de aclarar varios malos entendidos y que se va caminando positivamente hacia mejores conocimientos y más amplios horizontes en favor de la solución de la crisis" (23 de agosto de 1979).

En una cena con dos industriales jóvenes, varios demócrata cristianos y ministros de la primera junta de gobierno tuvo "una conversación muy rica en experiencias, de criterios bastante abiertos. Me dio la impresion de que en el mundo empresarial hay también mentes muy cultivadas y muy sensibles a la cuestion social. Por mi parte, creo haber expresado entre ellos el pensamiento genuino de la Iglesia y un llamamiento a la clase pudiente para que facilitara el cambio que nuestro pueblo necesita" (23 de octubre de 1979). 
Monseñor no desperdiciaba estos encuentros informales para predicar, oír y aprender. Comentando un almuerzo con un grupo de sef̂oras de la exclusiva colonia San Benito, dijo "hubo oportunidad de compartir criterios y me dio satisfacción la inquietud espiritual que ha despertado la predicación de la Iglesia actual. Creo que es una oportunidad magnifica para evangelizar a este sector tan dificil de la diócesis. Y a través de un grupo de sef̂oras evangelizadas y de buena voluntad ... siento que puede llevarse la Palabra de Dios a muchos otros hogares"' (13 de marzo de 1979).

Con el mismo espíritu de diálogo recibía a sus críticos y detractores a quienes primero escuchaba con atención y respetuosamente y luego reconocía lo que le parecía acertado, pero también reaccionaba dejando claro su mensaje de pastor. A una persona que acababa de escribir en su contra campos pagados y quien llegó a verlo, en "misión de sondeo" por parte del gobierno y de "los poderosos grupos económicos," le traló de explicar "lo que es la misión de la Iglesia que señala dónde está la raiz de tantos males y que no es ella la culpable" (20 de abril de 1978).

A un doctor amigo personal le suplicó que siempre que quisiera decirle algo lo hiciera con toda confianza. La súplica se la hizo cuando el doctor en cuestión llegó a decirle que aclarara ante los amigos y los enemigos que lo escuchaban que no confundía terrorismo con reivindicaciones justas y que en la llamada izquierda había muchas reivindicaciones justas. Lo condenable, para el interlocutor, era la violencia fanática y el terrorismo. Monseñor, entonces, completó "el concepto diciendo que igualmente me gustaria distinguir en la derecha también algo bueno que hay, de lo malo que también hay" (29 de marzo de 1979).

En este espíritu de apertura, Monseñor aceptó invitaciones a comer cuando sabía que en la conversación saldrían críticas a su actuación y a su predicación. Comentando después una de estas comidas dijo "una conversación muy interesante, aunque me parece muy inclinada al capitalismo (la familia anfitrión), incluso con críticas a la acción actual de la Iglesia, pero en forma siempre respetuosa" (10 de agosto de 1979). En otra ocasión oyó los comentarios de otro doctor quien decía haber encontrado ilogicidades en su última carta pastoral sobre las organizaciones populares. Monseñor respondió a sus objeciones en su programa radial de los miércoles.

Otras veces estos encuentros con sus críticos eran tensos y poco respetuosos. Saliendo de una celebración litúrgica en un colegio muy exclusivo en Santa Tecla, "tuve el desagrado de encontrarme con una señora que dijo que yo no era el mismo de antes y que les había defraudado. No quise comentar absolutamente nada. Y comprendo que esta calumnia es generalizada en todos aquellos que no quisieran que la Iglesia locara sus mezquinos intereses"' (21 de agosto de 1979).

\section{Las organizaciones populares}

De la misma manera que Monseñor estaba abierto a los sectores sociales anteriores, también estaba accesible para las organizaciones populares y los 
grupos político-militares. Con todos ellos mantuvo conversaciones y tuvo contacto constante. Estos encuentros por lo general tenían lugar en la noche, en su residencia; y así como los otros no llegaban solos, él tampoco los recibia solo, siempre con algún asesor por lo menos. Estas conversaciones, pese a las apariencias, fueron dificiles, aunque no por ello no menos ricas y satisfactorias para un pastor que se consideraba pastor de todos los salvadoreños por igual. Por lo general, en estas conversaciones los organizados le informaban de sus actividades, le explicaban sus análisis políticos y le preguntaban con igual interés por el papel de la Iglesia. Uno de los temas del momento era la ocupación de los templos.

Monseñor constató varias veces que en las tomas de los templos "no habia mala voluntad contra la Iglesia, sino que se valían únicamente de este medio, para hacerse oir y que me pedian disculpas" (1 de junio de 1979); así se lo explicó en una ocasión una delegación del FAPU. En efecto, uno de los aspectos que más parece en el diario en cuanto a la relación de Monseñor con las diversas organizaciones populares es la repetida y constante toma de los templos de la capital. Al comienzo del diario, el 14 de abril de 1978, Monseñor relata con detalles la ocupación de la catedral por los miembros del Bloque Popular Revolucionario (BPR) y su propia intervención. Según su testimonio estaba preocupado por la ocupación de su catedral porque la situación de la gente encerrada era grave, no había alimentos y los cuerpos de seguridad rodeaban amenazadoramente el templo.

Cuando le pidieron intervenir directamente se presentó en la catedral con su obispo auxiliar, pero el oficial al mando del operativo no los dejó pasar, y los mantuvo bajo el sol media hora, hasta que Monseñor se cansó y se retiró. Al pasar enfrente de la casa del párroco de la catedral quiso entrar para saludarlo, pero también se lo impidieron. Sólo pudo hablar con él por teléfono. En la noche, por fin le permitieron pasar a través del cerco de los cuerpos de seguridad y entró a la casa parroquial y a la catedral. Constató que todo estaba en orden y que no había novedad, pero aprovechó que ya estaba ahi para dar orientaciones cristianas a los encerrados, llamándolos a la verdadera liberacion, la del pecado, y a un amor a Jesucristo que excluía resentimientos, odios y toda frase disonante. En seguida platicó con los dirigentes de la ocupación con quienes compartió la información que tenía sobre la marcha de las negociaciones. En el diario, Monseñor anotó lo siguiente "...no hay mal espíritu contra la Iglesia, pero que tampoco les interesan mucho los intereses de la Iglesia en cuanto a su celebración del domingo y que prefieren sus intereses del grupo de organizacion que tienen" (14 de abril de 1978).

Los responsables de la ocupación, sin embargo, le pidieron que les dijera una misa al dia siguiente, lo cual aceptó Monseñor. Al salir, el coronel responsable del operativo de seguridad le reclamó el largo rato que habia permanecido dentro. Monseñor le respondió, "no tiene nada de extraño, ya que estábamos en nuestra propia casa." A continuación se ofreció a darle protección para garantizar su seguridad personal, lo cual Monseñor comentó en su diario de la forma siguiente, "noté que era una exageración de esas que se usan para justificar muchas acciones militares (14 de abril de 1978). 
El 18 de abril, después de largas negociaciones entre los embajadores de las sedes diplomáticas ocupadas por el BPR, el gobierno y los asesores del arzobispado, el BPR desocupó la catedral "con bastante desorganización" al faltar medios de transporte para trasladar a sus ocupantes a sus lugares de or $\mathrm{j}$ gen, "yo temo por ellos; las represalias que puede haber en el camino o al llegar a sus cantones. ¡Dios quiera que no!" (18 de abril de 1978). Pero a las ocho de la mañana de ese mismo dia, el FAPU dio comienzo a una nueva ocupación, esta vez, de la Iglesia El Calvario. Monseñor fue a dialogar con los responsables para conocer sus objetivos e intenciones. Estos querian la colaboración del arzobispado para piotestar por los atropellos en la zona de Suchitoto, a donde se había extendido la represión gubernamental, después de haber atacado la región de San Pedro Perulapán.

Las ocupaciones se prolongaron después de los sucesos sangrientos del 8 de mayo de 1979 en el centro de San Salvador y en las gradas de la catedral. El BPR "se empeñó" en exigir al gobierno la libertad de tres compañeros capturados, pero que el gobierno del general Romero aseguraba no tenerlos. El 18 de mayo, al regresar de su segundo viaje a Roma, Monseñor intervino haciendo un llamado público en el cual pidió "al Bloque que ponga término a estas ocupaciones y que de los desaparecidos ya todo el mundo sospecha lo fatal y que es suficiente haber presionado al gobierno. De otra manera, el Bloque también está contribuyendo grandernente al malestar del país que no compensa al objetivo de sus peticiones" (18 de mayo de 1979). A las personas afectadas por las ocupaciones les pidió acompañarlo a él también "en ese sentimiento de impotencia ante el capricho de los hombres." Personalmente Monseñor dijo que la toma de la catedral no le molestaba, "pero es también un sentido de impotencia no poderla rescatar y dedicarla al culto como se debe."

A finales de mayo, después de tres semanas de ocupacion, el BPR desalojó la catedral aprovechando el sepelio de los asesinados en los alrededores de la embajada de Venezuela. Monseñor comentó este hecho diciendo que "no es hora de mostrar quién es más fuerte, quién vence, sino quién es más humano y es capaz de ceder y perdonar, para que no sigan lamentándose tragedias en los diversos ambientes del pais" (24 de mayo de 1979).

El 20 de diciembre de 1979, mientras las Ligas Populares ocupaban el arzobispado, el párroco de catedral avisó que el BPR se había vuelto a tomar el templo y que tenían con ellos un muerto.

La tolerancia de Monseflor respecto a estas actividades de las organizaciones y el apoyo explícito que les prestaban algunos miembros del clero, puso en peligro, según Monseñor, la autonomía de la Iglesia. Un problema que le preocupó mucho durante su arzobispado como iremos viendo. Ciertamente, para muchos "la tolerancia" de Monseñor hacia las acciones de estas organizaciones implicaba una confusión inaceptable entre la Iglesia y las realidades políticas. Pero Monseñor tenía claro que ni la Iglesia ni él mismo eran especialistas en politica, sin embargo, guardando siempre su autonomía y respetando la responsabilidad de los laicos, de los partidos políticos y de las organizaciones siempre, como Iglesia, tenía una palabra para decir "para apoyar lo justo y reprobar lo injusto" (7 de junio de 1979). Así, en el diario queda claro 
como Monseffor luchó para que no se confundieran ambas cosas, ni en la realidad ni en las apariencias públicas. El 12 de mayo de 1979, por ejemplo, estando la catedral tomada por el Bloque Popular Revolucionario (BPR), llegaron dos representantes de la organización a pedirle una misa por cuatro nuevos muertos, pero les respondió negativamente. No podia celebrar libremente en su catedral y sí se lo permitirian para celebrar los difuntos de una organización. A cambio les propuso celebrar la misa en la basílica para no dar la impresión de estar subordinado al BPR, lo cual le aceptaron. Luego comentó en el diario, "creo que se ha resuelto uno de esos problemas inesperados, que son dificiles de solución por las complicaciones que puede tener" (12 de mayo de 1979).

Cuando los del FAPU le llegaron a proponer ayuda a la Iglesia, "les advertí mucho su peligro de manipular. Ellos estuvieron de acuerdo... porque respetando su autonomia, su independencia de toda agrupación política comprenden que la Iglesia es gran orientadora y estímulo para la lucha liberadora del pueblo. Insistí mucho en esa autonomía de la Iglesia y cómo la Iglesia desde su perspectiva evangélica está de acuerdo y apoya todas las iniciativas que tengan como objeto la justicia, el bienestar y la paz de los hombres" (12 de junio de 1978). A los dirigentes del BPR les pidió no confundir los fines de la Iglesia, aunque ésta los apoyara "ro precisamente por ser Bloque Popular Revolucionario, sino porque ella, desde una perspectiva cotidiana, de buen samaritano, ha procurado ayudar a todo necesitado de cualquier color que sea y que en este sentido se les suplicaba mantener $y$ hacer mantener entre sus adeptos el respeto hacia la autonomia de la Iglesia y que de ninguna manera fueran a utilizarla para sus fines" (12 de abril de 1978). En todas estas entrevistas, Monsenor, aparte de exponer su pensamiento y criticar constructivamente la vida pública de los organizados, trataba de encontrar en ellos "io que interesa para la misión de la Iglesia"' (15 de enero de 1980).

La ocupación de los templos preocupó bastante a Monseñor. Evaluando los sucesos de mayo de 1979, preguntó a sus asesores durante un desayuno realizado el 23 de mayo sobre qué relación mantener con el BPR, organización que habia mostrado poco respeto por la Iglesia al tomarse los templos y se había expresado contra el arzobispo. Sus asesores le aconsejaron no romper relaciones, "aunque hubiera un momento dificil en su defensa de los derechos del pueblo y que habia que esperar para decidir estas relaciones..." (23 de mayo de 1979).

Ese mismo día, al conocer el asesinato del ministro de educación del general Romero, el cual fue interpretado como una venganza por los 14 manifestantes asesinados en las cercanías de la embajada de Venezuela el día anterior, Monseñor hizo otro llamado público expresando "su solidaridad con el sufrimiento de tantas familias y oración por los difuritos y un llamamiento en que no se encaprichen en sus conflictos al gobierno y el Bloque. $Y$ haciendo un llamamiento a quienes pueden interceder para que esto se arregle pronto, ya que está costando muchas vidas y mucho malestar a nuestro pueblo" (23 de mayo de 1979). Al preparar su entrevista de los miércoles para la YSAX, la radio del arzobispado, desarrollo este mismo tema invitando a las dos partes enfrentadas a la reconciliación. 
El 19 de septiembre de 1979, Monseñor convocó a una reunión para estudiar los criterios y las actitudes a tomar frente a las tomas de los templos. A esta reunión invitó a Monseñor Rivera, como un especialista en derecho canónico. De la reunión se concluyó que, en tiempos normales estas ocupaciones eran profanaciones que el derecho sancionaba y que producian mal entre los cristianos. "Pero la situación es anormal. Así como Cristo dijo que no es el hombre para el sábado... y así como en las circunstancias anormales se permitió comer los panes de la proposición, asi la ocupación de los templos cuando se han cerrado los cauces de expresión es un mal menor" (19 de septiembre de 1979). Los reunidos acordaron también cerrar sin publicidad por un tiempo la catedral, el Calvario y el Rosario, los templos más apetecidos por las organizaciones. Pero, a mediados de febrero de 1980, volvieron las tomas y las dificultades pastorales. El 18 de febrero, Monseñor reunió al senado para tratar el asunto; discutieron bastante sobre la oportunidad de emitir un documento, "pero se creyó más oportuno una acción directa con los que causan las ocupaciones y así se encargó a aquellos sacerdotes que tienen más contacto con las organizaciones para que procuraran que la dirigencia de dichas agrupaciones se entendiera en diálogo conmigo, a fin de platicar la manera de que estas ocupaciones no se realicen más o en caso de extrema necesidad, se haga siempre de acuerdo con el responsable de los templos"' (18 de febrero de 1980).

A finales de rebrero, en el diario, Monseñor expresa una actitud más comprensiva hacia estas actividades de las organizaciones populares, "el inconveniente de las ocupaciones es grave, pero comprendemos que nuestro pueblo necesita estos refugios de la Iglesia ante las situaciones de opresión tan horrorosa que estamos viviendo" (24 de febrero de 1980). Dias antes, habia conversado, el 16 de febrero, con los dirigentes de una nueva toma de la catedral, dos jóvenes del BPR, "cristianos, pero que se sienten obligados a hacer estas acciones ya que no encuentran seguridad fuera de la Iglesia" (16 de febrero de 1980 ).

En otras ocasiones las visitas nocturnas tenían como objetivo clarificar los criterios y aclarar las divergencias no sólo sobre las tomas de los templos, sino además sobre las relaciones de las organizaciones con las comunidades de base eclesiales y sus criticas a la pastoral de la arquidiocesis. Monseñor no tuvo miedo a entrar en estos temas con los organizados, para él estas conversaciones, según el testimonio del diario, siempre resultaron muy interesantes $y$ enriquecedoras, aunque no dejó de anotar la dificultad de dialogar cuando las posturas políticas ya estaban tomadas firmemente (17 y 26 de junio de 1979).

Después del golpe militar del 15 de octubre, el diálogo con las organizaciones populares se volvió particularmente dificiT, excepto con eI FAPU. Monseñor quería que al menos dieran una oportunidad a la primera junta para consolidarse y ver qué podía hacer respecto a sus proyectos reformistas. Monsefior vio con mucha esperanza una alternativa real viable en la realización de los propósitos de la proclama del 15 de octubre de 1979. No es que creyera que ella iba a resolver de modo global todos los problemas existentes, pero para él alternativa real implicaba un buen proyecto para comenzar a alejarse del proyecto represivo del general Romero. 
La postura, a veces dura, de Monseñor frente a la intransigencia de las organizaciones populares después del 15 de octubre, durante la gestión de la primera junta, estuvo fundamentada en la siguiente perspectiva, "...comprendi que tanto la junta de gobierno como las organizaciones populares que están hoy en pugna con el gobierno, tienen sus puntos positivos y también sus puntos negativos. Y desde allí la posición de la Iglesia de animar lo bueno, de apoyarlo, tanto en la junta como en las organizaciones. Como también por el amor a la patria y por el bien de la justicia, reclamar contra aquellas cosas que estorban este proceso revolucionario que parece se ha iniciado. De todos modos, sentimos que hay algo nuevo y que tenemos que estar muy atentos a los signos de los tiempos" (9 de octubre de 1979).

Las Ligas Populares se mantuvieron instransigentes, negándose a dialogar con las nuevas autoridades y haciendo un llamado inmediato a la insurrección popular. Monseñor, por su parte, estaba en capacidad de patrocinar un diálogo entre la organización y el gobierno. Los representantes de las Ligas le respondieron que deberían consultarlo con su dirigencia, pero que de todos modos creían que el diálogo no era conducente "porque esta junta es nada más que un estorbo al proceso de insurrección del pueblo. Traté de hacerlos comprender, pero son muy obstinados" (22 de octubre de 1979).

El 1 de noviembre de 1979 dialogb con los representantes del BPR "con quienes comparti mis opiniones, distintas naturalmente de ellos... y aproveché para pedirles una pronta resolución de las ocupaciones... Ellos son muy dogmáticos en sus modos y es dificil dialogar cuando ya se traen ideas fijas. Sin embargo, traté de ser lo más amable, a fin de dejar abierta la posibilidad de diálogo con ellos" (1 de noviembre de 1979).

A través de la YSAX, Monseñor condenó la ocupación de la catedral y de los dos ministerios, "reprobé los actos de violencia y me alegré de la libertad de los rehenes, pero con ese mismo derecho a la libertad, pedi que todos fueran rescatados a la libertad muy pronto... la ocupación de templos, ministerios y otros escándalos no son constructivos sobre todo cuando se está haciendo un llamamiento al diálogo. Invité a la creatividad política, a aprender el lenguaje político en vez del lenguaje violento, ya que hoy es un momento muy peligroso para usar la violencia en este ambiente tan explosivo y, en cambio, es muy constructivo expresar en un pluralismo legítimo las opiniones de los diversos sectores del pueblo. Abogué nuevamente por la paz y por un camino más racional hacia la justicia y hacia la paz" (29 de octubre de 1979).

Con el FAPU las cosas aparentemente eran más fáciles. El 7 de noviembre tuvo una entrevista con sus dirigentes quienes se quejaron de ciertos comentarios de la YSAX los cuales, según ellos, no distinguian bien entre unos y otros grupos. "Se aclararon mucho las cosas, mal entendidos, y se les ofreció que cuando tuvieran algo que aclarar que con gusto les reproduciríamos sus aclaraciones, toda vez que correspondieran a la verdad y fueran siempre criterios positivos para la construcción del bien común del país" (7 de noviembre de 1979).

Con las otras organizaciones mejoraron las relaciones al final de su arzobispado, cuando la democracia cristiana llegó al poder en la segunda junta y 
cuando Monseñor se distanció públicamente de su proyecto reformista a causa de la represión incontenible. A principios de enero de 1980, por la noche, el diario dice que tuvo otra conversación más positiva con miembros del BPR sobre su análisis de la situación del país y notó "un cambio bastante grande en su apertura al diálogo con las otras organizaciones, incluso esta invitación que hacen a la Iglesia, la cual aprovechamos para inspirar el seguimiento pastoral que queremos hacer a todos aquellos cristianos que se incorporan a estas organizaciones políticas populares, a fin de que se salvaguarde la fe de esta gente en estas militancias. Para mi fue esperanzador este diálogo que quedamos de acuerdo en continuar haciendo" (6 de enero de 1980).

El 21 de febrero de 1980, "entrada la noche", se entrevistó con un miembro de las Fuerzas Populares de Liberación (FPL), "Tuerza clandestina que es muy temida entre nosotros, causa de varios secuestros, pero con los cuales he podido entrar en diálogo con el objeto de expresar el sentimiento y los pensamientos de la Iglesia y hacer comprender que el respeto de estos sentimientos cristianos de la mayoría del pueblo, serán una condición para que ellos puedan disfrutar la popularidad de que carecen cuando atropellan estos sentimientos." Monseñor tenía conciencia que por medio de estos delegados o representantes su "mensaje... llega también a toda la organización desde su dirigencia" (14 de febrero de 1980).

El 20 de febrero de 1980 ya había logrado concertar un encuentro entre la coordinadora nacional de las organizaciones populares y los militares, pero éstos no se presentaron, "sin embargo, el contacto con las dirigencas de las organizaciones resultó muy fructuoso, aunque no profundizamos en aspecto concreto alguno.." (20 de febrero de 1980). Acordaron continuar hablando sobre la ocupación de los templos, esta vez con los párrocos afectados. En este ambiente se llevó a cabo la segunda reunión programada con los párrocos, quienes expusieron sus inconvenientes, mientras que las organizaciones explicaron por qué se tomaban los templos. Discutieron cómo llegar a un acuerdo para no hacer mal y conseguir la eficacia "que las organizaciones dicen poner a estas tácticas de presión, de defensa, de denuncia" (21 de Tebrero de 1980).

Pese a todas las dificultades, incluso con los grupos más difíciles, Monsefor admiraba a los organizados "cómo tienen capacidad de análisis y tienen ideas políticas muy claras" (15 de enero de 1980).

Sobre estos y otros contactos guardo mucha discreción. En el diario hay pocos detalles en cuanto a identificar por nombre a sus interlocutores. En cierta ocasión, el FAPU le pidió informes sobre un detenido quien se había fugado de las cárceles clandestinas y a quien él había dado amparo, pero "traté de evadir para conservar el secreto, de lo cual se podrá hablar después" cuando ya esté en sitio más seguro (5 de octubre de 1978).

Como ya se ha indicado antes, según el diario, Monseñor era llamado a mediar entre las organizaciones y el gobierno de turno. Aquí indicamos algunas de sus mediaciones, pedidas por las organizaciones. El 30 de diciembre de 1978, las Fuerzas Armadas de la Resistencia Nacional (FARN) pidieron expresamente su participación, la cual aceptó, "para ayudar a salvar esas vidas y también las vidas de los prisioneros que estas fuerzas le piden al gobierno." 
Durante la primera junta, las Ligas Populares que se habian tomado el templo del Rosario y habian capturado a un guardia nacional, aceptaron en primera instancia entregar el guardia a Monseñor, pero después cambiaron de opinión decidiendo entregarlo al fiscal de la República, lo cual enfureció más a los cuerpos de seguridad que presionaban el exterior del templo, "hasta me dijeron palabras bastantes fuertes y se notaba que no tenian paciencia," observó Monseñor. Hecha la entrega del guardia, la Policía Nacional dijo que habia 2 policías detenidos dentro y que investigaría; Monseñor logró negociar un cateo del interior del templo en su presencia. Al final, se quedó a dormir en el convento con los otros intermediarios. Cuando al dia siguiente ( 2 de noviembre) lo llamaron de casa presidencial para agradecerle la intervención aprovechó la llamada "para describir cómo veía yo la situación en los cuerpos de seguridad, unos je「es que si son educados y que quieren tranquilidad, pero unos agentes que pueden insubordinarse y que en un momento de desobediencia pueden ser fatales" (1 y 2 de noviembre de 1979).

Dos dias más tarde, comentó los sucesos de esa noche con los representanles de las Ligas y "aclaré varias situaciones... los invité a abrirse a la capacidad de diálogo y de colaboración, pero ellos están bastante aferrados a sus principios y es difícil que esta gente admita el diálogo de colaboración por el bien común de la patria, quieren hacer prevalecer únicamente sus criterios de organización"' (3 de noviembre de 1979).

El 16 de febrero de 1980 intervino personalmente en un conflicto laboral en el cual estaban involucrados el BPR y el FAPU. Ambas organizaciones se estaban estorbando mutuamente en una fábrica cerrada y en proceso de ser reabierta.

Cuando medió en los secuestros no dejaba pasar la oportunidad de entrevistarse con los representantes de las organizaciones "para iluminar con el evangelio las actividades que no concuerdan muchas veces con el sentir cristiano"' (14 de febrero de 1980).

Monseñor pidió expresamente a los organizados formular cuanto antes un proyecto de gobierno "que salga del pueblo y que se presenta al pueblo para aglutinar al pueblo en estas organizaciones" (14 de febrero de 1980). Dentro de ese proyecto, Monseñor vio que la Iglesia podia jugar un doble papel de servicio: iluminar las áreas técnicas que no eran de su competencia desde el evangelio y velar por los intereses religiosos y humanos del pueblo. Deseaba que este proyecto fuera dado a conocer pronto y muy concretamente para que el pueblo tomara conciencia clara de qué pretendian las organizaciones frente a los otros proyectos de la oligarquía y de la democracia cristiana y Estados Unidos. El 26 de rebrero tuvo una reunión en el arzobispado con las organizaciones y "otros organismos politicos" para discutir este proyecto.

A niveles más personales, Monseñor dialogó con algunos miembros de las organizaciones político-militares. El 13 de marzo de 1979 dice que recibió a 2 jovenes "para tratar inquietudes de sus ideologias de violencia, de las cuales no quieren ceder, a pesar del esfuerzo que he hecho... creen que solo la violencia puede resolver las actuales injusticias." Días más tarde, el diario registra que tuvo otra conversaçión con 2 miembros de la 2 anassilla, sin especificar si 
eran los mismos de antes u otros diferentes. Monseñor dice que trató de mantener la idea cristiana de la no violencia, "pero esta gente está muy convencida de que no es la fuerza del amor la que arreglará la situación, sino la fuerza de la violencia ya que no se quiere atender a razones y mucho menos al amor cristiano. He sentido profundamente la diferencia de pensar entre un inmenso sector de nuestra patria, representado er. estos interlocutores y el sentir cristiano. Pido al Señor que ilumine los caminos de su Iglesia para que sean comprendidos aun por aquellos que buscan el bien de la patria, pero por caminos muy distintos de los que Cristo señaló" (26 de marzo de 1979).

El 26 de enero de 1980, en el diario hizo constar que habia conversado con un joven de "las agrupaciones clandestinas" sobre sus proyectos políticos. Monseñor aprovechó este encuentro, tal como lo había hecho con los otros, para expresar el sentir de la Iglesia acerca de las soluciones violentas, pero también sabia que "ellos tienen ya su ideologia y su modo de pensar y es dificil hacerlos cambiar. Creo que la oración por toda esta gente es la mejor manera de colaborar con ellos y de dar a la patria una solución que no esté basada sobre sangre y odio o violencia"' (26 de enero de 1980).

Este tema tan delicado lo trató asimismo en público con ocasión de la integración, también pública, del ex-ministro de educación de la primera junta de gobierno a las FPL. En una entrevista por radio "dice que, primero, era respetar su opción, desde luego, que la habrá tomado muy en conciencia y sacar las lecciones de esta opción, lo cual denuncia la cerrazón de la extrema derecha que no admite soluciones pacificas, sino medios violentos que propician estos grupos de izquierda y también la culpa del ejército que ha acostumbrado a reprimir las aspiraciones de un pueblo y el cual cree que no hay otra manera de defender, sino con la misma arma, la violencia." Monseñor expresó su deseo de que este caso hiciera pensar sobre el poco margen que iba quedando "para soluciones pacíficas racionales y que hay que urgir todos los que pueden hacer algo, para que esta solución pacífica y racional lleve adelante los cambios y no haya necesidad del baño de sangre que se ve venir" ( 8 de enero de 1980).

No obstante estas serias reservas sobre los métodos de las organizaciones populares y sobre sus ideologías y las dificultades concretas al momento de enfrentarse con ellas, Monseñor siempre estuvo dispuesto a hacer de buen samaritano. En este sentido, era también el pastor de los organizados, con sus dificultades claro está, pero no por ellas los desconoció. Sin distinguir tendencias politicas, ni interpretaciones, Monseñor, como pastor, estaba dispuesto a acoger y a proteger a todos los necesitados. Asi, después de la manifestación y de la masacre del 22 de enero de 1980, aparte de inciar una investigación independiente sobre lo sucedido para esclarecer los hechos presentados confusamente por el gobierno demócrata cristiano, Monseñor envió a sus colaboradores a tratar de ayudar "en esta tragedia, ayudando a evacuar la gente que estaba en catedral, unos 300 refugiados, que fueron llevados al arzobispado, donde se les proveyó de comida y dormida." Llamó a casa presidencial, al secretario de información, para pedir que no encadenaran las emisoras del país en una cadena nacional, "porque quitaban asi la espontaneidad y el pluralismo de la información." Debió insistir ante la respuesta negativa de casa presidencial, 
"quitando así toda iniciativa y toda participación a las diversas emisoras que habian estado prestando tan buen servicio social e informativo" ( 22 de enero de 1980).

Al dia siguiente, Monseñor volvió a llamar a casa presidencial para pedir se retirara el cerco militar a la Universidad Nacional, donde se habian refugiado miles de manifestantes. Primero le respondieron que el cerco habia sido puesto para proteger a los refugiados de las provocaciones de la derecha y Monseñor añadió en el diario, "que han sido los que originaron la tragedia desde ayer y que podian estar continuando sus ataques a los organizados cuando salieran de la Universidad." Insistió argumentando que para el pueblo era dificil comprender estas explicaciones gubernamentales. Entonces propuso la integración de una comisión que penetrara al recinto universitario a explicar a los refugiados la función del cerco y a calmarlos, pues ya se estaban amotinando (23 de enero de 1980). Finalmente, el gobierno retiró el cerco y los refugiados salieron pacificamente.

Por la tarde, Monseñor presidió la misa por los difuntos en la catedral y dirigió un mensaje de esperanza a la muchedumbre que rodeaba los ataúdes. "El entierro no se hizo esta tarde, sino hasta mañana por la mañana, cosa que me sorprendio, puesto que me habian invitado para la misa con motivo del entierro, pero así son estas organizaciones que tergiversan o desorientan las cosas para sus fines. De todas maneras la catedral estará prestando este servicio a los pobres" (23 de enero de 1980).

Estos actos de violencia comenzaron a provocar refugiados, es decir, población desplazada de sus lugares de origen. En abril de 1978, el arzobispado comenzó a recoger a esta población desplazada proveniente de la región de San Pedro Perulapán, donde la Fuerza Armada desató una campaña de terror contra la población civil. El criterio de Monseñor respecto a este fenómeno nuevo fue, "insistimos mucho, pues, en clarificar esta posición de la Iglesia que siempre tiene la obligación de amparar a los que son perseguidos y ser voz de los que no tienen voz, pero tratando de distinguir bien su misión netamente de la Iglesia de cualquier otro aspecto partidista, sobre todo, si tiene visos revolucionarios"' (12 de abril de 1978). Monseñor quería que ni unos ni otros manipularan o jugaran con la tragedia de los desplazados. A esto se deben sus advertencias y la disponibilidad de lá Iglesia para cualquiera que necesitara ser amparado.

En este sentido alegó que tampoco era excusa la existencia de desplazados para tomarse la catedral, tal como sucedió en febrero de 1980 . Esta vez, se trataba de mujeres y de nin̄os que comenzaron a llegar desplazados del departamento de Chalatenango, "donde los persiguen encarnizadamente." Monseñor dijo a los ocupantes de la catedral, quienes eran del BPR, que él comprendia la situación "y que la Iglesia estaba dispuesta a esta clase de hospitalidad y que no era necesaria la ocupación en la forma en que lo están haciendo. Y le expresé que me comunicara con la dirigencia del Bloque para hablar de la ocupación de templos, ya que comienza próximamente la cuaresma y el pueblo tiene derecho a estos lugares de oración..." (16 de febrero de 1980). En una palabra, Monseñor no quería ni multiplicar ni complicar "el trabajo por la caridad, si- 
no coordinar todos los esfuerzos, las iniciativas que nacen para el servicio del projimo..." (7 de marzo de 1980). Asi, pues, en esto también tuvo que "estar muy atento y trataremos de hacer una verdadera caridad al estilo de Iglesia..." ( 5 de marzo de 1980).

¿Qué buscaba Monseñor con todos estos diálogos y contactos con las organizaciones populares? Para él las organizaciones de masas y las organizaciones político-militares eran una fuerza social importante con la cual había que contar, pero además eran un principio de renovación del orden social y económico en el cual él puso muchas esperanzas, a pesar de sus limitaciones evidentes. Ellos también eran salvadoreños que querían el bien de las mayorías. Muchos de ellos eran, además, cristianos. Desde esta perspectiva, como pastor de todos, se trataba de "buscar entre todos, como verdaderos salvadoreños, la salida más pacífica y honrosa de esta crisis" (14 de febrero de 1980). En esta tarea, la Iglesia y él personalmente estaban dispuetos a prestar sus servicios y a defender siempre los intereses del pueblo desposeido. Monsenor se sentía muy salvadoreño y muy del pueblo. Pero para él, ser verdaderamente salvadoreño implicaba buscar incansablemente, manteniendo siempre la esperanza, una salida política racional, fundamentada en los principios del evangelio y en el bienestar de las mayorías. Y esa salida creyó encontrarla en el proyecto popular. En este sentido pidió a Dios "que no vaya a acelerarse esta violencia que se ve venir ya que la izquierda y los grupos políticos populares no ven otra salida para la verdadera transformación..." (6 de marzo de 1980).

\section{Los campesinos y los obreros}

Las organizaciones de campesinos y obreros visitaron a Monseñor para saludarlo, expresarle su solidaridad y pedirle apoyo para sus propias actividades y luchas reivindicativas. Así, en el diario se registraron entrevistas con la Confederación Unitaria de Trabajadores Salvadoreños (CUTS) varias veces; el sindicato de la Comisión Ejecutiva Hidroeléctrica del Río Lempa (CEL), el cual le pidió apoyo moral para sus reclamos sobre el fondo de jubilaciones (25 de mayo de 1978); los trabajadores en huelga de una lábrica de Santa Ana, quienes le contaron sus problemas y a quienes traló de ayudar según sus "luces" (27 de marzo de 1979 ; cuando fue a Santa Ana por otros motivos visitó la rábrica en huelga); dos obreros para invitarlo a enviar un representante a una reunión sobre los ideales obreros, la cual aceptó (1 de junio de 1979); la Federación Nacional Sindical de Trabajadores Salvadoreños (FENASTRAS) para pedirle una misa por una joven asesinada en La Reubicación, Chalatenango, pero les respondió que ya había aceptado decirla en la capilla del hospitalito. Al insistirle que la deseaban en un sitio más público para denunciar el crimen, respondió "que lo principal de la misa era la oración por el difunto y que ya denuncias se habian hecho en forma muy clara por parte de la Iglesia" (4 de junio de 1979); una central de !rabajadores ( 9 de noviembre de 1979); por último, una representación de organizaciones obreras de Holanda, Bélgica y Estados Unidos, acompañada de sindicalistas salvadoreños (13 de diciembre de 1979). 
Asimismo lo visitaron una central campesina no identificada pidiendo orientación para dar respuesta a la crisis el 30 de agosto de 1979 y otra o la misma el 25 de septiembre. El 12 de junio de 1979 participó en una reunión de la Unión Comunal Salvadoreña, y sus impresiones fueron las siguientes, "fue sumamente interesante platicar con estos campesinos de diversos puntos de la República sobre las inquietudes sociales. Admiré capacidad de autonomia y de respeto y de esperanza que tienen en la Iglesia. Les prometi toda la ayuda y seguir siendo fiel a las consignas de nuestra Iglesia latinaomericana, de la opción preferencial por los pobres..." El 19 de octubre de 1978 lo visitaron representantes de campesinos organizados para exponerle la situación de los trabajadores en las cortes de café y caña de azúcar y las subidas de salario propuestas al ministerio de trabajo. Monseñor comentó en el diario que consideró justas muchas de las demandas de los campesinos.

La Asociación Nacional de Educadores Salvadoreños (ANDES 21 de junio) lo visitó el 21 de abril de 1978 para pedir la libertad de varios maestros desaparecidos. Mientras que los trabajadores de la imprenta del arzobispado también llegaron varias veces a exponerle con mucha confianza sus problemas laborales. Monseñor prometió ayudarles y humanizar su situación (27 y 28 de junio de 1979).

Al igual que en sus diálogos con los otros sectores sociales, Monseñor aprovechaba estos encuentros con los obreros y los campesinos para enseñar $\mathrm{e}$ iluminar. A los obreros, por ejemplo, los invitó a mantener más diálogos para conocer mejor la doctrina social de la Iglesia, "espero que algo ha de ser atendido por los obreros, aunque a veces tienen otras ideologías" (21 de abril de 1978). Sin embargo, su invitación fue atendida por los obreros de la CUTS quienes volvieron a llegar con el propósito de discutir sobre ese tema el 28 de abril de 1978, "el diálogo a pesar de ser informal fue muy enriquecedor y desperló interés en los obreros."

La homilia en la misa de difuntos pedida por FENASTRAS la aprovechó "para apoyar lo justo de sus reuniones y de su reivindicación laboral, pero orientándoles a la trascendencia, de lo que nos habla ya la difunta Mercedes, que morir luchando por una causa en la tierra sólo tiene un sentido completo cuando no se han perdido las perspectivas de la eternidad. Y que un cristiano debe llevar para incorporar a la redención de Cristo todas las redenciones por las cuales trabajan esios grupos..." (6 de junio de 1979).

A los campesinos de la central que lo visitaron el 25 de septiembre de 1979 los exhortó "a mantenerse siempre idénticos, siempre como campesinos, como agrupación y les agradeci ese sentido de atención para la Iglesia, la cual a pesar de todas las calumnias, no tiene ninguna mala voluntad, sino el deseo de servir y orientar sinceramente según el evangelio"' (25 de septiembre de 1979).

En estas intervenciones a veces no era comprendido completamente. Por ejemplo, algunos de los obreros de FENASTRAS entendieron que Monseñor se oponia a las organizaciones, "aqui se ve cómo es dificil hacerse entender y por eso es fácil criticar a la Iglesia injustamente" (6 de junio de 1979).

Los obreros también se tomaron la catedral. Según el diario, el 13 de ene- 
ro de 1980 , los obreros de una fábrica en huelga se tomaron la catedral después de la misa dominical, "me indicaron que no se trataba de una ofensa a la Iglesia, sino de pedir una presión para poder dialogar con la parte patronal, que se niega, en esta huelga y que a fecta a muchos obreros y me pedian que hiciera yo el papel de mediador para acercar a los patronos a dialogar con ellos. Les ofrecí mis servicios, pero también les hablé de que no era conveniente esta actitud de tomarse el templo porque estorban el culto... sin embargo, ha seguido ocupada todo este día" (13 de enero de 1980). Una semana después, el 20 de enero, la catedral aún continuaba ocupada, pues no se habia podido dialogar con la parte patronal, pese a los esfuerzos del arzobispado para ello.

Monseñor participó personalmente o por medio de sus representantes o asesores en las negociaciones de varios conllictos laborales. En estas circunstancias trataban de ayudar hasta donde les era posible trabajar para que las partes en conflicto se sentaran a dialogar sus diferencias. La posibilidad de diálogo era siempre una esperanza en un ambiente tan dificil (10 de marzo de 1979). Estas negociaciones le llevaban días enteros como en el caso de La Constancia, ocurrido en marzo de 1979. Otro peligro que había que detener o evitar en estas ocasiones era la interferencia de los cuerpos de seguridad, los cuales estaban ansiosos por resolver los conflictos laborales militarmente, a pesar de que sus intervenciones producian más represión y dejaban muertos y heridos.

\section{Los esiudiantes}

El mundo estudiantil en todos su niveles también estuvo muy presente en el arzobispado. Una vez se trataba de un profesor con sus alumnos quienes llegaron a verlo para grabarle una entrevista sobre la misión de la Iglesia (11 de abril de 1978); otra vez era una delegación de una escuela para entregarle un donativo de 500 colones para hacer reparaciones en la YSAX, dañada por una bomba (29 de octubre de 1979) o de una escuela rural de un cantón de Cojutepeque que llegó a pedirle permiso para dar su nombre a dicha escuela, "yo les expuse mis dificultades y objeciones que podria proponer el gobierno. Sin embargo, me insistieron y con mucho agradecimiento les acepté..." (25 de mayo de 1978) o de un grupo de jóvenes de Sonzacate quienes querian que fuera a decirles una misa y a bendecirles una clínica, lo que rehusó por estar en otra diócesis, solamente aceptó cuando los estudiantes consiguieron el permiso del obispo de Santa Ana (15 de Tebrero de 1980). Aún así estuvo pensando sobre la conveniencia de ir para evitarse problemas con el obispo de aquella diócesis y porque el nuncio de Costa Rica había llegado a informarle de una nueva amenaza de muerte en contra de su vida, pero "senti un compromiso con esta juventud y fui y francamente fue una acogida muy cariñosa. Mi ausencia hubiera causado un gran desencanto y traté de llenar sus aspiraciones... Creo que aunque fuera de mi territorio, es Iglesia y es aliento a los esfuerzos de la humanidad" (22 de febrero de 1980).

El 26 de diciembre de 1978 un grupo de niños de San Antonio Los Ranchos invadió el arzobispado para platicarle "de sus ideales de querer sentir con los niños, compañeritos suyos, que han quedado huérfanos porque les han 
matado a sus padres o han desaparecido o están en prisiones. En esta navidad sienten ellos la tristeza de tantos niños y quieren colaborar."

Con frecuencia los colegios católicos y los nacionales, las escuelas técnicas y las vocacionales, de la arquidiócesis y de las otras diocesis, le dedicaron graduaciones y promociones a las cuales asistía sin decir a nadie que no. Cuando terminaban los cursos académicos lo vemos presidiendo estas ceremonias en todos lados. Con la directiva de la federación de colegios católicos mantuvo un contacto permanente y continuo a través de los cuales daba sus orientaciones según los principios pastorales de Medellín y Puebla que él trataba de aplicar en la arquidiócesis. Su preocupación era que los colegios católicos Iradicionales evangelizaran efectivamente y fuesen un instrumento más de toda la pastoral arquidiocesana, por eso "les llamé a superar diferencias, divisiones y a ponerse todos de acuerdo en una hora tan dificil en que la Iglesia no puede presentarse desunida" (22 de abril de 1978). La federación de estos colegios experimentó problemas serios con el obispo encargado de la educación por parte de la conferencia episcopal, Monseñor Aparicio, quien quería imponer sus propias ideas. Monseñor, en cambio, apoyó en todo a la directiva de la federación y les pidió expresamente trabajar para incluir dentro de la asociación a las escuelas parroquiales.

La Asociación General de Estudiantes Universitarios Salvadoreños (AGEUS) le pidio apoyo en sus reinvindicaciones universitarias el 9 de octubre de 1978 . Esta no fue la única conversación que tuvieron. Dos universitarios le llevaron una copia del informe sobre derechos humanos de la Organización de Estados Americanos (17 de abril de 1979). Además de recibir a los estudiantes universitarios, Monseñor estuvo oficialmente presente en la Universidad $\mathrm{Na-}$ cional tres veces, participando en tres mesas redondas. El 21 de febrero de 1979 lo visitaron el decano de la facultad de humanidades y sus colaboradores para invitarlo a dar una conferencia sobre la Iglesia en América Latina. Monseñor aceptó, pero propuso tener una mesa redonda en vez de la conferencia. Antes de ir, se preparó cuidadosamente estudiando y discutiendo con algunos de sus asesores. La mesa redonda se realizó el 27 de marzo en el auditorio de la facultad de derecho que rebasaba de universitarios. "La acogida que nuestra Universidad dio a esta representación de la Iglesia fue muy conmovedora... Hubo mucho respeto, mucho silencio en las exposiciones y después a la hora de las preguntas. Las preguntas también demostraron el profundo interés que el mensaje de la Iglesia representa para este ambiente universitario..." (27 de marzo de 1979).

El 14 de mayo lo invitaron por segunda vez a otra mesa redonda. Esta vez fueron los estudiantes de derecho. La mesa redonda tuvo lugar el 22 de mayo y tuvo como tema los derechos humanos. Monseñor fue acogido con calurosos aplausos por los estudiantes. Su comentario fue el siguiente, "le di gracias al Señor de poder llevar el mensaje de su Nombre a esta asamblea" (22 de mayo de 1979).

Más tarde, el 1 de junio llegó una representación de estudiantes de medicina a comentarle su asombro por la forma cómo se estaba aplicando la politica del control natal en los centros asistenciales. Aceptó participar en otra mesa re- 
donda en la universidad el día del estudiante de medicina. En ella presentó el tema desde la perspectiva de la Iglesia, habiéndose preparado cuidadosamente, de la misma forma en que lo hizo en los dos casos anteriores. A estas preparaciones y sesiones de estudio con sus asesores dedicaba una mañana o una tarde completa.

Los docentes de la Universidad Nacional y de la UCA lo visitaron para exponerle su plan de organizar un comité de docentes universitarios para defenderse de tantos atropellos. Entonces, aprovechando la ocasión, Monseñor los exhortó "a seguir cultivando sentimientos de solidaridad y aprovechó para transmitirles el pensamiento del Concilio acerca de la cultura y de la autonomía legítima de los valores temporales. Les pedi también una colaboración en el campo de la pastoral universitaria que tanto me preocupa..." (19 de abril de 1978).

Conversó con los rectores de ambas universidades sobre la realidad nacional y los problemas universitarios en diversas ocasiones. A mediados de mayo de 1979 se entrevistó con los dos rectores para coordinar actividades ante la situación planteada por la masacre del $\mathbf{8}$ de mayo en las gradas de la catedral y las subsecuentes ocupaciones. En otra ocasión fue a verlo el rector de la UCA para plantearle su preocupación por la ausencia de la Iglesia en el foro popular convocado por el gobierno para discutir la crisis del pais, "le dije que hay ausencias que son dolorosas, pero que son necesarias y que la ausencia a este foro en estas circunstancias no era negación de la buena voluntad de quienes sinceramente trabajan, sino pedir ambiente apropiado para colaborar con buena voluntad" ( 25 de mayo de 1979). El 23 de junio de 1979, Monseñor fue quien visito al rector de la Universidad Nacional para animarlo a no renunciar a su cargo y of recerle su apoyo moral "ya que su presencia es la gran esperanza para la Universidad." Aun cuando él personalmente estaba angustiado y abrumado por el deterioro de la situación, sabía dar esperanzas a los desanimados. En efecto, así lo hizo con el rector de la Universidad Nacional el 21 de agosto de 1979, "le dije que este simple hecho de preocuparnos y reunirnos era ya un signo de esperanza y que siguiéramos buscando, que de mi parte no podía dar ninguna luz de carácter técnico, pero sí como pastor animaba a la esperanza y excitaba que los entendidos colaboraran con sus conocimientos y sus experiencias" (21 de agosto de 1979).

\section{Las víctimas de la represión}

Según el diario, el 1 de octubre de 1978, Monseñor recibió a un desaparecido fugado de la cárcel, quien le "reveló cosas horrosas que pasan en ese misterio de las cárceles de los cuerpos de seguridad, donde sin duda hay varias personas que lamentamos como desaparecidas... una revelación verdaderamente horrorosa" (1 de octubre de 1978). El 10 de octubre recibió a "unos pobres obreros o campesinos," quienes llegaron a verlo desde La Unión, en el extremo oriental del pais, para enseñarle como había sido torturado uno de ellos. Ese mismo día llegó también un cursillista de cristiandad a contarle la desaparición de dos hijas universitarias. 
El 20 de febrero de 1979, "una reunion con personas que han sufrido en las cárceles y que milagrosamente han escapado y cuentan aquellas situaciones tan dificiles y la esperanza que les da la Iglesia cuando está en defensa del que sufre." El 3 de mayo llegó una familia a informarle de su hijo capturado, torturado y hospitalizado a quien más tarde Monseñor fue a visitar al hospital comprobando "una vez más qué poco respeto para el hombre en nuestra situación nacional." El 12 de junio llegó un doctor capturado y torturado, quien se puso a sus órdenes lleno de indignación ética; Monseñor comentó, "le admiré y agradeci porque este gesto de solidaridad en bien de la patria es para mi una palabra de mucho impulso." El 7 de julio lo visitó "una madre afligida" por la desaparición de su nuera. Al regresar a su residencia, el 21 de julio, se encontró con dos casos de represión, una familia que había llegado desde La Unión a "ponerme su lamentación" por haber perdido a un joven y la captura y desaparición del dueño de una imprenta de la capital. EL 30 de julio se fue a despedir un refugiado de "extrema izquierda," quien abandonaba el país, "lo que se ha hecho con él es una señal del tremendo irrespeto al hombre en nuestra patria." El 19 de septiembre toda una familia se le presentó llorando mientras le decian "venimos como hijos a un padre a decirle nuestros sentimientos porque nos han quemado un bus que era nuestro negocio, nuestra manera de vivir y hoy nos deja sumamente comprometidos económicamente. Les di palabras de aliento y me alegró que él es alcohólico anónimo... y les dije que tenían ellos el secreto de la solución en una gran fe, pero que al mismo tiempo, trabajaran porque Dios tendría que bendecirlos así como los estaba probando" (19 de septiembre de 1979). Con una queja similar llegaron varios grupos de personas afectadas por los actos violentos de "los grupos extremistas de izquierda" ante lo cual Monseñor comentó, sin duda desilusionado por la falta de comprensión de éstos hacia las posibilidades aún abiertas del 15 de octubre, "resulta así que la izquierda se ha vuelto más represiva que las represiones que estaba denunciando antes. Nos hemos solidarizado con todos estos obreros y trabajadores que han sufrido..." (16 de noviembre de 1979).

El 1 de febrero de 1980 llegó un seminarista cuya familia había sido víctima de la represión en La Unión. El 8 de mayo él visitó a la familia de un catequista asesinado en Chalatenango, "es también muy simpática esta gente, acoje con mucho cariño y se desvive por dar, participar de lo poco que tienen."

Así, pues, este breve recorrido de lo registrado en el diario indica que Monseñor vio el rostro de la represión y la violencia en las caras y en el sufrimiento de todas estas personas que lo visitaron buscando una palabra de consuelo y una voz de denuncia. Pero Monseñor no se quedó aqui. Consultó con abogados $y$ estudiantes de derecho sobre las dificultades que encontraba la Iglesia cuando le pedian ayuda jurídica en tantos casos de atropellos de los derechos humanos. El 31 de marzo de 1978 quedó constituido un grupo permanente de juristas que Monseñor considero importante "para tanto caso que llega de distintos órdenes" buscando justicia. De este grupo salió la sugerencia de presentar a la asamblea una petición de amnistía generál para los capturados en el caso de San Pedro Perulapán, donde se enfrentaron los campesinos organizados con ORDEN. También se sugirió ayudar al Socorro Jurídico con los 
casos ordinarios. Monseñor vio con mucha esperanza a este grupo. Asistió personalmente a la firma de la peticion de la amnistía y comento, "me dio mucho gusto que con esta ocasión abogados $\mathrm{y}$ estudiantes de derecho que estrecharon más su deseo de mantenerse unidos, de reunirse frecuentemente, de estudiar juntos asuntos juridicos y apoyar las necesidades de nuestro pueblo principalmente de los pobres" (5 de abril de 1978). Otra tarea que dejaron para más tarde fue un estudio sobre la inconstitucionalidad de la ley del orden público del general Romero (5 de abril de 1978).

Su apoyo y seguimiento a las labores del Socorro Jurídico y de la comisión de derechos humanos fue constante. Esto lo llevo asimismo a recibir delegaciones de instituciones y grupos internacionales dedicados a la defensa de los derechos humanos como la Cruz Roja Internacional, representantes franceses de organismos defensores de los derechos humanos (mayo de 1979), una comisión de abogados franceses (mayo de 1979), el Movimiento de Reconciliación Internacional con sede en Viena, la Comisión de Justicia y Paz de Estados Unidos (julio de 1979), una organización contra la tortura con sede en Milán (febrero de 1980), etc.

\section{Eclesiásticos, agencias y otros}

En este apartado final queremos presentar toda una serie de visitas del sector eclesiástico que se salieron del quehacer pastoral ordinario del arzobispo. Por estas visitas ordinarias entendemos las de los sacerdotes a quienes daba preferencia todos los lunes, "siempre llegan y me da mucho gusto platicar con ellos con mucha confianza" (24 de abril de 1978), religiosos y religiosas y sus respectivos superiores y superioras generales y regionales, con obras o sin ellas en la arquidiócesis.

Mención aparte amerita un grupo de sacerdotes de San Vicente suspendidos por su obispo, quienes le llegaron a pedir apoyo ante las congregaciones romanas, "naturalmente, yo les of reci hacer con caridad fraterna todo lo que esté a mi alcance en esta penosa situación" (14 de junio de 1978). A mediados de septiembre de 1979 renovó su ofrecimiento cuando "su propio obispo en la homilia del domingo recién pasado los desampara y casi los acusa de una línea peligrosa que es muy perseguida por el gobierno"' (14 de septiembre de 1979).

El curioso espectro de visitantes no ordinarios en la curia iba desde unos estudiantes de filosofia franciscanos quienes le hicieron "preguntas muy interesantes" y de quienes supo más tarde "que habian considerado la entrevista como una verdadera clase de pastoral moderna. ¡Me alegro!" (12 de junio de 1978), pasando por un jesuita de la India entusiasmado con "el milagro de la arquidiocesis" (26 de septiembre de 1979), por un grupo de catecumenos que querian trabajar en la arquidiócesis (1 de marzo de 1979), hasta el arzobispo de Maracaibo, el obispo de Avellaneda (Argentina), el cardenal Lorscheider, Mons. Barbarén y otros obispos latinoamericanos.

La entrevista con el obispo de Maracaibo fue curiosa por la oferta que trajo a Monseñor y porque asi le permitió formular una vez más cuál era su misión como pastor de la arquidiócesis. En su diario, Monseñor cuenta que el ar- 
zobispo venezolano venía a ofrecer su colaboracion, pero que en concreto traía, además, una propuesta del presidente demócrata cristiano venezolano. Monseñor le respondió lo siguiente, "...yo decidí desde el principio que actuaria como pastor, como siempre he tratado de hacerlo. Ya que en el aspecto político el señor presidente de Venezuela ha tenido oportunidades de tratar muy a fondo el problema político de nuestra pais con el ingeniero Duarte... Pero desde el punto de vista pastoral, solo pediría la influencia internacional para suavizar los extremistas de izquierda y de derecha y tal vez mandar ayudas políticas a los diferentes partidos de nuestro país, pero esto pertenecía al campo de la política. Mi afán como pastor es buscar la unidad, suavizar tanta violencia y que si en este sentido algo podrian hacer, sería pastoralmente, una verdadera colaboración con la Iglesia que mucho agradeceríamos" (18 de diciembre de 1979).

A estas visitas se añaden las de los representantes de las diversas instituciones de ayuda internacional como CEBEMO, ADVENIAT, MISEREOR, Catholic Relifef Service, CARITAS Internacional, Cor Unum, etc. A estas instituciones les explicó que "viviamos en emergencia, que habia muchas familias de desaparecidos, de asesinados, de capturados que era necesario ayudar..." (11 de septiembre de 1979).

Los protestantes de diversas denominaciones se acercaron a Monseñor y en el diario se recogen algunos de estos encuentros. Así, se entrevistó varias veces con miembros de la Iglesia Bautista Emanuel, otras tantas con representantes del Consejo Mundial de Iglesias, asistio a una convivencia de pastores bautistas ("unos $\mathbf{4 0}$ pastores deseaban verme y conversar conmigo sobre problemas cristianos, evangélicos...," 15 de abril de 1979), aprobó el trabajo asistencial propuesto conjuntamente por un pastor y un párroco, recibió a un pastor metodista, a una brasileña del consejo ecuménico norteamericano, a representantes del Consejo Mundial de Iglesias con sede en Suiza, a una comisión ecuménica de derechos humanos con sede en Canadá. El Consejo Mundial de Iglesias Cristianas con sede en New York lo invitó a dar unas conferencias, pero al final canceló el viaje por "mi compromiso de estar con mi pueblo," pues eran momentos muy dificiles por la violencia y la represión desatadas en el país (7 de noviembre de 1979). A todos les brindó una acogida cordial y colaboró con ellos para construir un ecumenismo desde el compromiso evangélico por los más pobres y desposeídos.

Una manifestación de su ecumenismo fue la semana de la unidad, celebrada anualmente en la arquidiocesis. La idea de directriz de estas celebraciones fue "hacer un trabajo más bien íntimo de conversión, que no expresiones exteriores que provocan problemas dada la sensibilidad política del ambiente y dado también que muchos protestantes están siguiendo una línea muy acomodaticia al gobierno (del general Romero)"' (8 de diciembre de 1978).

\section{Conclusión: el arzobispado un centro de mucha vitalidad}

Este recorrido de las visitas que Monseffor recibió y que registró en su diario nos lo muestran como un pastor accesible a todos los sectores sociales, 
dispuesto a oír primero y luego a orientar, a enseñar, ejerciendo así de un modo muy peculiar su función magisterial. Sin miedo a exagerar puede decirse que por Monseñor Romero y el arzobispado pasó todo el pais. Monsefior llegó a convertirse en el centro del país, en su pastor. En segundo lugar, podemos concluir que Monseñor era un hombre de diálogo, lo promovla y él mismo lo ponía en práctica continuamente, aprendiendo, interesándose, reflexionando y manteniendo su libertad para decir su palabra evangélica y eclesial con sinceridad y franqueza a todos, a cada uno lo suyo.

Hay que tener en cuenta que en el diario no está detallada toda esta actividad de Monseñor, ni mucho menos. En algunos lugares del texto se encuentran frases generales como la siguiente, que reflejan que su actividad en esta línea era mucho mayor, "varias visitas de carácter particular que me ocuparon todo el dia" (11 de abril de 1978), o "con alguien que sabe muy profundamente secretos y profundidades de la situación política del país" (19 octubre de 1978) o bien "esta mañana tuve una interesante consulta acerca de la situación política del pais. Muy aleccionadora..." (25 de octubre de 1979). Todo esto indica que Monseñor tenía acceso a fuentes de información de lo más variado y que no estaba, ni mucho menos, reducido al grupo de sus asesores y colaboradores más intimos.

Esta disponibilidad y accesibilidad se traducía luego en el carifno que el pueblo le manifestaba públicamente. Lo reconocían públicamente como su pastor. Por ejemplo, cuando se estaba preparando para uno de sus viajes a Roma recibio "muchas visitas de despedida y hay bastante cariño en la gente" (26 de abril de 1979). Esta intensa e indudable agotadora actividad de recibir gente continuamente lo cansaba, pero también le daba grandes satisfacciones personales y pastorales. Un día que concluyó a media noche dijo, "ha sido un dia que me ha llenado de muchas satisfacciones, asi como tambien he tenido momentos de desilusión al pensar en la división de nuestro episcopado" (19 de abril de 1979). El 11 de enero de 1980, en medio de la crisis política, comentó su día diciendo, "he tenido otras llamadas telefonicas a varias personas que han querido hablar conmigo y terminamos ya muy noche nuestra tarea, pero con la satisfacción de haber hecho algo por el Reino de Dios" (11 de enero de 1980).

Un ejemplo de un día cualquiera en el arzobispado podría ser el 19 de septiembre de 1979. Primero recibió a los dos fotógrafos de las revistas norteamericanas a quienes ya hicimos alusión antes y "luego siguió el trabajo de entrevistas, la mayor parte hoy, gente pobre o angustiada por situaciones de injusticia, madres de desaparecidos, a quienes traté de decir una palabra de aliento o dar alguna orientación para sus dificultades"' (19 de septiembre de 1979).

En los momentos más críticos se presentaba una avalancha de visitas sin anunciarse previamente, haciendo del arzobispado un centro de mucho trajín y de los días algo muy denso. Dos días después del golpe del 15 de octubre hubo muchas visitas de sacerdotes y seglares en el arzobispado con cuyas conversaciones "he aprovechado para enriquecer mis criterios y dar mis orientaciones como Iglesia, para iluminar este momento tan histórico" (17 de octubre de 1979). Monseñor recibia a todos "dada la intensidad de los problemas, ocupaciones, interés y otros casos similares hay que atenderlos sin dilación" (15 de 
febrero de 1980). En efecto, parece que desde enero de 1980 la actividad del arzobispo y del arzobispado experimentó un incremento notable a medida que se profundizaba la crisis política de la primera junta y del proyecto reformista. He aquí sus palabras sobre este momento, "... tenía... por la noche unas entrevistas de mucha trascendencia... vienen muchas consultas o visitas a las que, gracias a Dios, se les atiende con las luces que el Espíritu Santo me está dando y que le agradezco tanto, pidiéndole que la Iglesia sea siempre digna de estar presente en los momentos de nuestra historia" (7 de enero de 1980).

No sin cierto orgullo, en febrero de 1980, Monseñor vio convertido al arzobispado en un centro muy importante en la vida nacional por su capacidad de servicio, cada vez era "más denso de gente que visita, que consulta, que se reúne..." (20 de febrero de 1980). La Iglesia estaba eficazmente presente en medio de la crisis del pais al servicio del pueblo salvadoreño. La descripción de estos dias finales de su actitud arzobispal los describió de la siguiente forma, 'hubo en el arzobispado mucha actividad de visitas de sacerdotes y seglares; mientras en la sala de reuniones había un diálogo entre patronos y obreros de una fábrica que tienen connictos y huelgas. El arzobispado está siendo sede de muchas negociaciones, lo cual hacía por su fama de imparcialidad y de justicia" (12 de enero de 1980). Esta inmensa tarea era posible por la ayuda incondicional de sus vicarios generales, los curiales y sus asesores, quienes le ayudaban a atender "a la mucha gente que viene cuando hay estas circunstancias críticas en la política del país" (13 de febrero de 1980). Monseñor daba gracias a Dios por esta vitalidad.

\section{El pastor y la arquidiócesis de San Salvador}

Monseftor soñó con una pastoral para la arquidiócesis en la línea del Vaticano II, Medellín y Puebla, con una pastoral enraizada en la evangelización y en la opción por los pobres, y con una pastoral relevante para los gravísimos problemas del país. Más en concreto, siguió y potenció los lineamientos de lá semana de pastoral de la arquidiócesis de 1976, los cuales insistían en la formación de las comunidades eclesiales de base y en la formación de los agentes de pastoral, por una parte, y en la defensa de los derechos de los salvadoreños a la vida, por otra. Durante sus tres años de arzobispado consiguió inmesos frutos pastorales a través de sus visitas a las comunidades, a través de las celebraciones y de sus homilias dominicales en la catedral y a través de sus cuatro cartas pastorales.

Pero comprendió también que como pastor le competía impulsar una pastoral unificada y animar a todos los agentes de pastoral para formar un sólo cuerpo eclesial. En ello puso un gran empeño. Durante los meses de octubre y noviembre de 1978 se dedicó especialmente a esta tarea y a participar en las reuniones de pastoral en toda la arquidiócesis con el propósito de tener un mejor conocimiento y de proponer soluciones más adecuadas. En el diario se observa un gran interés por relacionarse con todos los agentes de pastoral, por asesorarse para guiar la vida cotidiana de la arquidiócesis y para iluminar las 
coyunturas importantes, por introducir los medios de comunicación social de la arquidiócesis en la pastoral de conjunto, por tratar con los seminaristas, sus futuros sacerdotes. Dada la situación nacional, la unidad de la pastoral no era cosa fácil, pues existian tendencias a ignorar dicha realidad o a introducirse en ella sin suficiente identidad eclesial. Monseffor fue muy consciente de este problema y por ello dijo el 1 de agosto de 1979 que deseaba para la pastoral "una línea actual de la Iglesia sin extremismos y que sepa comprender el momento que vive nuestra patria." Esta sintesis de necesario compromiso histórico y de identidad eclesial le preocupó especialmente después del golpe militar del 15 de octubre de 1979. Pero siempre la intentó y siempre la propuso y exigió de todos los agentes de pastoral de la arquidiócesis.

Qué pensaba y cómo reflexionaba Monseñor sobre la pastoral y sus problemas cotidianos es lo que presento en esta segunda parte sobre su diario. Al final, he añadido otros dos temas importantes en la actuación pastoral de Monseñor. El primero es su participación en Puebla y el segundo, su participación, como pastor, en las crisis políticas alrededor del 15 de octubre de 1979 y el 2 de enero de 1980. En la conclusión recojo cómo, a pesar de tan ingentes dificultades, Monseñor trabajó y gozó como pastor, y de qué manera, con gran humildad, reconoció y aceptó el amor del pueblo que pastoreaba.

\section{La actividad pastoral de Monseñor}

\section{a) Las visitas pastorales}

Monseñor visitaba constantemente las comunidades de la arquidócesis para animarlas y conocerlas personal y directamente. Durante sus visitas promovía el diálogo fácil con los miembros y los agentes de las comunidades. Su animación y su presencia eran especialmente importantes cuando había dificultades y desánimo. Por ejemplo, asistió a la reunión de la vicaráa de La Asunción en la capital para animar a sus miembros a resolver sus propios problemas, "un objetivo principal de mi visita a esta reunión era animar, porque he tenido noticias de que hay cierto decaimiento en el ánimo de algunos y les manifesté mi complacencia en el modo como se han organizado y el sentido de equipo que le han dado a todo su trabajo parroquial. Los felicité y les animé a ir adelante" (4 de junio de 1979). En estas ocasiones le daba gusto especial "ver la buena voluntad de resolver los problemas eclesialmente" ( 7 de junio de 1979).

Su respuesta a los problemas parroquiales y vicariales era el diálogo, nunca la imposición autoritaria vertical. Se trataba de construir comunidades eclesiales. Asi, después de una convivencia de comunidades eclesiales de base en Soyapango (el 7 de octubre de 1978) comentó que "fue muy interesante, sobre todo la participación de los jóvenes que, en diálogo conmigo, buscaban las respuestas de muchos interesantes interrogantes. Se discutió también la poca relación que existe entre el párroco y las comunidades. $Y$ les exhorté a buscar una solución que hiciera de esa parroquia una verdadera comunidad cristiana, cuya cabeza tiene que ser el párroco y con la cual tienen que entrar en un diálogo muy franco, para presentar el testimonio cristiano de una verdadera comunidad que sigue a Jesucristo." Asi, pues, promovió el diálogo con el pastor y 
dentro de la misma parroquia, respetando la autoridad local de cada párroco. Y eso aún cuando él personalmente no estaba siempre de acuerdo.

El 14 de julio de 1979 fue invitado a la parroquia de Comasagua para confirmar a un grupo, pero al llegar se encontró con sorpresa que no había gente ni en el templo ni en los alrededores, "le expresé mi sorpresa al Padre, tal vez con un poco de disguto y él me dijo que asi era de fría aquella gente. Yo insistí en que tal vez había fallado de parte del párroco mayor motivacion..." Cuando comenzaron a repicar las campanas se acercó un poco de gente, pero sólo un nif̂o para ser confirmado, "traté de revestirme de la mayor bondad y explicar la indiferencia frente a Dios y pedir a los presentes entusiasmar a su comunidad ante las bondades de nuestro Señor. Después de la misa invité a la gente a quedarse a dialogar para analizar esta situación y juntamente con el párroco y varias personas reconocen que sí hay frialdad y además hay miedo ante la situación del país... conversé fraternalmente con el Padre animándolo ya que es una labor ardua la que le toca en ese pueblo" (14 de julio de 1979).

En la vicaría de Mejicanos, después de ventilar los problemas del equipo de pastoral con sinceridad y claridad hacia el medio día "pude hacer una reflexión muy optimista, pensando en que nuestra reunión de esta mañana se parecía a las de los Hechos de los Apóstoles y que debiamos de buscar aquel ideal de hacer la comunidad cristiana, que es la mejor manera de resolver todos los problemas, cuando todos nos propongamos a ser verdaderamente la auto Iglesia de Jesucristo" (27 de junio de 1979). El 24 de noviembre de 1978 ante los problemas surgidos en la coordinación pastoral de la vicaría de Soyapango "yo tomé nota y supliqué ayudarme a visitarlas y trabajar también para que haya más entusiasmo en la labor pastoral de la vicaria."

Así como aprovechaba las entrevistas personales para enseñar, así procedía con todo el pueblo de Dios en sus celebraciones litúrgicas por los pueblos y las comunidades. Entre ellos se encontraba como en familia, muy a gusto, compartiendo la fe y la esperanza. El 18 de febrero de 1979, aprovechó la visita a la parroquia de Tamanique para autorizar a los ministros de la comunión para explicarles el sacramento de la eucaristía "y también los carismas que Dios da al pueblo de Dios. Llamé a las familias a cultivar las vocaciones sacerdotales y religiosas y a todos los laicos a buscar su propio carisma para servicio de la Iglesia. Después compartimos unos momentos muy felices en un ágape verdaderamente fraternal. Las comunidades expresaron pensamientos, poemas, canciones y se notaba que hay solidaridad del pueblo con su pastor. Me sentia en familia..."

En otra ocasion, el 22 de abril de 1979, cuando fue a la parroquia de San Sebastián, Ciudad Delgado, para reunirse con los agentes de pastoral se encontró con el templo completamente lleno de fieles "con los cuales tuvimos que hacer la reunión, invitándoles a comprender cuál es la verdadera misión y figura de la Iglesia y a partir de esa verdad, discutir la división que hay entre los fieles de dicha parroquia. Se expresaron en unas participaciones muy francas, los sectores tradicionales y los elementos de renovación.,"

Durante estas actividades apostólicas fuera del arzobispado Monseñor se encontró, por otro lado, con la realidad de la represión. Con dolor vio el 
rostro del terror en el cantón La Loma de San Pedro Perulapán, donde fue a decir una misa por dos campesinos asesinados recientemente, "se notaba en todos el temor, que se está sembrando en aquellos sectores de nuestro querido pueblo. Un temor que se justifica por la represion y el abuso de autoridad de los cuerpos de seguridad y sobre todo de los campesinos armados." Durante la celebración de la eucaristía hubo vigilancia y apuntaron la placa de su auto. En general, respiro la desconfianza "y se notaba una actitud agresiva o por lo menos una vigilancia desconfiada. Y comprendi el temor de los campesinos y por qué muchos hombres duermen fuera de sus casas, con el temor de ser sorprendidos por la noche..." (9 de octubre de 1978).

El 22 de abril de 1979, también en San Pedro Perulapán notó en el cuartel de la Guardia Nacional "ciertas vigilancias que me parececieron inconvenientes seguir fomentando con mi presencia en el pueblo" (22 de abril de 1979).

En la parroquia de Colón, en mayo de 1979, a donde fue a confirmar se encontró con otro tipo de terror, el causado por el régimen socio-económico. Al llegar notó que había un ambiente frio "y no logré entrar en un contacto más cordial con aquella gente que se ve muy reprimida. Parece que la situación de tener que trabajar en una hacienda es para ellos esta ocasión de vivir como dependientes del administrador. El cual también me pareció un poco despótico... Bajé con tristeza y también con el propósito de no aceptar otra vez una celebración dentro de una hacienda o finca y, mucho menos, aceptar las atenciones que la gente de las haciendas dé mientras se deja un tanto marginado al pueblo" (19 de mayo de 1979).

En marzo de 1980, visitando las parroquias de los franciscanos en el departamento de Chalatenango volvió a ver lo mismo, "en el pueblito donde fui y donde estuve también el domingo hay muchas quejas, pero como hay mucho terror tampoco pueden referirse con libertad a todo lo que está pasando"' (18 de marzo de 1980). Por eso, quizás, le chocó bastante el excesivo énfasis carismático que los franciscanos estaban promoviendo en sus parroquias.

En el diario, Monseñor destaca bastante los contactos que tenía con su pueblo pobre durante estas visitas pastorales, lo cual le causaba mucha alegría y le hacía sentir que con ese pueblo no costaba ser pastor. Veamos algunos de estos testimonios. El 2 de abril de 1978 fue a celebrar la fiesta patronal de la Colonia Miramonte (San Salvador), después de la eucaristía hubo una merienda, "una experiencia preciosa de sentido familiar de la parroquia" ( 2 de abril 1978). EL 23 de mayo de 1978 fue a bendecir la fachada y las torres de la iglesia del Carmen, en el departamento de Cuscatlán, donde estaba de párroco un sacerdote de edad avanzada, "gocé mucho por el ambiente tan acogedor de aquella comunidad. Les encarecí vivir siempre unidos a su párroco y a su obispo, es decir, sentir siempre con la Iglesia" (23 de mayo de 1978). El 11 de junio estaba en San Antonio, en Los Planes de Renderos, para presidir la fiesta patronal, "para el pastor una gran satisfacción compartir con aquella gente tan buena, una mañana tan preciosa." El 1 de octubre visitó Plan del Pino para confirmar, "la muchedumbre que salió a mi encuentro y que asistió a la Santa Misa era muy numerosa y se notaba mucha cordialidad y mucha acogida para las religiosas y para el obispo." Después de la liturgia le presentaron a los 
diversos grupos pastorales y sus actividades, "una preciosa combinación de la piedad y de la promoción..." (1 de octubre de 1978).

En su visita a El Paraíso, en Chalatenango, el 9 de julio de 1979, encontró "un enjambre de fieles, principalmente de jovenes, que acuden a vivir su vida cristiana junto a las hermanas (de La Asunción)," cuando antes de la llegada de las religiosas la vida religiosa estaba muerta. Al llegar lo recibieron con una atolada a la orilla del río, después les dijo la misa y los vecinos le hicieron discursos y sencillos actos artísticos, "más que todo (expresaban) la sinceridad y sencillez de aquella gente"' (9 de julio de 1979).

El 21 de julio de ese mismo año, después de visitar San Miguel de Mercedes, en el mismo departamento y donde también trabajaban pastoralmente las religiosas de la Asunción, expresó sus sentimientos de la siguiente forma, "me encantó ver cómo las religiosas de La Asunción que trabajan aquel pueblo... han hecho florecer el entusiasmo en la juventud. Y con ellos compartimos el almuerzo. Había alegría en el convento y al despedirme, sentí ese dejo de nostalgia que dan estas circunstancias, a pesar de la prueba que tuvimos que soportar todos (vigilancia de los cuerpos de seguridad y cateo antes de entrar al pueblo), pero que la superamos con la alegría cristiana" (21 de julio de 1979).

La fiesta patronal de Arcatao “fue... muy simpática, después pasamos al convento donde me hicieron un acto de cantos con mensajes muy bonitos y donde conversamos familiarmente con parte del pueblo y a la hora del almuerzo, con los catequistas de los diversos cantones, que entablaron un diálogo muy interesante con su pastor" (24 de agosto de 1979).

Monseñor también tenía detalles pastorales muy bonitos con su pueblo. El sábado 16 de febrero de 1980 había decidido dedicar el dia completamente a preparar su homilia del dia siguiente. La crisis politica ameritaba un cuidadoso estudio, pero a pesar de eso fue a catedral a bendecir una imagen de San Rafael para un cantón de la parroquia de Candelaria de Cuscatlán, "no quise negarme a esta petición de los humildes campesinos ya que en ellos siempre siento la presencia y el llamamiento de Dios."

Cuando no podia cumplir con estos compromisos pastorales porque su presencia era requerida en la capital o porque se encontraba indispuesto, aunque enviaba representantes, sentía que tales ausencias "no me dejan satisfecho, quisiera cumplir lo que he prometido, pero la salud a veces no responde y a esto se junta, tal vez, un poco de negligencia de mi parte" (15 de marzo de 1979).

Monseñor mostraba una veta religiosa muy popular que le permitía fácilmente entrar en comunicación con la gente sencilla y sentirse en familia entre el pueblo. En el diario dejó constancia cómo el 14 de enero de 1979, "en forma espontánea fui a visitar al Santo Cristo de Esquipulas de la parroquia de San Bartolomé Perulapía. Sorprendi al Padre Luis Montesinos, quien se sintió muy halagado con mi visita y me presentó desde los micrófonos a la romería y tuve que dirigir algunas palabras, hablando de la religiosidad popular y de aprovechar estos centros y devociones populares para crecer en nuestra fe" (14 de enero de 1979). 


\section{b) La liturgia solemne: la liturgia del pueblo}

La misa semanal de los domingos, a las ocho de la mañana, sintetizaba de un modo peculiar y novedoso la vida eclesial y social de la arquidiocesis y del pais entero. Para Monseñor resultaba "un acontecimiento muy consolador para la vida pastoral de la diócesis" (18 de marzo de 1978). En el diario, cada domingo aparece un breve resumen de la liturgia y de su homilia; había domingos especiales que le impresionaron más y, por lo tanto, dio más explicaciones. Por ejemplo, el 1 de abril de 1979 se sintió muy contento porque los somascos concelebraron con él la eucaristía y todos aquellos que se beneficiaban de sus obras apu tólicas llenaron la catedral. Para Monseñor esto fue muy importante por ser "un gesto de comunión muy digno de imitarse." Los dominicos y las dominicas hicieroı، otro tanto después de la beatificación del padre Francisco Coll.

El domingo 9 de marzo de 1980, Monseñor lo calificó de extraordinario por lo cual "le doy gracias a Dios por las inmensas satisfacciones que me ha dado hoy." La basílica estaba completamente llena de gente, delante del altar estaban los cadáveres de un matrimonio asesinado "porque tenian especial interés en que yo celebrara... en este gesto de amabilidad vi yo que era necesaria esta petición, aun advirtiendo el ambiente festivo que se hace en nuestras misas, pero que visto con espiritu de esperanza y oración, no desdecía ese ambiente a la tristeza de este hogar" (8 de marzo de 1980) y un representante de las iglesias libres de Suecia, quien estaba presente para hacerle entrega pública del premio de la paz de ese año. Antes de la eucaristía, cuando Monseñor advirtió a la madre del esposo asesinado sobre el ambiente festivo de la misa dominical, ella le respondió que "siempre había admirado esta misa y que eslaba su hijo muy de acuerdo en todo..." (9 de marzo de 1980). Así, la vida de la arquidiócesis, con sus alegrías y sus tristezas, sus luchas y sus esperanzas era celebrada litúrgicamente en la catedral.

Para Monseñor una liturgia solemne contaba con los siguientes elementos, un templo que rebasara de gente, desde las puertas y el atrio hasta el presbiterio, aunque no quedara espacio para el celebrante, un canto vibrante con "entusiasmo único" y sentir la fe y la alegria del pueblo. Le encantaba sobremanera encontrarse con la catedral abarrotada de gente porque era una expresión de la fe del pueblo y una excelente oportunidad para enseñar. Solemnidad significaba para él mucha participación. Al terminar la misa única de nueve dias del padre Rafael Palacios comentó que "fue muy solemne, muy participada. Se sentian las comunidades bien cultivadas que unidas en una catedral daban una impresión magnifica de estar participando muy activamente en la Eucaristia" (30 de junio de 1979).

La fiesta patronal de la capital lo era en verdad cuando concelebraba con todos los sacerdotes de la diócesis, cuando habia una gran representación de las comunidades, cuando el canto popular resonaba en la elevada catedral. Entonces la fiesta era patronal y del pueblo, "se sintió la presencia del Señor en nuestra liturgia y se notaba la alegría que era a base de fe y de esperanza cristiana" ( 6 de agosto de 1979). El domingo 5 de agosto de ese mismo año, gozó mucho con un coro de Tepecoyo que llegó a cantar en la festividad del patrón 
de la República, "unas sesenta voces, verdaderamente una algarabía de fiesta en la catedral. Y a la hora de la ofrenda también olrecieron frutos del campo de aquella comunidad junto con el pan y el vino. La gente aplaudió este gesto de simpatia y solidaridad" (5 de agosto de 1979). No era raro encontrarse con estos coros populares procedentes de las parroquias y de las comunidades en la catedral en la misa de ocho de los domingos. Era una forma de realizar la unidad eclesial en la eucaristia dominical. Después de la liturgia, Monseñor se acercaba a platicar con sus integrantes.

En la vigilia pascual de 1979 notó "la alegría... cordial sobre todo, a la hora de la salida cuando llegué a la puerla y despedi a la gente hasta que una lluvia nos impidió el paso a la salida y tuve que regresar en medio del gentío, que todavia esperaba salida, recibiendo carinosos saludos y deseando a todos felices pascuas" (14 de abril de 1979).

Comentando la fiesta del Sagrado Corazón de Jesús, el 2 de junio de 1978, dijo que la basílica, "el inmenso templo daba un espectáculo bellísimo ya que estaba completamente lleno de fieles y todos en actitud de oración." El 2 de septiembre, comentando una confirmación en una parroquia rural, exclamó admirado que habia "un ambiente de cordialidad y de alegria que nos hace pensar en lo bello que es una liturgia cuando de veras ha sido comprendida por la vida" (2 de septiembre de 1979).

Cada vez fue más frecuente que, después de las misas dominicales, se acercara a Monseñor la gente a saludario y también a cruzar cuatro palabras rápidas con el pastor, eran "visitas de gente del pueblo que siempre se apresura aunque sea brevemente con su obispo"' (25 de febrero de 1979).

\section{c) La homilia dominical}

Dentro de la liturgia dominical, la homilia ocupaba un sitio muy importante en la vida del arzobispo, de la arquidiócesis y de la nación entera. A nivel pastoral fue una novedad esperada semanalmente como buena noticia. A nivel personal era una tremenda responsabilidad que Monseñor tomó muy seriamente. El sábado, sobre todo cuando la realidad nacional se volvía dificil, Monseñor se reunía durante todo el día con sus asesores, un grupo más bien amplio, para prepararla, oír opiniones, reflexionar y discutir. Para él resultaba "muy interesante este estudio que semanalmente hacemos, porque nos da el pulso de la realidad de nuestro pais. Principalmente, analizamos esta vez la continuación de los actos violentos..." (26 de mayo de 1979).

Concluída la reunión, Monseñor se quedaba solo, arreglando sus apuntes, reflexionando y orando. Veamos lo que registra el diario sobre este punto que es de suma importancia porque muestra la responsabilidad personal que Monseñor sentia ante sus homilias y muestra cuán infundadas son algunas opiniones de que era manipulado por sus asesores al prepararlas. El 3 de marzo de 1979 comentó , "dediqué la tarde y la noche a preparar." El 15 de septiembre, dijo "quiera el Señor inspirar siempre mi palabra para ser justo en las apreciaciones;" el dia anterior había habido violencia en San Salvador resultando varios muertos y heridos. El 9 de febrero de 1980 observo, "pasé hasta muy 
noche arreglando estos apuntes y me levanté muy temprano también para preparar la mejor manera de exponer esta situacion del pais y el papel de la Iglesia, inspirado en las lecturas..."

De estas afirmaciones se puede concluir que, contrariamente a lo que algunos han afirmado, la homilía dominical era de su exclusiva responsabilidad. Es cierto que primero se informaba con sus asesores, a veces de opiniones contrarias, sobre determinados acontecimientos de la semana, y luego él, delante de Dios, se formaba su opinión y asumía la responsabilidad. En el diario hay constancia de dos situaciones particulares dificiles. La primera situación difícil fue la planteada por la invitación pública presidencial a participar en un diálogo nacional, a la cual debia responder también públicamente en la homilía del domingo. La reunión con sus asesores fue en la noche. Hubo desacuerdo sobre qué responder a la invitación del general Romero, "pues habia que mostrar la buena voluniad de la Iglesia, a pesar del escepticismo de unas promesas que deben esperar al aval de los hechos y no creerse, como el pueblo generalmente lo cree, unas simples promesas del presidente en un ambiente en que ha prevalecido la mentira, la distorsión, el engaño. Recogí las opiniones de uno y otro sector de la reunión y con la ayuda del Espiritu Santo, prepararé el informe que bajo mi responsabilidad se dará en la homilia del domingo" (19 de mayo de 1979).

El segundo domingo dificil, según lo que consta en el diario, fue el del 4 de noviembre de 1979, cuando quiso mantener un complicado equilibrio entre la represión de los cuerpos de seguridad, la buena voluntad de la primera junta de gobierno sin poder real y el rechazo absoluto de las organizaciones populares, “...pero con la ayuda de Dios, la inspiración del Espíritu Santo y con mi deseo sincero de ser justo y de ayudar sinceramente al pueblo, creo que me he formado los criterios suficientes para poder animar y denunciar en mi homilia de mañana..." (3 de noviembre de 1979).

El 7 de marzo de 1980, al discernir sobre los tres proyectos políticos en juego, el de la oligarquia, el de la democracia cristiana y Estados Unidos y el de las organizaciones populares, comentó lo siguiente "creo que para la Iglesia es un momento muy difícil de discernimiento, pero cuento con la luz del Espiritu Santo, que espero no me ha de fallar para orientar a mi comunidad..." (7 de marzo de 1980).

En los últimos meses de su vida, la homilía se fue prolongando cada vez más hasta llegar a dos horas. La homilia se prolongó en la misma medida que la situación política del país se complicaba. Monseñor era consciente de esto, le daba "la impresión de que estoy abusando del tiempo, pero siento, por olra parte, la necesidad de orientar esta gente que me escucha con avidez, ya que, precisamente, me prolongo porque no noto cansancio en el auditorio, que lo noto siempre atento y así me expresan que siguen con atención también a través de la radio"' (10 de febrero de 1980). El domingo, 15 de marzo de 1980, un día "de mucho trabajo pastoral y de grandes satisfacciones," la misa se prolongó hasta las diez y cuarto, "comprendo que fui excesivo en la predicación, pero los temas, los enfoque de una realidad tan densa y la atención de la gente me animan a no dejar de aprovechar esta atención que la gente me dispensa pa- 
ra dar a conocer cada vez más la catequesis de cuaresma, el pensamiento del misterio de Cristo que preparamos para la semana santa y también los criterios cristianos para enfocar las realidades tan complejas de nuestra patria" (15 de marzo de 1980).

Cuando supo que su homilia estaba siendo transmitida en onda corta a toda América Latina en colaboración con otras radioemisoras del continente, pues la YSAX había quedado fuera de servicio después de una bomba, se impresionó mucho, "por primera vez la voz de una homilia del arzobispado de San Salvador trasciende las fronteras y es escuchada por todo un continente." Pero no por ello se atemorizó más de la cuenta, al contrario, decidió, como era tan propio de él, aprovechar la oportunidad "para tener presente al auditorio, no sólo de mi diócesis, sino de América Latina, para la cual trabaja esta Iglesia de acuerdo con unas normas bien claras que se le dieron en Medellín y en Puebla' (2 de marzo de 1980).

Los aplausos tan frecuentes en medio de la homilia, explicó al auditorio de la catedral y de la radio "no me envanecian, sino que al contrario, me hacian sentirme más servidor de mi pueblo y tratar de interpretar esta comunión de sentimientos que expresan con sus aplausos" (23 de septiembre de 1979).

Platicando sobre lo interesante de este fenómeno de la comunidad social con dos sudamericanos especialistas en medios de comunicación, les dijo, "uno a veces... no se da cuenta de estos aspectos técnicos que ustedes conocen, pero sabe que la gracia del Espíritu Santo lleva a su Iglesia y hace fecunda su palabra. A eso atribuyo yo todo el éxito que ustedes creen haber encontrado en esa homilia, lo mismo que en todo mi trabajo pastoral. Confio en el Espiritu Santo y trato de ser instrumento de él, amar al pueblo y servirle sinceramente desde el evangelio" (27 de noviembre de 1979).

Después de terminada la misa dominical se fue haciendo costumbre, a finales de 1979, tener una rueda de prensa con los periodistas extranjeros, quienes junto con las entrevistas breves y rápidas del pueblo "le dan un ambiente muy pastoral, muy de familia, a esos momentos después de la misa" (4 de noviembre de 1979). Para Monseñor estos momentos eran algo "muy cordial en que me senti muy amigo de los periodistas y también había mucho pueblo que rodeaba esta reunión saboreando con gusto el diálogo, en el cual ellos, lambién gente del pueblo, intervenia con interesantes observaciones"' (10 de febrero de 1980). De este modo, el pueblo se fue incorporando a la rueda de prensa, haciendo preguntas y comentarios. El 9 de marzo de 1980, Monseñor hizo una súplica muy especial a la prensa extranjera para que no se dejara sorprender por la democracia cristiana en el poder, en la segunda junta de gobierno, pues la represión habia arreciado implacable e impunemente. Estas fueron sus palabras, según el diario, "suplicamos que llevarán hacia el extranjero la verdadera imagen de nuestra situación que es muy dificil de comprender, pues mientras se ofrecen reformas que benefician al pueblo, se lleva tambièn una represión que ofende terriblemente la dignidad de nuestro pueblo" ( 9 de marzo de 1980).

Esta liturgia dominical, en especial la homilia era escuchada por el pais 
entero. Pero asi como era elogiada por las mayorias, era criticada por otros, "no han faltado voces discordantes de la línea política que quisieran que uno llevara," comentó en el diario el 28 de octubre de 1979.

\section{d) Las cartas pastorales}

Monseñor escribió cuatro cartas pastorales y dio gran importancia pastoral a la elaboración de este magisterio doctrinal en las diversas situaciones, durante su arzobispado. En el diario ha quedado su testimonio de porque y como escribió la tercera y la cuarta cartas pastorales. La tercera carta pastoral, Iglesia y organizaciones políticas populares fue publicada el 6 de agosto de 1978 y la cuarta carta, Misión de la Iglesia en medio de la crisis del pals, un anto después. En ambos casos hizo amplias consultas y la redacción fue precedida por largas discusiones con sus asesores y colaboradores del senado, la comisión de pastoral, la comisión de Justicia y Paz y las vicarias. Para escribir la cuarta carta mandó consultar expresamente a las comunidades y a los párrocos antes de hacer el esquema definitivo.

Según el testimonio del diario, al escribir la tercera carta pastoral se sintio urgido a hacer "aclaraciones apropiadas a nuestro ambiente, donde hay tanta sensibilidad política y tanto peligro de confundir la verdadera fe con las actividades politicas" (13 de abril de 1978). Más tarde añadió que le preocupaba "tanta confusión que hay acerca de las organizaciones populares y del compromiso de los cristianos que pertenecen a estas agrupaciones o la inquietud de conciencia de otros cristianos que creen como una obligación organizarse políticamente. Los conceptos que se preparan son muy ricos y espero que ha de ser una pastoral de mucha utilidad" (19 de abril de 1978).

Monseñor quería hacer un documento claro y muy pastoral. Al menos eso pidió al Señor, "...un documento, le pido a Dios, muy claro en que la dignidad de la Iglesia y la claridad de la doctrina para los destinatarios reluzca para gloria de nuestro Señor" (26 de abril de 1978).

Una vez publicada, Monseñor la fue comentando en todas sus visitas y en todas sus reuniones y conversaciones, con grupos grandes o pequeños o con personas individuales. Un recuerdo especial quedó en el diario de la visita que le hizo una comisión de la parroquia Santa Lucía para entregarle "un bonito cuaderno donde estaban las conclusiones de sus reflexiones sobre mi carta pastoral. Les felicité y ví que francamente habian trabajado y sentido que la pastoral habia ayudado a iluminar su mente acerca de las organizaciones políticas populares y sus relaciones con la pastoral" (14 de diciembre de 1978).

La cuarta carta pastoral la quería dedicar, a los problemas actuales de la arquidiocesis, es decir, la relación con el gobierno de seguridad nacional y la presentación de una lglesia "que quiere ser auténtica y que no quiere compromisos con ninguna organización política, a la cual trata de comprender y apoyar en lo justo, pero sin identificarse con ellas. Y pedir a todos los cristianos que construyamos en nuestras comunidades eclesiales de base la verdadera Iglesia sin contornos ambiguos, sino que se defina verdaderamente la Iglesia que Cristo quiso construir..." (6 de abril de 1979). 
Esta carta la pensó como una respuesta al diálogo of recido por el gobierno del general Romero. Monseñor quiso escribir una carta "auténticamente eclesial, pastoral, para senalar las problemáticas y las posibles salidas, como pastoralmente podemos nosotros expresarnos." La carta sería eclesial porque esperaba abundantes opiniones de los párrocos y sus comunidades ( 25 de junio de 1979).

Las comunidades respondieron efectivamente. El 13 de julio, teniendo delante el material de las encuestas hechas, comentó que "entre todo resulta un material riquísimo para expresar la opinión de la Iglesia en esta hora en que se pide un diálogo nacional. Podremos hablar como Iglesia y desde la base misma de la Iglesia, como una expresión oficial de una carta pastoral. Pido a Dios que lo que ahora ha de seguir... sea bendecido por el Espíritu Santo que ilumine en este momento los caminos de nuestros cristianos" (13 de julio de 1979).

\section{La problemática de una pastoral de conjunto}

Simplificando un poco las tendencias pastorales existentes en la arquidiócesis se podría afirmar que había fundamentalmente dos extremos con diversos puntos intermedios. Por un lado, estaba aquella pastoral que subrayaba más las tendencias espirituales, individualistas y poco comprometidos con la trágica crisis del pueblo salvadoreño. Por el otro, estaban aquellas tendencias comprometidas directamente con los diversos movimientos populares e incluso con las organizaciones populares y las político-militares. En medio de estos dos extremos se desplegaba toda una serie de matices. Monseñor intentó unificar estas tendencias pastorales con lictivas dentro de los cauces marcados por el Vaticano II, Medellin y Puebla. Por eso se acercó constantemente a dialogar con los representantes y núcleos más significativos de ambas tendencias pastorales. Con los grupos más recalcitrantes de la primera tendencia fracasó, mientras que a los demás los logró mantener bastante unidos dentro de la pastoral de conjunto, por lo menos evitando contradicciones escandalosas. Por lo que toca a la segunda tendencia, siempre pudo mantener un diálogo franco y abierto, a pesar de la diferencia de perspectivas y criterios.

A traves del contacto personal directo y de los otros medios pastorales, como la homilia dominical, las cartas pastorales, la radio, el periódico, etc., Monsefor fue aglutinando, inspirando y promoviendo, poco a poco, sin imponer, presionando con suavidad, pero firmemente, venciendo obstáculos y resistencias, teniendo paciencia con todos, el llamado proyecto arquidiocesano de pastoral. Dentro de este proyecto fueron entrando incluso aquellos grupos o movimientos aparentemente más ajenos a ella. Monseñor trató de conquistarlos a todos dialogando y logró bastante en sus tres años de arzobispado.

\section{a) Construyendo la unidad arquidiocesana}

Cumpliendo con su deber episcopal, Monseñor aceptó la invitación del franciscano párroco de La Reina (Chalatenango), quien lo invitó por primera vez a visitar su parroquia hasta el 11 de marzo de 1980; y es que Monseñor no visitaba las parroquias ni las comunidades si no era invitado por los párrocos y 
los agentes de pastoral a quienes dejaba la iniciativa. Sabiendo bien la existencia de las dos tendencias pastorales conflictivas en la arquidiocesis y estando muy claro sobre lo que quería respecto a una única pastoral arquidiocesana, era igualmente muy respetuoso. Cuando Monseñor llegó a la parroquia se encontró con "una acogida cariñosa, esta gente es muy fervorosa, pero se nota una formación espiritual de tipo carismático, donde se vive una piedad intensa, pero no se nota un mayor compromiso con el momento actual. Sin embargo, tengo esperanza de que la nueva comisión de pastoral arquidiocesana ha de impulsar el proyecto pastoral a todas las parroquias" (18 de marzo de 1980). De momento no hizo nada más, aunque no le gustaba personalmente tanto entusiasmo carismático. Esta era su manera de proceder y de implementar su proyecto pastoral.

Monseñor comprendia situaciones pastorales como las de La Reina, pero como lo expresó a propósito de otra visita a una parroquia de la misma zona, había que confiar en el Espíritu Santo que estaba soplando en el pueblo de Dios. El 15 de marzo de 1980 estuvo en el cantón Los Martínez, en Tejutla, donde el párroco también franciscano y carismático, "es muy celoso, muy trabajador, pero quiere imponer una línea que el pueblo ya no acepta con toda confianza y que quisiera la linea de la arquidiócesis, que habla de las comunidades eclesiales de base. El padre se nota que tiene miedo a estas comunidades y yo traté de abrir esa confianza y de cimentar las quejas de pueblo, pero siempre uniendo al sentido jerárquico de Iglesia... Comprendo que el padre por ser extranjero y por no comprender la situación de nuestrá pastoral tenga estos reparos. Hay que comprenderlo, pero también hay que impulsarlo a no apagar el espíritu que se siente tan vigoroso en el pueblo" (15 de marzo de 1980).

Con relativa frecuencia asistió a las ultreyas de los cursillistas de cristiandad. En una de ellas, al regresar de Puebla, les comentó que algunos obispos latinoamericanos se habian quejado del movimiento por ser "muy aferrado a su método y poco se acomodan a la pastoral local. Y les dije que, por mi parte, pude dar testimonio de que aunque algunos también se han aferrado al método y se han alejado, cuento con un grupo decidido de cristianos que ha madurado y se han identificado con la pastoral de la arquidiócesis. Yo les felicité y les animé a seguir esta línea que es la auténtica de la Iglesia" (19 de febrero de 1979).

Mantuvo frecuentes contactos con los dirigentes del movimiento, con quienes cenaba, y a quienes proponia cuestiones pastorales que le preocupaban. El 6 de septiembre de 1979, durante una cena, intiodujo en la conversación un lema que la preocupaba mucho, el de la unidad del episcopado, "pidiéndoles que me señalaran fraternalmente que caminos podia yo seguir para encontrar la unidad con mis queridos hermanos obispos, porque si yo soy causante de algún estorbo para esta unidad, estoy dispuesto a enmendarlo..." Los cursillistas respondieron que la unidad se hacia conforme al evangelio, que era un fruto del Espíritu Santo y que el pueblo muchas veces interpreta mejor estas mociones que la misma jerarquía eclesiástica, "...no hay que buscar la unidad fuera de este espiritu, sino pedir para todos la conversión y que yo mismo también tratara de ser fiel al Espiritu y al evangelio, convirtiéndome cada vez. más a sus inspiraciones" (6 de septiembre de 1979). Otras veces la consulta 
la hizo en público, a todos los cursillistas reunidos en la ultreya. Monseñor siempre que asistía llevaba un mensaje, de modo muy particular le interesó que le ayudaran a planificar una pastoral urbana en los sectores de clases media y alta, algo bastante dificil. Por todo esto, Monseñor dijo, "le doy gracias a Dios de que cursillos podrán ser de verdad un instrumento de pastoral en la arquidiócesis" (18 de junio de 1979).

A los catecúmenos, a quienes visitó en una colonia donde se estaba cultivando ese movimiento, les habló de la necesidad de conocer y profundizar en la Biblia, tal como lo estaban diciendo, "pero que al mismo tiempo, trataran de adaptarse a la pastoral de la Iglesia local. Para mostrar así la autenticidad de sus intenciones católicas" (16 de marzo de 1979).

En su visita a un grupo de carismáticos en Santa Tecla, quienes estaban participando en una convivencia, los exhortó "a sentir con la Iglesia y a no quedarse solamente en emociones, sino en profundiar en una auténtica renovación del Espíritu. Advertí el sentido de solidaridad con el obispo, un propósito de ser fiel a la Iglesia jerárquica y a no desobedecer en nada a sus pastores" dentro de los cuales incluía a los respectivos párrocos (8 de abril de 1979). Al regresar de visitar una de las comunidades carismáticas de Chalatenango comentó lo siguiente, "el Espiritu Santo hace maravillas en esta gente sencilla que por otra parte, son promovidos por la renovación en el Espíritu, que este padre franciscano fomenta con bastante equilibrio" (17 de enero de 1980). A Monseñor lo que le interesaba era que siempre, cualquiera que fuera la tendencia o el método utilizando en la pastoral, se mantuviera el equilibrio y se promoviera entre el pueblo la experiencia de Dios. Esto fue lo que anduvo predicando entre estos movimientos aparentemente menos comprometidos con la realidad nacional.

Dentro de sus visitas también incluyó al Opus Dei, el cual eran parte de su diócesis. Comió con ellos en varias ocasiones; sus miembros, por su parte, le informaron de sus actividades, sobre las cuales hizo el siguiente comentario, "es una obra silenciosa de mucha espiritualidad... Me parece que es una mina de riqueza para nuestra Iglesia, la santidad del laico en su propia profesión..." (6 de septiembre de 1979). Sin embargo, en público les advirtió sobre su tendencia a permanecer al margen de la pastoral arquidiocesana, por temor al compromiso histórico.

Si bien por este lado Monseñor buscó la forma de acercar a los sectores y a las tendencias más espiritualizantes al proyecto pastoral arquidiocesano, por otro lado, de la misma forma, trató de conservar el equilibrio y mantener la unidad con quienes tendían a un mayor compromiso que llevara a la politización y a perder la identidad eclesial. Al tratar con esta segunda tendencia Monseñor no condenó su enorme compromiso histórico, cosa que exigia, más aún, también exigía el compromiso polílico. El problema estaba en mantener la identidad sacerdotal y eclesial. Esta problemática se agravó alrededor del 15 de octubre de 1979, pero después se suavizó.

Sus visitas a las comunidades le permitieron palpar directamente cómo sentian y pensaban políticamente muchos cristianos, en concreto, la tensión entre justicia y práctica. Esto fue motivo de enorme preocupación para él. En 
una almuerzo donde intercambió ideas con los representantes de la parroquia de San Martín, una zona muy golpeada por la represión gubernamental, el 11 de noviembre de 1979, oyó "puntos de vista politicos que me preocuparon un tanto porque prevalece el criterio de sus análisis políticos, que el criterio pastoral que su obispo les ofrece. Igualmente sentí esta preocupación por la noche en la colonia Santa Lucía... Estos dos encuentros me han dejado muy preocupado y he de buscar, junto con los colaboradores directos de la diócesis, la manera de una mejor instrucción religiosa, a fin de que prevalezcan los criterios cristianos sobre los análisis políticos" (11 de noviembre de 1979). Nótese que estas conversaciones fueron a escasas semanas del 15 de octubre.

En San Antonio Abad, en una reunión con los principales dirigentes de la comunidad, con quienes estuvo para reflexionar sobre lo ocurrido en El Despertar, entraron a fondo y con toda sinceridad "en los errores que pudieron ser causa de grandes tragedias. Descubrimos que la mezcla imprudente de la política con la pastoral hace mucho mal y hemos acordado que todo agente de pastoral respete completamente su trabajo pastoral, sin mezclarlo en implicaciones de organizaciones políticas" (4 de marzo de 1979).

Si las comunidades cristianas estaban muy politizadas, tal como lo estaba la sociedad entera, no era extraño que el clero también lo estuviera. Había un sector al que llamaba "progresista" o "de izquierda" que se separó de su línea pastoral y manifestó sus diferencias públicamente en un documento anónimo publicado después del 15 de octubre de 1979. El documento era una respuesta a la postura de apertura y de esperanza que Monseñor tomó ante los militares jóvenes y la primera junta de gobierno. Antes del golpe, aunque indudablemente ya existian di ferencias pastorales y políticas marcadas por la proximidad o identificación de este sector con las diversas organizaciones populares, no hubo mayores dificultades. Asi, cuando en agosto de 1979 los representantes de este sector organizaron tres dias de oración y ayuno, Monseñor respetó la iniciativa, "recomendándoles la máxima prudencia para no comprometer a la arquidiócesis." Los organizadores lo mantuvieron informado y Monseñor comentó al respecto, "creo que se trata de una iniciativa sacerdotal y eclesial... (donde) prevalecerá el valor espiritual de la oración y el ayuno y redundará en una denuncia profética como ellos aseguran para detener esta ola de crímenes, de atropellos en que los mismos sacerdotes han sido víctimas" ( 18 de agosto de 1979). El último día, un domingo, Monseñor aceptó decir la misa de las ocho con ellos y les permitió hablar para explicar al auditorio el sentido de esos tres dias de ayuno y de oración.

El 22 de noviembre de 1979, llevó el documento anónimo a la comisión de pastoral arquidiocesana. El sabia que el documento había sido elaborado y distribuido por un grupo de sacerdotes, religiosos y laicos. El documento en sí contenia un análisis de la coyuntura política y sacaba conclusiones "a veces ofensivas y negativas contra nuestra Iglesia." Algunos de los participantes en la sesión intentaron justificarlo como un esfuerzo para iluminar la confusión existente a propósito de la postura adoptada por la lglesia oficial después del golpe. Pero otros defendieron la posición de Monseñor, quien por su parte les hizo ver "que parecía más bien un análisis politico que no un documento de 
pastoral y exhortaba a que tratáramos de hacer Iglesia y no política y que, en este sentido, pedia una máxima sinceridad y confianza en el arzobispo..." (22 de noviembre de 1979). La reunión de la comisión no fue fácil, aunque hubo sus momentos de "acaloramiento." Al final, según su última apreciación, prevaleció "la confianza con que se han expresado sinceramente las opiniones en este campo tan dificil de la fe y la política"' (22 de noviembre de 1979).

Al dia siguiente llevó el asunto al senado presbiterial, lo cual "me dio mucha satisfacción la solidaridad de la mayor parte de todos los senadores." En la discusión, sin embargo, pudo identificar "providencialmente a sacerdotes que están más con las líneas políticas de las organizaciones populares que con la pastoral de nuestra Iglesia." Ante este descubrimiento, Monseñor expresó su "sentimiento profundo de pastor al no contar con la sinceridad de algunos de los colaboradores más intimos y les exhorté a que, entre todos, y por el bien de la Iglesia, construyéramos el Reino de Dios. Y desde ese Reino de Dios que lo sintiéramos profundamente en la fe, podriamos iluminar las realidades políticas y el bien de esta sociedad de nuestra patria" (23 de noviembre de 1979).

El 11 de diciembre de 1979, Monseñor llevó el problema a la comisión de pastoral otra vez. Esto era una muestra de su profunda preocupación. La reunión "estuvo muy animada." El grupo de sacerdotes implicados en el documento expresaron en una carta su negativa a entrar a la sesión porque no había ambiente de diálogo, alegando "que la Iglesia volvía a sentirse maestra, que estaban descontentos con ciertas publicaciones, que la junta anterior había terminado mal, sobre todo por la pésima interpretación del arzobispo." Ante esta actitud, la postura de Monseñor, tal como la explicó en el diario, fue, en primer lugar, tratar "de estar serenos y dije que la comisión de pastoral era un instrumento de consulta del obispo, el cual señalaba los temas según la consulta que él quiere hacer y siendo que la consulta se había preparado y señalado en la agenda, que se realizara como estaba preparada. Y que los que no habian querido venir con eso estaban manifestando su poca capacidad de diálogo, y que se les invitaba a expresar con serenidad, en diálogo con el obispo o con las organizaciones que el episcopado tiene para el diálogo, su propio parecer y confrontarlos y corregir o afianzar los modos de pensar. A un diálogo no se va a defender posiciones ni a expresar resentimientos, sino a buscar la verdad y a compartir el amor y la unidad de nuestra Iglesia" (11 de diciembre de 1979).

El dia anterior, el 10 de diciembre, se había reunido con la comunidad de la colonia Zacamil, la cual se habia negado a continuar la distribución de Orientación, el periódico semanal oficial del arzobispado. Estaban descontentos con la línea del semanario, "se sienten aludidos cuando se habla de la división de la Iglesia y de los grupos que más bien son politicos que eclesiales. Traté de acogerles todas sus inquietudes, sus quejas. Les manifesté sinceramente el pensamiento de la pastoral de nuestra arquidiócesis y los invité a continuar un diálogo con los mismos responsables de la prensa y de la radio y creo que fue muy positivo el diálogo. Saliendo contentos de que se podía dialogar y de poder exponer sus pensamientos, pero al mismo tiempo oir otros pareceres" (10 de diciembre de 1979). 
Una semana más tarde, el 19 de diciembre, la situación planteada hizo crisis de una forma inesperada. Estando Monseñor en la parroquia de Quezaltepeque, le avisaron que las Ligas Populares se habian tomado el arzobispado. De inmediato se comunicó con el responsable de la ocupación para preguntarle cuáles eran sus objetivos y protestar por lo que consideraba una ocupación indebida. Presionando, logró que le dijera por teléfono que deseaban que les ayudara a encontrar los cadáveres de los muertos en los desalojos que acababan de hacer los cuerpos de seguridad, que les devolvieran los prisioneros hechos y que hiciera "una denuncia de la forma demagógica" cómo la primera junta de gobierno estaba operando.

Su sorpresa fue mayor, cuando se le presentó el párroco de la colonia Zacamil para informarle que los ocupantes deseaban dialogar. Monseñor comentó, "parece estar muy comprometido con esta ocupación." Su primera reacción, entonces, fue poco serena, "me alteré un poco al decirle que no representara tan directamente los intereses de una organización, siendo el pastor de todos los cristianos. Hubo algún pequeño altercado con él y otros sacerdotes, pero después terminé reconciliado con él, diciéndole que confiaba en su sentido sacerdotal y pastoral para comprender esta delicada situación que vivimos y no parcializarse." En el diálogo con los ocupantes, éstos reiteraron sus objetivos, "dialogamos bastante sobre diversos aspectos, incluso les oí bastante desconfianza con la actuación de la Iglesia, como si hubiera dado una vuelta de ciento ochenta grados, expresión de ellos, de su actitud ante Dios, como si hubiera traicionado los intereses del pueblo, lo cual me molestó bastante viendo la sinceridad con que trato de defender como siempre, desde el evangelio los intereses de nuestro pueblo. Y dije que, por hoy no interesaba tanto esta discusión general, sino que volviéramos al caso concreto de la ocupación. " Continuaron discutiendo sobre los rehenes; Monseñor, les ofreció quedarse para darles seguridad a cambio de liberar a aquéllos. Los ocupantes prefirieron que permaneciera fuera para negociar con la junta.

Al dia siguiente, 20 de diciembre, casa presidencial le manifestó su buena voluntad para resolver la ocupación. Monseñor Modesto López, párroco de la catedral, le avisó que el Bloque Popular Revolucionario (BPR) se habia tomado el templo y que tenian un muerto dentro.

El 21 de diciembre se reunió con sus asesores para reflexionar sobre los sucesos protagonizados por las organizaciones populares "que fanatizan un poco y en las cuales también se implican cristianos y hasta sacerdotes." Sin embargo, Monseñor expresamente dijo que no quería "juzgar con cerleza, pero sí me hace sospechar (que el párroco estaba implicado directamente), lo mismo que otros elementos de comunidades de esa misma parroquia." Más tarde, el ministro de salud le llevó los datos exigidos por los ocupantes del arzobispado.

La ocupación terminó el 22 al medio dia, "lamentamos que haya habido tantas molestias y que hayan participado elementos cristianos es incomprensible, pero en estos momentos de confusión hay que tratar de comprender" ( 22 de diciembre de 1979). Mientras el arzobispado estuvo ocupado no se movió de la capital, canceló todos sus compromisos, enviando representantes a sustituirlo. 
El 4 de enero de 1980, fiel a su compromiso pastoral con el diálogo se reunió con los cinco sacerdotes con quienes tenía "algunas dificultades." Su evaluación de esta conversación fue la siguiente, "dialogando muy a fondo y buscando sinceramente la solución de estas dificultades y desconfianzas, he encontrado mucho valor humano, cristiano y sacerdotal que seguiremos cultivando en ulteriores reuniones" (4 de enero de 1980).

El 14 de febrero de 1980, cuando la situación política habia cambiado completamente con la junta demócrata cristiana y cuando ya sus esperanzas en una posibilidad de cambio real habían muerto, Monseñor se volvió a reunir con estos sacerdotes "que son más señalados como avanzados del lado de izquierda. Con ellos tuve una conversación muy fructuosa y esta reunión de hoy ha sido también de gran acercamiento, en que muchas veces como que parece que estamos más separados y hay más peligros, cuando, de verdad, hay esfuerzos sinceramente pastorales y sacerdotales." Aprovechando el restablecimiento de la confianza y el buen ambiente, él fue más allá al "expresar mis temores y reclamar que seamos, en medio de los vaivenes de la política y de nuestras aficiones por las organizaciones politicas popúlares, seamos verdaderamente signos del Reino de Dios, porque para eso estamos en la Iglesia, para dar la presencia de la Irascendencia en medio de los trabajos de la tierra. Ellos han comentado, muy según el evangelio, este pensamiento. Seguiré pidiendo a Dios para que sean... no enemigos, no victimas, sino verdaderos colaboradores" (14 de febrero de 1980).

No obstante sus reservas y dificultades respecto a las organizaciones populares, Monseñor invitó a las tres principales (BPR, FAPU y Ligas Populares) a una reunión del clero para que expusieran sus puntos de vista. Pero el día de la reunión, el 6 de noviembre de 1979, sólo se presentó el FAPU, de cuyos representantes escucharon "una explicación muy interesante de su ideología y de las estrategias." Después las vicarias se reunieron para responder a las siguientes preguntas, cómo inciden en la pastoral arquidiocesana estas organizaciones y cuál debe ser la actitud de la Iglesia. La reflexión por grupos, según el diario, fue "muy enriquecedora." En el plenario las vicarias aportaron muchas ideas que Monseñor interpretó como un afianzamiento de su línea pastoral "de encarnación en la realidad nacional" sin perder la identidad eclesial.

Después, como conclusión, tomó la palabra y les enseñó aquello que le habia llamado la atención de las organizaciones populares, "la claridad con que los organizados exponen sus ideas, la naturaleza de su organización, sus estrategias..." Claramente les dijo que deseaban mucho que los sacerdotes, los agentes de pastoral "teniendo toda una ideología, toda una tradición de la naturaleza, misión y vida de la lglesia, tomemos cada dia más conciencia y sepamos expresarla no sólo para explicar lo que es la Iglesia, sino para vivirla con verdadera identidad de Iglesia, sin salirnos de nuestra línea eclesial, desde la cual podemos hacer tanto bien a las mismas realidades políticas, pero en la medida en que seamos auténticamente Iglesia de Jesucristo. También les expresó cómo estos hombres de las organizaciones se muestran tan entregados al trabajo liberador del pueblo y que eso lo comprendemos plenamente, pero nos afligen las esclavitudes y realidades terrenales... que todo eso lo podemos 
comprender y ser solidarios con esos esfuerzos liberadores, pero desde nuestra perspectiva que es mucho más completa porque arranca de la liberación del pecado y promueve al hombre hasta la dignidad de hijo de Dios... y por eso estamos más capacitados para comprender las liberaciones de la tierra y orientarlas a la gran liberación de Cristo. Y también les dije a los agentes de pastoral que la unidad que estas fuerzas demuestran es secreto de sus eficacias y que nosotros también ya que tenemos una teología sobre la comunión, que procurámos no dispensarnos, ni muchos menos criticar unos contra otros, ni muchos menos separarnos de los ideales y de los objetivos que el obispo, como principal responsable de la pastoral, señala... cuando haya diferencia que dialoguemos y nos entendamos y procuremos nunca romper nuestra comunión de Iglesia..." (6 de noviembre de 1979).

\section{b) Los organismos de consulta}

A Monseñor lo que lo ponía nervioso era la falta de diálogo y de apertura, la falta de confianza y de honradez. Las opiniones contrarias no le asustaban, al contrario consideraba interesante discutir sobre diferentes puntos de vista, era una forma de enriquecimiento, la cual servia, al menos a él, para hacerse una idea más adecuada de las cosas y las situaciones. En el diálogo decia, "no se trata de imponer, sino de dialogar para que todos convencidos caminemos por donde el Señor quiere que caminemos" (2 de de junio de 1979).

Quería que el clero fuera claro y expresara sus opiniones con libertad, pero con apertura para oir otras contrarias. Se trataba de aprovechar siempre lo bueno, descartando lo incorrecto o inadecuado. Esta era para él una forma de discernir la voluntad de Dios y, por lo tanto, un medio muy útil para construir el reino de Dios. Preparando una reunión del clero en mayo de 1979, pensaba pedir que "cada sacerdote exprese con toda confianza y libertad sus sentimientos, su pensamiento, sus criterios acerca de la actitud de los sacerdotes y de la Iglesia en general" ante la crisis. Después de la reunión dejó constancia de su satis facción personal por "la sinceridad y el interés que se mostró para actuar como verdadera Iglesia que evita confusiones y ambiguedades en un ambiente tan crítico como el que estamos viviendo" (25 de mayo de 1979).

El 4 de septiembre de 1979, en la reunión del clero surgieron diferencias sobre las comunidades eclesiales de base. Aunque la mayoria de los sacerdotes estaba con él y con las comunidades, otros expresaron sus desacuerdos "no por falta de comunión, sino por no estar de acuerdo en muchas cosas... Así lo dije al final, que todas estas tensiones mientras se mantuvieran en la comunión eran signo de salud, que procuráramos nada más hacer prevalecer los supremos valores de la caridad y de la unidad" (4 de septiembre de 1979).

Monseñor gozaba mucho cuando veia la madurez del clero reflexionando con realismo, a pesar de tener criterios politicos y pastorales diferentes. Así, por ejemplo, el 14 de enero de 1980, después de una reunión del senado, "los felicité y les supliqué seguirme asesorando para en este mar revuelto de la política de la patria, nuestra Iglesia sea conducida con criterios evangélicos y pastorales que la hagan útil precisamente en este torbellino que nos rodea" (14 
de enero de 1980). En estas ocasiones, Monseñor decía notar cómo estaba creciendo la Iglesia.

Por todo lo dicho anteriormente se ve que el senado era uno de sus órganos de consulta en el cual recogia el parecer y las tendencias diversas, y conflictivas del clero, pero al mismo tiempo era un medio para ir haciendo actual la unidad eclesial en torno a un sólo proyecto pastoral.

En la primera reunión del nuevo senado, poco antes de su muerte, el 20 de marzo de 1980, exhortó a los nuevos senadores "a procurar la unidad del clero, ya que estaba representado en el senado todo el clero con sus diversas corrientes y modos de pensar de nuestros sacerdotes. También les dije que teníamos que poner en nuestra reunión una base humana de confianza, de amistad, de sinceridad, ya que no basta el sentido de fe y sobrenatural con que debemos considerarnos en el ambiente de nuestra vocación sacerdotal, sino que, esa base humana de amistad es la que dará un sentido agradable, práctico y eficaz a nuestro trabajo en equipo, en función principalmente de todos nuestros sacerdotes a quienes representamos" (20 de marzo de 1980).

Con el senado también se reunía con frecuencia para evaluar la arquidiócesis, lo cual siempre resultaba muy interesante. Era una forma de "tomar el pulso a la marcha de la diócesis y orientar cada vez mejor nuestra pastoral" (27 de marzo de 1979).

Para coordinar la pastoral arquidiocesana Monseñor estableció y promovió con mucho interés al consejo arquidiocesano de pastoral, el cual contaba con una comisión ejecutiva más pequeña para ser más eficaz. Eran miembros de este consejo los 10 vicarios foráneos y los representantes de las religiosas en pastoral y de los laicos, lo cual representó una novedad eclesial. Aparte del senado y del grupo que se reunía para preparar la homilía de los domingos, este era un tercer foro en el cual Monseñor se asesoraba con bastante frecuencia, concretamente sobre los asuntos pastorales. Ciertamente, según lo dicho en el diario, tenia muchas esperanzas en este organismo en cuanto a la coordinación y animación de la pastoral (25 de abril de 1978).

Las diferentes referencias al consejo de pastoral dan una idea de su desarrollo y de sus funciones a lo largo de estos antos. En mayo de 1979, cuando apenas había comenzado a funcionar ya era para Monseñor "muy consolador hacer una evaluacion, reconocer las diferencias de que todavía adolecemos, pero con entusiasmo proponer sugerencias para llevar este trabajo del consejo a una verdadera fuerza pastoral de coordinación, de orientación de la pastoral de toda la arquidiócesis" (29 de mayo de 1979). Una arquidiócesis compleja y complicada como se ha podido venir observando a lo largo de este estudio.

En noviembre del mismo año encontraba "mucha creactividad, hay verdadera bendición del espíritu de Dios entre nosotros" (22 de noviembre de 1979). En febrero de 1980 dijo que esta era la comisión más importante "ya que me ayuda a coordinar las diversas actividades de las vicarias de la arquidiócesis y orienta con sugerencias nuevas nuestra pastoral" (21 de febrero de 1980). En marzo, la función del consejo estaba más definida ante la existencia de tendencias pastorales conflictivas en el clero y que Monseñor esperaba 
poder coordinar, respetando un sano pluralismo, "una coordinación que logre la armonia entre los dos sectores hacia los que tienden nuestros agentes de pastoral. Unos que no quieren comprometerse con la pastoral de la arquidiocesis y otros que se van quizás al extremo muy avanzado, causando así desconfianza a los otros. Hay serias reflexiones sobre este hecho" (17 de marzo de 1980).

En el diario hay constantes testimonios de desayunos que duraban hasta media mañana y reuniones con grupos especializados en problemas concretos, analistas de la situación del país, teólogos, responsables de la pastoral, etc.

Dentro de esta tarea de coordinar y orientar la pastoral, el personal del arzobispado era importante para Monseñor, aunque eran tantos sus compromisos fuera y dentro de las oficinas que lamentaba no poder atender más personalmente y mejor a sus más cercanos colaboradores. Cuando en ocasiones festivas comian todos juntos sentía un gran calor humano y una profunda necesidad de estar más cerca de sus colaboradores. En estas ocasiones se alegraba de poder, aunque fuera por breve tiempo, "entablar relaciones más humanas y cristianas" con ellos (26 de marzo de 1979). Entonces, Monseñor sentía con fuerza la necesidad de repetir tales reuniones "para identificarnos en nuestros criterios de servicio a la lglesia desde puestos tan importantes" (14 de diciembre de 1979).

Habia organizado dentro del arzobispado un consejo administrativo para ordenar la administración interna de la curia. Pero era difícil "ordenar" las actividades de Monseñor, aunque los miembros de este consejo se reunian con frecuencia para ello. En la reunión del 22 de agosto de 1979, Monseñor dijo haber aceptado "algunas deficiencias de mi parte y prometi corregirlas y animar a ellos a seguir trabajando, ya que su consejo es sumamente.útil para la administración de la curia." Para dar más eficacia a esta línea administrativa pidió la asesoría de la Fundación para el Desarrollo de la Vivienda Mínima, una institución de inspiración cristiana que tenia experiencia en la administración empresarial.

Por su parte, los vicarios generales cuando evaluaron su trabajo en la curia en febrero de 1980 encontraron que había falta de comunicación entre ellos y Monseñor, lo cual se traducía en repetición de órdenes y contraórdenes, ocasionando lamentables confusiones. Uno de sus vicarios le dijo "con franqueza fraternal que muchas veces mi actitud es como construir alguna disposición de los vicarios generales y que esto entorpece la marcha de la autoridad. Yo reconozco, pero vuelvo a insistir que necesitamos más comunicación..." (14 de febrero de 1980). A partir de entonces quedaron en reunirse cada semana. Un mes más tarde la situación persistía. En esta oportunidad, Monseñor reconoció que era una limitación en su manera de ser. En la reunión de los curiales "comentamos precisamente, que por deficiencias de mi carácter puedo causar a veces resentimientos o divisiones, pero que no dudaran de la fidelidad de estos colaboradores. Yo les dí la razón y les dije que había sido uno de los puntos de mi examen en el ejercicio espiritual de la semana pasada y que traia el propósito de que, con su ayuda, procurarámos trabajar más unidos, en más comunicación y que mutuamente nos corrigiéramos aquellas cosas que pueden 
entorpecer este trabajo comunitario tan interesante..." (3 de marzo de 1980).

Más serios fueron los problemas internos experimentados desde junio de 1979 entre el personal seglar del arzobispado. Habia malestar y corrían rumores de orden diverso. En buena medida los problemas se organizaban en los talleres de la imprenta Criterio. Monseñor trató de explicarles a todos "el procedimiento de la administración y pedirles también fidelidad jerárquica que necesita la curia diocesana para con su obispo, ya que formamos un equipo que es director de toda la arquidiócesis" (1 de agosto de 1979). En medio del conflicto, una de sus secretarias lo acusó de contradicción entre lo que decía y lo que hacía al tratar los problemas laborales internos. En la intimidad del diario, Monseñor comentó lo siguiente ante la acusación, "ante Dios he orado para pedirle sus luces y pedirle también mantenerme siempre fiel a lo que yo trato de seguir, el evangelio" (2 de agosto de 1979).

A pesar de estas limitaciones, su carisma de pastoral tan especial atrajo a otras personas quienes se le ofrecieron a trabajar en la curia sin salario. El 28 de noviembre de 1979, aceptó el ofrecimiento de secretaria que le hizo la esposa de un dirigente político joven de la democracia cristiana. A mediados de febrero de 1980 aceptó el ofrecimiento de una joven protestante a quien le dio trabajo como traductora del inglés. Hasta un poeta desconocido de Jucuapa, antiguo amigo suyo, le llevó unos poemas para que los publicara y destinara su producto al seminario (13 de noviembre de 1979).

\section{c) Los medios de comunicación social}

Monseñor Romero quería los medios de comunicación social del arzobispado como apoyo a la línea pastoral. Para él, la radio era de vital importancia, le urgía una buena radioemisora que difundiera el pensamiento de la Iglesia ( 8 de junio de 1979). El mismo grababa semanalmente un programa dialogado con una seminarista o con uno de sus asesores que se transmitia los miércoles y en el cual iba comentando los acontecimientos eclesiales y nacionales. Cuando estaba fuera, en Roma o en Puebla, llamaba por teléfono para no faltar a la cita con los radioescuchas. En estas oportunidades informaba de sus actividades e impresiones. En los momentos más críticos del país también acudía a la radio para dejar oir la voz del pastor.

La política que debía regir la radioemisora era la misma de todas sus actuaciones, comprometida, veraz y profética. A principio de 1980 , un programa diario de comentarios sobre la realidad nacional a cargo de los intelectuales de la Universidad José Simeón Cañas (UCA) causó dilicultades entre algunos de sus colaboradores en el arzobispado, quienes pidieron censurar antes de lanzar al aire esos comentarios o que sus autores se hicieran directamente responsables de sus contenidos. Monseñor intervino proponiendo dialogar entre las partes. En este diálogo su actitud personal fue "presionar un poco para que no nos dejemos llevar de la cobardia; verdadera prudencia, sí, censura, tambièn, racional, pero que no dejemos los programas de los comentarios, ya que son de mucha utilidad para orientar a nuestro auditorio en este momento tan confuso" (2 de enero de 1980). 
En Orientacion apoyo "que se suspendieran algunas notas muy piadosas y que se diera lugar a informaciones o a criterios que sean más útiles en el momento en que nuestro periódico es la única voz... se acordo... (asesorar a la responsable) de elementos que sean un poco agresivos, aunque se haya que frenar, pero siempre es bueno tener quienes impulsen también en este sentido" ( 9 de junio de 1979).

Consecuente con la importancia personal que daba a estos medios de co. municación, él mismo, personalmente, dictó por teléfono desde Puebla un artículo para el periódico. "Desde Puebla a mi arquidiócesis," en el cual envió sobre todo un mensaje de optimismo y de esperanza, a pesar de las dificultades internas de la conferencia y de la violencia que reinaba en San Salvador en esos dias. "Que Dios bendiga este esfuerzo de aprovechar los medios de comunicación social para que el mensaje del evangelio siga animando a nuestra querida comunidad arquidiocesana" (7 de febrero de 1979).

Dentro de este apartado podríamos considerar la correspondencia que recibía, la cual era bastante considerable. Por lo general, la revisaba en la noche, una vez que su secretaria particular la había puesto en orden y le habia hecho resúmenes. Era otro tipo de apostolado más personal y silencioso, "es mucha correspondencia que diariamente llega y gracias a Dios, creo que estamos haciendo también un verdadero apostolado a través de breves respuestas y mensajes oporlunos" (15 de noviembre de 1979).

\section{d) Relaciones fraternales con su clero y los religiosos}

En sus relaciones personales con su clero, Monseñor deseaba sobre todo "crear un sentido de fraternidad" cada vez mayor (15 de noviembre de 1979). Sin embargo, su constante actividad pastoral le impidió una relación tan personal como la soñada y anhelada con sus sacerdotes. Para Monseñor este tipo de relación era muy importante para construir la verdadera Iglesia. Cuando un sacerdote le hizo notar ésto, al regresar de una visita a una parroquia, prometió procurar "tener más cuidado y atención ya que constituyen la parte principal de nuestra pastoral y hay peligros de incomprensiones y también de divisiones. Yo le pido al Señor que nos libre de todos estos males y que nos de un clero unido, sano, eficiente para nuestra situación" (13 de diciembre de 1979).

Conversando de modo "amistoso e íntimo" con los párrocos de la vicaría de Mejicanos expresó el mismo deseo "de oir con toda franqueza sugerencias y aun quejas para mejorar mi relación con ellos" (30 de agosto de 1979). En la reunión del clero de marzo de 1980 insistió "en que esta institución del organismo de consulta que es el senado no quería agotar mis inlenciones de diálogo con cada uno de los sacerdotes, pidiéndoles excusas de no haberlos podido atender por tantos problemas que hay, pero prometiéndoles siempre mi sincera buena voluntad y pidiéndoles la colaboración para abrir canales acerca de estos diálogos personales" (4 de marzo de 1980).

En el diario hay variados testimonios de como Monseñor fomentó prácticamente este espiritu de cuerpo dentro de su clero. Con frecuencia visitaba a los sacerdotes enfermos, en sus parroquias o en el hospital. Si encontraba ne- 
cesidades económicas, los ayudaba discretamente en la medida de sus posibilidades. Si fallecian los iba a enterrar. Siempre que podia asistia personalmente a darles posesión de sus parroquias. Les entregaba las licencias ministeriales en un acto litúrgico en el cual congregaba a todo el clero. El sentido que tenía esta acción era el de otorgarles la misión a la diócesis y exigirles, al mismo tiempo, un compromiso pastoral público (8 de enero de 1980).

Preocupado por la identidad sacerdotal, organizó una semana para estudiar el problema en enero de 1979. A los que no se presentaron pensaba reclamarles y a todos los 70 participantes les exigió puntualidad y seriedad "ya que se trata de un problema que atañe tan profundamente a nuestro ministerio sacerdotal, para realizarlo como Dios quiere y la Iglesia lo necesita en esta hora" (8 de enero de 1979).

Monseñor hacía sus ejercicios espirituales anuales acompañado siempre de un grupo de sacerdotes. En marzo de 1979 los hizo con un grupo de unos 20 , "el grupo se compactó en una unidad encantadora y hubo mucha profundidad de reflexion, unos ejercicios espirituales verdaderamente sacerdotales, de gran provecho para nuestro ministerio, gracias a Dios" (5 de marzo de 1979). En marzo del año siguiente hizo tres días de ejercicios con algunos sacerdotes de la vicaria de Chalatenango. Inicialmente pensaban viajar a Guatemala para recogerse a las orillas del Lago de Atitlán, pero después prefírió quedarse por la inseguridad personal que corria. De lodos modos, fueron "dias de profunda reflexión y de convivencia muy fraterna e íntima con los sacerdotes..." (26 de febrero de 1980).

Visitaba a los demás sacerdotes cuando estaban haciendo sus ejercicios espirituales anuales, tal como lo dice en el diario el 11 de octubre de 1979, cuando visitó a la vicaría de Cuscatlán. El encuentro fue muy fraternal "muy cordial en que dijimos las verdades e hicimos propósitos de mejorar nuestras relaciones y nuestro deseo de una auténtica pastoral' (11 de octubre de 1979). Así, pues, aprovechaba estas ocasiones tan especiales para revisar junto con los sacerdotes la marcha de la pastoral de las vicarias e indudablemente ahi se incluian las relaciones con el obispo; eran momentos de sinceridad, de reconocer las limitaciones y de prometer continuar trabajando superando las limitaciones mutuas. Lo que más le gustaba de estas conversaciones era "cuando tratamos los aspectos humanos de nuestras relaciones como presbiterio de la arquidiócesis. Hay muy buena voluntad, nos dijimos mutuamente los defectos que pueden estorbar esta comunión no sólo de $\int_{e}$, sino psicológica y agradecí el señalamiento que se hizo de mis deficiencias, que pueden estorbar las relaciones que yo quisiera muy cordiales"' (14 de noviembre de 1979).

Las religiosas en pastoral tambièn entraban dentro de sus preocupaciones. A ellas también las visitó cuando estaban haciendo sus ejercicios espirituales; dialogó con ellas toda una tarde, "principalmente sobre los aspectos difíciles de la pastoral en un ambiente tan politizado, pero traté de decirles que, con toda franqueza, fuéramos valientes en llevar el mensaje evangélico y ser verdadera lglesia, la cual no vive de coyunturas ni teme las variedades porque va predicando el reino de Dios, que trata de iluminar las realidades de la tierra. Fue inleresante ver ese grupo de mujeres de diversas congregaciones que se sienten 
tan unidas en el trabajo pastoral" (27 de noviembre de 1979).

El 8 de noviembre de 1979 encontramos a Monseñor de paseo en las orillas del Lago de Coatepeque con los sacerdotes de la vicaría de la Resurrección. La conversación giró sobre la situación planteada después del golpe. E] mismo les preguntaba. En concreto, habiendo entre ellos un sacerdote que era capellán militar, preguntó cómo ayudar a una verdadera purificación del ejército y de los cuerpos de seguridad. Más aún, les contó que esa noche iría a verlo el director de la Guardia Nacional, Vides Casanova, y deseaba sugerencias concretas.

Monseñor concelebró con las generaciones de sacerdotes que cumplieron sus bodas de plata sacerdotal durante su arzobispado. Después de la liturgia compartió con todos ellos un largo rato. Sus responsabilidades pastorales a veces le permitian "profundos respiros" pastorales que to alejaban de las tensiones de San Salvador. Una de estas ocasiones se encuentra relatada en el diario, cuando fue a presidir la celebración de los 60 años de matrimonio de los padres de un párroco en San José Villanueva, "un conjunto precioso para una tarde pastoral para hablar de la Virgen, de la santidad del matrimonio y de la fidelidad, del don de la vida, de la fecundidad santa. Temas que en un ambiente de sencillez... habia también muchos niños que habían llegado de la escuela, llevada en pleno. Un tema con lenguaje pastoral sencillo y un saludo, a la despedida, a todos dándoles la mano, deja en el alma una tranquilidad de estar enraizado y encariñado con un pueblo que sabe corresponder" ( 31 de mayo de 1979).

En febrero de 1980, cuando estuvo en Bélgica para recibir el doctorado honoris causa de la Universidad de Lovaina se entrevistó con las familias de sacerdotes y religiosas que trabajaban en la arquidiócesis, "Tue emocionante la acogida cariñosa que me brindaron y la convivencia que compartimos, primero en la capilla, donde leímos un texto del evangelio acerca de la misión de los enviados de Dios a predicar su evangelio, y una homilia en que tráté de comentar los sentimientos que alli nos unían y el recuerdo de los seres queridos, que están allá lejos y que son el producto de estas familias tan unidas, tan acogedoras, lan cristianas. Compartimos luego una sabrosa merienda, en la que tuve otra nueva ocasión de saludar uno por uno y de fotografiarnos en grupos familiares. En fin, que fue una tarde inolvidable, de mucho corazón y de mucho sentido cristiano" ( 3 de febrero de 1980). Al regresar a la arquidiócesis fue a almorzar con los sacerdoles belgas "...y asi cumpli ya este primer día de trabajo con uno de mis principales propósitos, de compartir más mi vida, aun en forma más privada, con los queridos sacerdotes de la diócesis. Fue una conversación muy fraternal en la que pude expresar también mis temores acerca de las críticas que se hacen del trabajo de los belgas, pero que tratándolos de cerca es un trabajo muy cristiano, pero que merece mucho cuidado de parte del pastor de la diócesis..." (3 de marzo de 1980).

Después del golpe del 15 de octubre de 1979 llamó a todos los sacerdotes que estaban fuera del país; les dijo que los necesitaba mucho y que ya podian entrar sin temor. Pero siempre los dejó en libertad de decidir por sí mismos. Dialogó pastoralmente con quienes estuvieron a su alcance (11 de enero de 
1980). A un diácono que se quería ir de la arquidiócesis alegando desacuerdo con la línea pastoral "traté de convencerlo de su error y de que advirtiera también cómo en nuestra diócesis hay un sano pluralismo, donde caben todas las tendencias con tal que sean legítimamente pastorales." Pero no pudo convencerlo. Ante la insistencia del diácono le pidió el nombre del obispo que lo recibiría para informarlo y descargar su conciencia (21 de enero de 1980). A un sacerdote también en desacuerdo con la línea pastoral de la arquidiócesis y con problemas con el resto del clero, pero que deseaban permanecer en la diócesis, le explicó con franqueza "la línea pastoral que aquí tenemos que seguir y que no me gustaría apresurar una resolución (sobre su futuro destino). Sólo le dije que me alegraba de que volviera y que estábamos dispuestos a seguir conversando" (18 de julio de 1979).

Uno de sus últimos proyectos con respecto al clero consistía en fundar una casa nacional para recoger a los jubilados, para descansar y recuperarse de las enfermedades, para estudiar y dar cursos "me parece que la mano de Dios va señalando este camino que tanto he deseado," comentó (22 de marzo de 1980).

Después de los asesinatos de sus sacerdotes se encontró con sus respectivas comunidades para animarlas a continuar y para recoger la memoria de los mártires de la arquidiócesis. Con los amigos del P. Ernesto Barrera se reunió el 11 de diciembre de 1978 para "recoger testimonios de las actitudes y actuaciones del P. Neto y (en) todos hay un gran sentido de agradecimiento. Un sentimiento muy profundo por su muerte y todos expresan elogios del trabajo cristiano del Padre Neto. Ninguno de ellos manifiesta una actitud o unos consejos violentos en este sacerdote al que se ha tratado de calumniar por parte de la información oficial" (11 de diciembre de 1978). A los 40 dias de los sucesos de El Despertar dijo misa en la comunidad con asistencia de las familias que habían perdido a sus hijos. Lo impresionó mucho cuando se entregaron rosas rojas a las madres y al padre de Octavio Ortiz, "en mi homilía... agradeci a las familias el habernos dado esos temples de muchachos, a los que Dios escogió para ofrecer el supremo testimonio del amor" (2 de marzo de 1979).

Después del asesinato del P. Rafael Palacios, sobre quien habia "algunas dudas y algunos prejuicios," comenzó a tratar de recoger testimonios sobre su vida y comentó cuán maravilloso era conocer de cerca a sus sacerdotes. Su primera conversación la tuvo con varias personas que se presentaron en el arzobispado pocas horas después del asesinato, "creo que enseña mucho esla reflexión de familia que hicimos en una sala del arzobispado" (20 de junio de 1979). El 24 de junio de 1979 Monseñor conversó con la familia del padre Palacios, "me hicieron revelaciones muy importantes que esclarecen algunos aspectos del asesinato del Padre, de su modo de ser y de su línea pastoral. Me parece que estamos frente a un caso de un sacerdote que no ha sido comprendido y que ha dejado mucha trascendencia en su trabajo pastoral, sobre todo, en las comunidades eclesiales de base" (24 de junio de 1979). El 28 de agosto cenó con las comunidades formadas por Rafael Palacios, "lodo lo saturó su recuerdo en testimonios muy bonitos de un hombre que en forma oculta pudo hacer tanto bien..." (28 de agosto de 1979).

El 13 de julio de 1979 se reunió con las familias de los cinco sacerdotes del 
clero secular asesinados, exceptuando la de Barrera, "fue edificante el espiritu de perdón y de llamamiento a la conversión..." (13 de julio de 1979).

Monseñor también estuvo muy cerca de los religiosos y las religiosas de la arquidiócesis. En el diario hay frecuentes testimonios de estos repetidos contactos, comidas, descansos, celebraciones de todo tipo, etc. El tenia detalles para con los religiosos. Las veces que estuvo en Roma visitó las casas generalicias de aquellas ordenes y congregaciones que trabajaban en la diócesis y con las que él tenia mayor contacto. Les llevaba noticias de San Salvador y traia correspondencia de Roma, la cual entregaba cumplida y personalmente al retornar. Con las religiosas tuvo delicados detalles personales. A las que trabajaban directamente en la pastoral las admitió a la reunión del clero y les dió un lugar destacado en la liturgia.

No con todos los religiosos se llevó bien. El 21 de abril de 1978 tuvo una conversación con el provincial de una congregación dedicada exclusivamente a la enseñanza a quien le manifestó francamente la actitud negativa de algún religioso de su congregación, quien había manifestado poca confianza en la pastoral de la arquidiócesis y lamentó las actitudes del colegio que no sintonizaba con los ideales pastorales arquidiocesanos, "la reunión terminó muy positiva, después de decirnos con claridad muchas cosas." Pero las cosas siguieron igual, lo que a Monseñor le molestó profundamente. En concreto, la falta de sensibilidad de este colegio y de otro, también llevado por religiosos, ante el asesinato de los sacerdotes. En el diario dijo que esta falta de sensibilidad ante la muerte del padre Rafael Palacios le había causado "un sentimiento casi de frustración;" pues los dos colegios católicos, mientras se estaba velando el cadáver del sacerdote desarrollaron un juego de baloncesto programado con anticipación como si nada hubiera ocurrido (23 de junio de 1979). Días antes había estado conversando de nuevo con el provincial y algunos religiosos de uno de estos colegios "quienes se quejaron del distancimiento con el arzobispo." Monseñor les expuso claramente "mis motivos, mis preocupaciones y ellos también hablaron con toda franqueza... se acordó intensificar las rela. ciones y procurar entre todos una pastoral verdaderamente de acuerdo con el arzobispado, al servicio de este pueblo..." (19 de junio de 1979).

En diversas ocasiones encontramos a Monseñor compartiendo fraternalmente con sacerdotes reducidos al estado laical con quienes conversaba animadamente acerca de sus preocupaciones y su situación, "sintieron mucha alegría de que yo estuviera con ellos y me propusieron su idea de crear una comunidad de base. Yo los animé... ya que, por el hecho de haberse retirado del ministerio, no dejan de ser miembros selectos de la Iglesia. Que el carácter sacerdotal que llevan les capacita para una obra de Iglesia, como es una verdadera comunidad eclesial de base desde la cual tienen que vivir la caracteristica misionera y santificadora de la Iglesia. Noto mucha sinceridad, mucha cordialidad y un gran sentido de adhesión a la jerarquia"' ( 9 de noviembre de 1979).

\section{e) Relaciones con el seminario y los seminaristas}

Monseñor se mantuvo muy cerca de sus seminaristas tanto a nivel personal como colectivo. Con frecuencia se reunía con ellos para dialogar sobre los 
temas más relevantes de la vida eclesial y de la realidad nacional. El 12 de abril de 1978 la conversación giró sobre la vocación sacerdotal, "les inculqué la belleza de una vocación vivida así como una obediencia al llamamiento de Dios y, por tanto, un esfuerzo para santificarse y vivir unido con Dios, y por otra parte, desde Dios, desde esa contemplación de Dios, procurar reflejarse con el pensamiento de Dios hacia un pueblo tan complicado y difícil como es el que les tocará dirigir espiritualmente cuando sean sacerdotes; o aunque no lo sean, como seglares que tuvieron la oportunidad de formarse siquiera unos años en el seminario" (12 de abril de 1978).

El día antes de salir para Roma, el 26 de abril de 1979, se reunió con los seminaristas a quienes "después de expresarles mi admiración por la vocación que el Señor nos ha dado (les dijo que) debían ser fieles y leales con esa vocación recibida de Dios." Posteriormente, los seminaristas le estuvieron preguntando sobre la pastoral de la semana santa. Por estas y otras referencias se ve que uno de los temas predominantes en estas reuniones era la vocación sacerdotal. Monseñor gustaba hablar a los seminaristas de este tema desde la propia experiencia personal y pastoral. El 13 de marzo de 1980 lo encontramos en una reunión similar con los del seminario menor. Primero les habló de las relaciones con el obispo, las cuales debían tener como supuesto fundamental la experiencia de la fe y la comprensión mutua. Luego vinieron muchas preguntas, "un diálogo interesante sobre la vocación en que llegamos hasta contar los origenes de nuestra vocación. Comencé yo por contar el mio y ellos también sintieron mucha confianza de contar por dónde el Señor los había llamado. Yo les pedi que hicieran un relato personal, ya que no habia dos vocaciones iguales y que serviría de mutua edificación" (13 de marzo de 1980).

Otro de los temas desarrollados en estas reuniones fue el de la politización del clero y de los seminaristas. Monseñor les comunicó sus temores y los exhortó a colaborar siempre en unidad con la Iglesia. En este sentido, les enfatizó la necesidad de formarse "desde su identidad sacerdotal, a lo que los llama su vocación. Fue una junta que me dejó completamente satisfecho al ver las inquietudes de los muchachos y también la oportunidad de dar el pastor sus orientaciones, tal como quisiera a sus sacerdotes" (18 de mayo de 1979). La problemática era real; de una reunión con la comisión arquidiocesana responsable de la formación del seminario sacó la conclusión de que habia "un problema de fondo y es el problema ideológico que está haciendo también algún estrago en algunas comunidades, donde se pierde el verdadero concepto de Iglesia. Trataremos de ser muy fieles al pensamiento teológico de la Iglesia y de iluminar..." (30 de noviembre de 1979).

El 1 de mayo de 1979 un grupo de seminaristas participó en la manifestación de los trabajadores, "clasc humana a la que cllos perlenecen," observó Monseñor. La dirección del seminario estaba escandalizada de la actividad política de los seminaristas y parece que amenazaba con expulsarlos. "Yo Trancamente no he visto que haya algún error. Unicamente les hice ver que dadas las circunstancias tanto del pais como especialmente de la Iglesia y del seminario y de nuestra arquidiócesis, sería prudente contar siempre con un asesoramiento de quienes puedan dirigirlos bien." Por esto último, Monseñor entend:a un diálogo constante con el obispo con franqueza y confianza. El, 
por su parte, trató de comprender "su inquietudes sin quitarles lo noble que estas inquietudes tienen, pero llamándolos a que sepan expresarlas para que sean eficaces testimonios al servicio de las justas reivindicaciones del pueblo que como sacerdotes o llamados al sacerdocio no pueden hacerse más que con un carácter plenamente evangélico" (24 de mayo de 1979).

Un tercer tema sobre el cual dialogaron en estos encuentros periódicos fue el problema intraeclesial, el rechazo de las otras diocesis a la linea pastoral y al pastor de la arquidiócesis. A través de estos contactos Monseñor fue viendo madurar a los seminaristas, lo cual le daba mucha alegria.

Así, pues, desde el seminario trató de educarlos en ese método pastoral tan suyo, el diálogo, "y dialogar con toda confianza sus problemas junto con su obispo. Yo los felicité y les dije que, tanto el contenido como la manera como lo habian hecho, me habia satisfecho y esperaba que se fueran formando bien para el sacerdocio, tal como lo quiere Dios en este tiempo" ( 3 de julio de 1979). Cenando con los seminaristas de tercer año trató de inculcarles más esa intimidad con el obispo para que la mantuvieran después cuando ya fueran sacerdotes (17 de agosto de 1979). De la experiencia con sus sacerdotes y de estas conversaciones con los seminaristas Monseñor dijo que se habia dado cuenta "qué necesario es que el pastor conozca más intimamente a sus seminaristas" (13 de septiembre de 1979). Con este propósito, a mediados de septiembre de 1979, instaló una pequeña cocina y acondicionó un cuarto para descansar después de almuerzo en el arzobispado, "para poder dedicar las primeras horas de la tarde a este trabajo tan útil de orientar personalmente a los seminaristas" (13 de septiembre de 1979).

Al terminar una reunión con los dos seminarios sobre la mejor forma de integrarlos, Monseñor comentó, "me dió mucho gusto oir las conclusiones de su convivencia y sentir el espíritu de unidad que los anima para hacer del seminario... de la arquidiocesis una unidad compacta en el ideal hacia el sacerdocio" (17 de julio de 1979).

Las dificultades internas y externas no faltaban tampoco en esta área tan importante de la vida pastoral de la arquidiócesis. La postura de Monseñor respecto a los problemas internos para el diálogo constante con los seminaristas y con la dirección del seminario, la cual tendía más a las medidas autoritarias y verticales. Es decir, los miembros de la dirección querian resolvèr los problemas disciplinarios internos a base de expulsiones masivas. Monseñor, por su parte, trató de evitar estas medidas tan drásticas; su línea iba más por las comprensión, la paciencia y el dejar crecer la vocación hasta ver cuánto daba de sí en medio de las dificultades. El 19 de enero de 1979 participó en una reunión con la dirección del seminario para decidir la expulsión de 6 seminaristas, "pero sacerdotes párrocos y comunidades que conocen la labor de esos muchachos se oponen a este juicio del equipo formador y han pedido que intercedamos... estamos dispuestos a salvar la vocación de estos seminaristas, mientras no nos conste lo contrario" (19 de enero de 1979). Monseñor se fue a Puebla con esta preocupación. Al hablar por teléfono a San Salvador una de las cosas por las que preguntó fue por la resolución del caso de estas expulsiones. 
El 23 de agosto de 1979 volvió a intervenir en la dirección del seminario para evitar, una vez más, expulsiones masivas, "presionó" para que se tratara el caso con serenidad, es decir, dialogando. El conflicto surgio porque varios seminaristas participaron en los 3 dias de oración y ayuno, organizados en un templo capitalino por un sector del clero, sin contar con la dirección del seminario, !a cual probablemente les hubiera negado el permiso. "Naturalmente," comenta Monseñor, "se les exhortó a pedir perdón y a reconciliar y dialogar, en lo sucesivo no lomar actitudes por propia iniciativa"' (23 de agosto de 1979). Al analizar los informes de la dirección del seminario sobre 4 seminaristas que iban a ser ordenados diáconos y quienes presentaban "bastantes punlos negativos," Monseñor pensaba que "no es tan grave la situación, sino que faltaba un poco de comprensión para las inquietudes de nuestra arquidiocesis y de nuestra juventud." Antes de dar su respuesta afirmativa converso con los interesados los informes de la dirección del seminario (17 de diciembre de 1979).

Respecto a la formación pastoral necesaria en los seminaristas, Monsen̂or pidió ayuda a las vicarías de La Asunción y Flor Blanca. Para él, los seminarislas tenian que formarse "para ser servidores del pueblo bajo la inspiración de la Iglesia en cualquier ambiente que les toque trabajar, por eso, se incorporarán un poco más a la vida del seminario estos párrocos y procurarán que los seminaristas colaboren con ellos en esa zona tan dificil de la pastoral" (22 de mayo de 1978). Por otro lado, le consolaba mucho ver "cómo nuestros muchachos en el seminario compartieron la vida pastoral con las comunidades de base, se identificaron, pero llevandoles el pensamiento del evangelio y de su Iglesia" (26 de abril de 1979).

Las normas del seminario, según Monseñor, debian estar basadas en los documentos de Puebla. Para esto pidió un diálogo entre la dirección del seminario y la arquidiócesis, "el asunto es muy delicado y es necesario abordarlo con valentia porque el seminario es la esperanza de la arquidiocesis" (14 de septiembre de 1979). La delicadeza del asunto radicaba en las tensiones que se venian dando entre la forma cerrada y poco adaptada a la pastoral arquidiocesana que caracterizaba a la formación dada a los seminaristas y las lineas pastorales arquidiocesanas. Aparte de que los demás obispos estaban presionando fuertemente para que se mantuviera siempre una formación tradicionalista que excluía las últimas instrucciones del magisterio eclesiástico universal y regional.

En efecto, los demás obispos, contrarios a la pastoral arquidiocesana y a su pastor, querian expulsar a todos los seminarislas arquidiocesanos del seminario. Para ellos, la arquidiócesis era "el problema." Querían que el seminario sirviera sólo a sus seminaristas, cuando el edificio y los campos fueron construidos y cran mantenidos por la arquidiócesis y la colaboración desinteresada de los jesuitas, quienes lo dirigieron hasta 1972, cuando los mismos obispos los expulsaron de la obra. El 24 de abril de 1978, Monseñor dijo que Mons. Aparicio presentó a la nunciatura y a la congregación romana para la educición un informe "Iendencioso." La misma dirección del seminario se quejó porque no se le había tomado en cuenta, "este es cabalmente el mismo 
problema que yo lamento," comentó Monseffor en el diario. Parece que para entonces ya habia recibido un reclamo de dicha congregación y, además, una carta de Mons. Aparicio, donde lo acusaba de ser el culpable de la falta de disciplina en el seminario y de estar sembrando ideas izquierdistas entre los seminaristas (24 de abril de 1978).

El 3 de junio, Monseñor estuvo conversando con el rector del seminario para redactar un informe respuesta, "enérgico y científico," a las acusaciones de Monseñor Aparicio, "unas acusaciones tan superficiales y tan inspiradas en la mala voluntad" (3 de junio de 1978). El 14 de diciembre de 1979, la conferencia episcopal colmó la paciencia de Monseñor, quien se decidió a preparar "un buen informe" para Roma detallando como la conferencia episcopal no estaba prestando los servicios para los cuales había sido establecida y cómo existia "una tendencia casi personal contra el arzobispo y contra la arquidiocesis." Monseñor tomó esta decisión, cuando la conferencia episcopal, dentro de la cual se encontraba en clara desventaja, eligió a Mons. Aparicio como su encargado del seminario. También pensó que había llegado el momento de "hacer nuestro propio seminario y no estar siendo victimas de tantas injusticias de la conferencia episcopal" (14 de diciembre de 1979).

\section{Monseñor en Puebla}

Monseñor se preparó cuidadosamente para ir a Puebla. Antes del viaje se estuvo reuniendo con sacerdotes y laicos para asesorarse, "he recogido muchas experiencias y muchos conocimientos que respaldan mi actuacion como pastor en Puebla," es decir, a la conferencia de obispos latinoamericanos fue con conciencia de representar la experiencia pastoral arquidiocesana (13 de noviembre de 1978). Esto es importante porque Monsentor no fue a Puebla como representante elegido por la conferencia episcopal salvadoreña, sino como representante de un organismo del CELAM. Al principio no quería ir, pero sus asesores le aconsejaron que utilizara la oportunidad que le daba el desempefiar un cargo directivo en una de las comisiones del CELAM para asistir y representar a toda la arquidiócesis.

Los obispos salvadorefios se reunieron el 17 de abril de 1978 para estudiar el documento de consulta de Puebla. En esta reunión se hizo la elección del obispo que asistiría a la reunion. "Tengo la impresión," dijo Monseffor en el diario, "de que también en esta reunión de obispos existieron, antes de la reunión, algunas manipulaciones, ya que la elección del delegado pareció muy de acuerdo entre Monseñor Aparicio, Barrera y Alvarez, que dieron su voto por Monseñor Revelo ganando naturalmente, contra el voto de Monsefor Rivera, Revelo y mio." Mons. Revelo obtuvo 3 votos y Mons. Rivera (el de Revelo y Romero) y Monseñor obtuvo sólo un voto (el de Mons. Rivera, "sin duda').

Lo mismo sucedió cuando se pasó a la elección del sacerdote del clero diocesano que iria a Puebla, "el mismo bloque elige a Monseñor Fredy Delgado. Confio en la inspiración del Espiritu Santo que estará por encima de todas las intrigas humanas y que la reunión de Puebla será verdaderamente como un 
Medellin, un pentecostés para nuestra América a pesar de todos los temores e intrigas de los hombres" (17 de abril de 1978). Un mes más tarde, la conferencia episcopal se volvió a reunir para recoger la reflexión de las diócesis sobre el documento de consulta. Monseñor comentó que San Miguel no presentó nada y que el informe más completo era el de la arquidiócesis (26 de mayo de 1978).

Las páginas del diario dedicadas al desarrollo de Puebla no dicen mucho sobre la reunión misma. Monseñor se detuvo mucho en la formalidad externa de la conferencia detallando los nombres de los participantes, los temas, las comisiones, los actos litúrgicos que tuvieron lugar, pero sin traslucir nada personal. En este sentido, al final de la con ferencia sólo observó que habia mucho optimismo, aunque había fuertes presiones de los obispos conservadores. El, sin embargo, esperaba que la buena comisión de redacción que había, mantuviera los ideales de una evangelización "muy a tono con las exigencias de nuestro pueblo" (11 de febrero de 1979). En este sentido, lo que mejor impresión le causó de Puebla fueron aquellos actos litúrgicos donde hubo participación popular. Se sintió muy a gusto durante la primera concelebración en la basílica de Guadalupe, en la ciudad de México, presidida por el Papa. El ya habla ido privadamente a orar a la basílica al llegar a la ciudad; en realidad, fue lo primero que hizo (27 de enero de 1979). También se entusiasmó con la misa presidida por el Papa al aire libre en Puebla, "las porras, el entusiasmo típico de esta ciudad de Puebla se desbordó maravilloso hasta las lágrimas." Lo único que lamentó fue el no haber previsto una forma más práctica de repartir la comunión, pues sólo se permitió que un grupo de seminaristas comulgaran de las manos del Papa (28 de enero de 1979). Calificó de feliz ocurrencia la de "llevar a los obispos a las diversas parroquias... era muy bonito ver las camionetas que venian de cada parroquia con grupos de fieles, muchos de ellos jobvenes, para acompanfar a los pastores a visitar y a compartir la mañana, la Eucaristía y el almuerzo..." (4 de febrero de 1979).

Uno de los aspectos más relevantes en el diario durante los días que permanecio en Puebla, fue su contacto con la prensa. Ya en el aeropuerto tuvo una primera conferencia de prensa donde le preguntaron por el asesinato del padre Octavio Ortiz y la persecución a la Iglesia. En estas primeras declaraciones desmintió públiçamente al general Romero, quien también habia estado de visita a México y había declarado que en El Salvador no se perseguía a la Iglesia. Entre el 22 y 24 de enero se estuvo reuniendo en privado con diversos periodistas, pero el 24 tuvo una gran rueda de prensa, "No esperábamos tanta gente, pero me alegré de tener en frente unos 50 periodistas... con una serie de preguntas muy interesantes, pero que yo notaba como una simpatía especial para la Iglesia y hasta en las preguntas habia respeto y sinceridad. Comencé agradeciendo esta oportunidad de ampliar mi voz en favor de los que no tienen voz y de hacer conocer en la amplitud de sus mensajes el pensamiento de una Iglesia que quiere ser fiel al evangelio. Les describi la situación económica, social y política de mi país y cómo en ese ambiente tan difícil es donde la Iglesia trata de realizar su misión profética, que va a despertar la conciencia de los salvadoreños, no para que sean masa, sino que sean hijos de Dios, formando comunidades donde reine el verdadero amor y por eso la Iglesia denuncia todo aquello que destruye la dignidad del individuo y sobre todo destruye la capaci- 
dad de construir un pueblo sobre bases de amor, justicia y paz" (24 de enero de 1979).

El 9 de febrero, a pesar de estar con malestar en un ojo, atendió a una conferencia de prensa preparada con anticipación. En esta ocasión se presentó acompañado de dos sacerdotes expulsados del país quienes habian estado trabajando en la arquidiócesis. La conferencia "resultó un verdadero homenaje a mi arquidiócesis... invité a compartir las experiencias pastorales de una arquidiocesis que puede dar testimonio del sufrimiento. Así como también de la fecundidad del sacrificio... Y en ciertos momentos hubo aplausos muy entusiastas, sobre todo a la salida en que se coreaba 'Nobel,' 'Nobel.' Varios quisieron todavía continuar entrevistas privadas. A los que traté de dar complacencia..." (9 de febrero de 1979).

Al final de su permanencia en Puebla resumió de la siguiente forma estos frecuentes y fecundos contactos con la prensa, "me he hecho amigo de la mayoria de los periodistas" (14 de febrero de 1979).

Estando en Puebla salió a la prensa el conflicto existente dentro de la conferencia episcopal salvadoreña. No fue Monseñor quien hizo público el conflicto, sino Mons. Aparicio, obispo de San Vicente. El 3 de febrero la prensa publicó unas declaraciones de este obispo que Monseñor resumió en el diario asi, "echa la culpa de la violencia en El Salvador a los jesuitas y denuncia que hayan venido a Puebla a defender la posición del arzobispo que según (la) declaración es indefendible, ya que en sus actuaciones ha llegado hasta las ofensas personales del gobierno, lo cual es falso y los jesuitas, cuyo Superior General, el Padre Arrupe, está entre nosotros, han manifestado sus resentimientos por unas predicaciones tan peligrosas..." (3 de febrero de 1979). De inmediato Monseñor se reunió con el padre Arrupe para discutir qué hacer frente a estas acusaciones, "no tanto para defendernos en lo personal, sino por el bien de la Iglesia y para evitar peligros con esta declaración..."

El 5 de febrero, preocupado por el impacto que estas declaraciones pudieran haber tenido en San Salvador, llamó por teléfono. Ese dia comentó, "francamente es una lástima porque se está explotando... contra la Iglesia y es peligrosa situación para los padres jesuitas..." Uno de sus vicarios generales le informó que trataría el asunto en la próxima reunión del clero, "le autoricé, invitándole únicamente a que no provocaran más de lo que está la situación actual."

Monseñor no perdió la serenidad ante estas declaraciones. En este y en otros casos nunca quiso entrar en la polémica pública con Aparicio; prefirió callar y tener paciencia. Por eso canceló una rueda de prensa que había programado para el día 7 . No consideró prudente asistir, no obstante, saber que lo estaban esperando porque estaban muy recientes las declaraciones de Mons. Aparicio (7 de febrero de 1979). En los círculos internos de Puebla le informaron otros obispos que las declaraciones de Mons. Aparicio habian causado “muy mala impresión." El, por su parte, pidió "al Señor que estemos muy superiores a estas miserias humanas de la Iglesia y así lo comuniqué este día al transmitir por teléfono a la YSAX el diálogo de todas (las semanas)" (7 de febrero de 1979). 
En este contexto cenó con los teblogos consultores externos el 8 de febrero. Para Monseñor este encuentro fue "un gran consuelo cuando pude informarles la soledad que siente un pastor cuando quiere ser fiel a todas las consignas que nos da el evangelio, el Vaticano II, Medellín y como compañeros como los que han venido conmigo de El Salvador a Puebla piensan distintamente." Este testimonio de soledad personal entre un episcopado causó impacto sobre los asistentes a la comida. De aquí salio la sugerencia de escribirle una carta de solidaridad; lo mismo se hizo con los obispos de Nicaragua y Guatemala.

Al regresar a la ciudad de México lo estaba esperando de nuevo una parte de la realidad salvadoreña, los salvadoreños en el exilio. Siempre que Monsenor salió de El Salvador se encontró con estos grupos que lo buscaban para saludarlo y oir, aunque fuera una breve palabra de consuelo y de esperanza. El 14 de febrero estuvo con quienes se habían tomado la embajada de México, "lo mismo que otros paisanos que sufren en México la pena del destierro desde hace ya mucho tiempo. Platicamos mucho para darles aliento en su situacion y vemos que el espiritu es muy bueno y se mantienen optimistas. Tratamos de ayudar más bien a los recién llegados..." (14 de febrero de 1979). Esta última alusión se refiere a que en esos días estaban llegando más exiliados a quienes él personalmente, en colaboración con los demás, trató de encontrarles alojamiento. El 15 en la noche volvieron a llegar los exiliados "a los cuales traté de darles palabras de aliento y ofrecerles la ayuda que, dentro de mis capacidades, les he podido ofrecer y les seguiré ofreciendo - sin ningún color políticosimplemente con un sentido cristiano de fraternidad y de caridad" (15 de febrero de 1979).

Esa mañana, la última que pasaba en la ciudad de México, regresó solo a la basílica de Guadalupe, "donde, sin prisa, dediqué el resto de la mañana a la oración terminando con la celebración de la misa."

Su regreso a San Salvador, el 16 de febrero fue apoteósico. Lo primero que lo sorprendió fue la atención recibida en ei aeropuerto de parte de las autoridades, las cuales habian permitido que un grupo de sacerdotes lo esperara en la escalera del avión. El mismo gerente del aeropuerto gestionó el pasaporte y le ofreció el salón diplomático, "pero veía yo en el aeropuerto mucha gente que habia venido para esperarme y no acepté el carro para salir inmediatamente, sino que sali a pie para saludar a todos los amigos..." Del aeropuerto se dirigió directamente a la catedral, donde se lo esperaba para presidir la eucaristía, "estaba ya repleta y cuando se dieron cuenta de mi arrivo un sonoro aplauso y vivas que fue creciendo porque la muchedumbre también iba creciendo." El canciller del arzobispado le dio la bienvenida, recibiendo muchos aplausos del auditorio, "porque interpretó en forma sencilla, pero emotiva lo sentimientos de aquella catedral llena de gente."

En su homilia habló de lo que Puebla significaba para la arquidiócesis. He aquí el resumen de sus propias palabras tal como está en el diario: "yo fui en Puebla el representante de una diócesis en oración y, les inculqué mucho, asi como les agradeci la oración que yo sentia tan fuerte, que siguieran orando para que esto fuera la mayor fuerza de nuestra diocesis... yo en Puebla llevaba el testimonio de una diócesis en una línea de pastoral muy de acuerdo con lo que 
se estudió... y me referí a los numerosos testimonios de la vida de la arquidiócesis que yo tuve tan presente en la reunión. Agradecí el trabajo pastoral del vicario general, de los vicarios, de los párrocos, de las comunidades que durante mi ausencia, sin embargo, continuaron llevando una vida eclesial muy rica. Y me alegré de lo que pude contar en Puebla del testimonio vivido en mi arquidiócesis... y el tercer pensamiento, lo que yo traigo de Puebla para la arquidiócesis, la experiencia, la riqueza, la amistad de numerosos pastores y diócesis del continente y del mundo. La gente me interrumpió varias veces con cariñosos aplausos..." (16 de febrero de 1979). Al terminar la eucaristía, Monseñor salio "entre las aclamaciones del pueblo para saludar en la calle, porque había gente hasta la calle frente a catedral. Fue un momento muy cariñoso de saludos, de abrazos y hasta de besos de algunas personas, dándome una bienvenida que yo sentia casi como una familia, un hogar en el cual me encontraba tan a gusto" (16 de febrero de 1979).

Dos meses más tarde, Monseñor asistió a la reunión de la Conferencia Episcopal Centroamericana (CADAC), realizada en San José (Costa Rica), para estudiar los documentos de Puebla y su aplicación. En el diario se le nota aburrido durante las exposiciones doctrinales, pero cuando se reunieron por conferencias episcopales para discutir la aplicación del documento se muestra mucho más animado. Sin embargo, ante su posición "de presentar con toda franqueza nuestra realidad eclesial y nacional, comenzando por la división de los obispos y por los diversos problemas de relaciones con el gobierno y de los que han sufrido verdaderos martirios por la Iglesia y otros aspectos que son materia conflictiva de nuestras relaciones episcopales," volvieron a salir los conflictos internos dentro de la conferencia. Los demás obispos lo acusaron "como si yo fuera el culpable de divisiones y de malestares, hasta de la politización del clero." Monseñor Luis Chávez, antiguo arzobispo y quien también asistió a la reunión, después le comentó, "fue duro el bombardeo" (16 de abril de 1979).

\section{Monseñor y la crisis del país}

Monseñor había roto relaciones oficiales con el gobierno del general Romero por la persecución abierta contra la Iglesia y la represión desatada en contra del pueblo; aunque mantuvo algunos contactos privados con algunos altos funcionarios del gobierno, tal como se ha visto antes. Una de las manifestaciones más públicas de esta ruptura de relaciones fue la promesa pública de no asistir a ningún acto oficial del gobierno ni permitir que el gobierno asistiera oficialmente a la catedral, y la cumplio.

Cuando murió Pablo VI, la arquidiócesis se preparó para celebrar el funeral junto con el pueblo en la catedral. En este contexto respondió a una consulta del secretario de la nunciatura sobre esta celebración recomendándole seguir la costumbre del nuncio de celebrar estas ocasiones en la nunciatura, pero evitando "tanta publicidad en la que parece que al gobierno lo que más le interesa es la publicidad en periódicos que la oración y el homenaje al Santo Padre" (2 de octubre de 1978). Aplicando el mismo criterio, el 20 de noviembre de 1978, acompañado de Mons. Rivera, concelebró en la catedral de San Miguel la 
vispera de la fiesta de Nuestra Señora de La Paz, pues "maftana, por la presencia de las supremas autoridades civiles, no tendriamos oportunidad de hacer un homenaje más íntimo como el que queriamos y porque estas autoridades más bien aprovechan las circunstancias para sus publicaciones y no les interesa el homenaje religioso..." (20 de noviembre de 1978).

\section{a) La primera junta de gobierno}

El problema más dificil surgió con la primera junta de gobierno, después del golpe militar del 15 de octubre de 1979, pues entonces algunos llegaron a desconfiar y a dudar de su integridad de pastor. El origen de estas desconfianzas estaba en que Monseffor esperaba mucho del golpe militar y de su proclama.

Desde el 10 de octubre de 1979 estuvo a la expectativa. Esta fue su primera actitud. En efecto, ese día se reunió con sus asesores eclesiásticos y seglares para reflexionar sobre cuál debia ser la actitud de la Iglesia en el caso de un golpe, "fueron muy prudentes en aconsejarme que, ante todo, estuviéramos a la expectativa y que aun, en el mejor de los casos, habria que esperar el sesgo que tomaban las cosas y no adelantar ninguna muestra de solidaridad que pueda comprometer"' (10 de octubre de 1979).

El mismo día del golpe, el 15 de octubre, se fue a Cojutepeque a participar en un concurso bíblico en la escuela parroquial de esa población, "estaba yo tenso porque sabía lo que me habían anunciado en la mañana y no veía ningún resultado efectivo (al regresar de Cojutepeque), pensé que se encaminaba al fracaso..." (15 de octubre de 1979). Al conocer que el golpe estaba consumado, por la noche de ese día se volvió a reunir con sus asesores, "me dijeron que era conveniente esperar el rumbo de las cosas, pero que pastoralmente podia adelantarse una exhortación al pueblo llamándolo a la cordura para evitar cualquier extremismo de derecha o de izquierda, y al mismo tiempo, un llamamiento al nuevo gobierno para esperar que el cumplimiento de sus promesas daría la credibilidad que el gobierno ha perdido en el pueblo."

En el diario, Monseñor dijo que notó en el ambiente cierto "respiro de esperanza," aunque también temor por tratarse de un golpe de los militares, "esperamos en Dios que se sepa comprender la buena voluntad y que entre todos busquemos salir de esta crisis..." (15 de octubre de 1979). El personalmente temía "la reacción de las fuerzas de izquierda que ya llamaban a la insurrección popular. También se teme por la extrema derecha que se sentirá provocada por el manifiesto del nuevo gobierno que promete muchas reformas..." (ibid.).

El 17 de octubre, Monseñor ratificó la posición de la Iglesia en la YSAX, "lạ Iglesia no está comprometida con ninguna coyuntura politica concreta, sino que siempre mantiene su independencia para poder aprobar lo bueno y criticar lo malo" (17 de octubre de 1979).

Desde el principio, sin embargo, este compás de espera que bien podría ser intepretado como un apoyo a los militares golpistas, estaba condicionado a la depuración del ejército, a cambios profundos de estructuras y a la participa- 
ción del pueblo, admitiendo todas las opiniones en lo que él llamó una verdadera apertura democrática. En este sentido, su propósito era que la Iglesia expresara el sentimiento y las esperanzas populares (10 de octubre de 1979).

Asi se los dijo a los dos coroneles, Majano y Gutiérrez, quienes lo visitaron junto con el comité cívico-militar el 16 de octubre. Los coroneles llegaron a agradecer sus intervenciones públicas para pedir calma sobre todo a la izquierda, la cual habla llamado a la insurrección popular. Pero al mismo tiempo aprovechó la ocasión "para darles el parecer de la Iglesia, sobre todo, que manifestara con hechos, los más sensibles al pueblo serían la amnistía general y la información sincera acerca de los desaparecidos, el retorno de los exiliados; etc. Me prometieron hacer todo... se nota en ellos todavía la inexperiencia de un cargo sumamente dificil, asumido casi en forma improvisada" (16 de octubre de 1979). Monseñor, pues, estaba muy claro en cuanto a lo que queria, hechos que demostraron la buena voluntad de los militares golpistas; para declaraciones era suficiente la proclama. Y hechos sensibles al pueblo que era quien tenía que decidir, en definitiva, sobre la bondad o maldad del nuevo proyecto político. Su última observación sobre la inexperiencia de los militares no debe pasarse por alto porque, en parte, el proyecto fracasó por esa razón.

El apoyo condicionado no impidió que Monseñor denunciara en público y en privado la represión de los cuerpos de seguridad en Mejicanos y en Soyapango, ocurrida el 16 de octubre. Personalmente llamó a los militares para anunciarles que les estaba enviando una delegación para que le dieran los datos de primera mano sobre lo ocurrido, lo cual "puede desprestigiar la esperanza que en ellos puede poner el pueblo. Y a insistir en que dieran muestras de que los anima la mejor voluntad y que lo demostraran con hechos" (16 de octubre de 1979). Diez días más tarde repitió lo mismo al coronel Gutiérrez, quien llegó a comunicarle las dificultades que estaban encontrando para informar sobre los desaparecidos; despues de oir el informe, Monseñor comentó que había manifestado "con toda claridad nuestra preocupación si no se resuelve este asunto a satisfacción del pueblo, este asunto tan delicado" ( 26 de oclubre de 1979).

Monseffor animó personalmente al rector de la UCA, Román Mayorga, a aceptar formar parte de la nueva junta de gobierno, junto con los dos coroneles. Para ello le dio los siguientes criterios, "le dije que él era una persona de confianza, que daría confianza a un gran sector del pueblo y dada su espiritualidad cristiana y sus conocimientos académicos como rector de la UCA, era el hombre indicado para dar un apoyo racional al movimiento que hasta ahora era solamente militar. En un gesto de humildad, el ingeniero Román Mayorga me dijo que sentía en mí la voz de Dios y que se comprometía. Yo también le dije que no era un compromiso incondicional, que si se dieran inconvenientes, él mismo tendría que salirse y si yo me daba cuenta de ello, yo mismo se lo diria. Se arrodillo y me pidió la bendición. Y creo que es un hombre en el cual podemos confiar plenamente, que lleva una representacion sincera del pensamiento de la Iglesia al dificil campo de la política (17 de octubre de 1979).

Ante la rebeldía de la izquierda, Monseñor continuó apoyando a Román Mayorga en la junta de gobierno, aunque "lo noté sumamente cansado y muy 
preocupado de la situación... pero traté de infundirle ánimo y de decirle que la responsabilidad del momento era grande y que Dios tenía que ayudarle..." (25 de octubre de 1979). El 20 de noviembre cenó con él y conversaron sobre los planes del gobierno con optimismo, "yo también sentí que mi esperanza en este cambio, a pesar de las deficiencias tan enormes del principio y de las criticas de la oposición, es una esperanza fundada," apuntó Monseñor en el diario. Pero el 19 de diciembre ya lo encontró lleno de temores y de dudas porque creía estar colaborando con un gobierno represivo. Monseñor, no obstante apunto, "le animé porque a pesar de esta represión que se nota hay también una altura que busca soluciones justas por medios más inteligentes y que en ese nivel estaba él y que sería una lástima ir viendo cómo se desprendian de ese esfuerzo los civiles en quienes tenemos mucha confianza, aunque esto no supone aprobación de la junta, sino una esperanza de poder encontrar caminos que no sean los violentos y de la sangre" (19 de diciembre de 1979).

Esta postura defendida y mantenida en privado en sus relaciones con el ingeniero Mayorga, Monseñor la defendió en su homilia del domingo 11 de noviembre en la cual trató "de ser muy justo entre la situación de la junta de gobierno que nos ofrece una verdadera esperanza, que algunos no quieren ver, pero que es mi deber alimentarla, y las perspectivas de la oposición de izquierda, que es cada dia más intransigente y que llega en los grupos armados hasta violencias que no se pueden tolerar" (11 de noviembre de 1979).

Por otro lado, las condiciones que estaba exigiendo que se manilestaran con hechos provocaron una visita del coronel Majano, del ministro de defensa Garcia y de otro militar no identificado, quienes llegaron al hospitalito "con gran aparato de guardaespaldas y detectives, que no deja de ser molesto." Inicialmente los militares llamaron a Monseñor a casa presidencial, pero él se nego a entrevistarse con ellos ahí para que su presencia no fuera mal interpretada. Para Monseffor el tema de la conversación resultó, como casi todos, muy interesante, pues estaban preocupados por la crítica que la YSAX habia hecho acerca del nombramiento del director de la escuela militar por sus actuaciones en el régimen del general Romero, cuando se desempeñó como jefe de información de casa presidencial, es decir, "responsable de las distorsiones de noticias, de campanas calumniosas contra la Iglesia, de la falsedad y de la mentira que es lo que se difundia desde casa presidencial." Cuando Monseñor recordó a los militares estos antecedentes, ellos trataron de defenderlo, pero "nosotros mantuvimos nuestra posición, que si no habia drasticidad en cambiar la figura del militar en el pais, este golpe de Estado no tendría resultado y el pueblo sufriría un nuevo fracaso. Insistimos también en la forma cómo se nombró al ministro de defensa, que estaba presente, porque lo nombraron sólo los militares cuando todavía no estaban los civiles. Al coronel Garcia... se le ocurrió decir ahl delante de nosotros... que él renunciaba en ese momento al ministerio mientras los civiles no ratificaron el nombramiento... También aproveché para denunciar los atropellos que la Iglesia está recibiendo más bajo este nuevo régimen y la apariencia de represión que el pueblo siente con los operativos militares... Ellos trataron de explicar que están depurando, mentalizando con ideas nuevas, pero que es diffcil el trabajo y nos pedian comprensión para esperar..." El diálogo, que Monseñor en el diario calificó de "tan cordial," 
concluyó con una tasa de café ofrecida por las religiosas del hospitalito y tomada en un ambiente muy cordial, aunque no por eso menos sincero y franco (19 de octubre de 1979). Monsefior anotó en el diario que, desputs de esta entrevista, la cual concluyó hacia las once de la noche, se quedó "estudiando mi homilia hasta las cuatro de la mafnana." Era un sábado.

El 10 de diciembre lo llegaron a ver dos militares, quienes le confirmaron sus recelos respecto al ministro de defensa, "un aliado con el pasado y que hace peligrar la mistica de renovación que tiene la juventud militar." Monsehor aprovechó la conversación para ratificar su postura prudentemente, "el apoyo que la Iglesia da a todo lo justo y a todo lo renovador y exhorté a ellos que eran los protagonistas de este momento provisional en el gobierno y que hiciera según su conciencia. Prometieron seguirme visitando otros militares que, según me dijeron, tienen mucha fe en mi palabra. Yo trataré de mantener siempre esa incolumnidad de la línea pastoral..." (10 de diciembre de 1979). Ya el 20 de diciembre llegaron a verlo otros dos militares con "bastante pesimismo... lástima, porque este decaimiento de ánimo puede ser fatal en hombres que deben empuñar hoy con mucho valor la situación, precisamente, porque es diffcil" (21 de diciembre de 1979).

Una semana más tarde, el 27 de diciembre, hizo constar en el diario que se encontraba otra vez a la expectativa de la crisis. El 28 de diciembre canceló todos sus compromisos pastorales, "que eran múltiples para estar a la expectativa de la crisis gubernamental. Todos han comprendido que mi papel es ahora al servicio de estos intereses y que no podía moverme de mi sede" (28 de diciembre de 1979). El 31 de diciembre, mientras desayunaba con el democrata cristiano Fidel Chávez Mena, lo estaban esperando dos militares jóvenes, miembros del Consejo Permanente de la Fuerza Armada, a quienes "con toda franqueza les advertí los riesgos y las cosas que me parecia habia que enmendar para superar la crisis del enfrentamiento con los ministros civiles" (31 de diciembre de 1979).

A estas alturas de la crisis Monseñor tomó una determinación audaz. Según sus palabras, el ministro de salud le propuso convocar a las partes en conflicto a un diálogo delante de la Iglesia, "después de analizar esta propuesta, me pareció que habia que prestar este servicio." Suplicó al ministro convocar a los ministros civiles, mientras él convocaria a los militares. La sesion sería el 2 de enero en la biblioteca del seminario. La razón profunda que motivó esta decisión suya era "orientar y decir que, ante todo, vean al pueblo, al que hay que servir" (1 de enero de 1980). En esos momentos estaba más preocupado por los civiles que por los militares.

El 2 de enero amaneció "muy preocupado porque me toca orientar esta junta tan trascendental, pero cuento con las oraciones de los enfermos, de las religiosas y de todos aquellos que se han dado cuenta del momento trascendental..." Por una confusión acerca del sitio del encuentro, los militares se presentaron con bastante retraso; cuando llegaron al seminario no querían entrar a la sala donde los esperaban los ministros civiles. Alegaron que deseaban hablar antes con Monseñor, "como que no habian entendido que iban a dialogar con los civiles y estaban renuentes. Yo les dije que prevaleciera el díalogo en bien 
del pueblo y que era necesario hablar y yo les había expresado claramente que se trataba de una junta con los civiles." Finalmente, el coronel Gutiérrez dio el primer paso y subieron a la segunda planta donde está la biblioteca. Entonces, Monseñor, según su recuento de los sucesos en el diario, tomó la palabra "y les motivé mi papel de pastor, representante de la Iglesia y de salvadoreño, representante de un gran sector del pueblo para pedirles en nombre de la Iglesia y del pueblo que llevaran a cabo un diálogo franco, sincero y que pudieran buscar una solución al servicio del país. Que no fuera dar un nuevo sentido de frustración a este pueblo ya sufrido. Me atendieron con respeto. Yo les agradeci y les invité a abrir el diálogo, exponiendo el fondo del problema, el conflicto, buscando luego las muchas convergencias que hay entre los dos sectores en conflicto y finalmente, señalando las divergencias para tratar de superarlas" ( 2 de enero de 1980).

Y continúa el relato del diario, "...el diálogo se abrió muy franco... aunque dada la impresión que los civiles no querían creer las promesas de los militares o no veían claras sus definiciones en pro de la proclama... Al final sinteticé esta reunión diciendo que yo veía un ideal, que es el proceso revolucionario que ellos tratan de fomentar. También veia dificultades y señalé todo lo que había oido en la discusión, como eran las ambiguedades de los militares y otros aspectos negativos contra el proceso de promoción de nuestro pueblo. $Y$ en tercer lugar, les dije que habia también oído caminos de solución, siendo el principal la sinceridad, la comunicación y todo aquello que fomente el acercamiento y entre estos caminos ofrecí el servicio de la Iglesia..." El parecer de Monseñor fue que el ambiente resultó cordial y que "el saludo final de despedida fue muy distinto del de la entrada, pero lamentablemente, mientras salíamos, se oía ya por la radio la respuesta..." (2 de enero de 1980). Como la respuesta de los militares era completamente negativa, se produjeron las primeras renuncias.

A continuación de las renuncias muchos de los funcionarios del gobierno fracasado pasaron a despedirse de Monseñor, "tuve visitas de algunos miembros del gobierno y me ha llenado de satisfacción la confianza que tienen con la Iglesia y algún bien que se puede hacer orientándolos desde la perspectiva pastoral" (3 de enero de 1980).

Dentro de los sectores eclesiales más próximos a las organizaciones populares esta actuación de Monseñor fue vista con recelos y desconfianzas. A él, personalmente, esto le causó mucha preocupación y lo deprimió el que no vieran la posibilidad abierta con el golpe del 15 de octubre. Este sentimiento se encuentra en el diario el 22 de octubre, una semana después del golpe, "me sentia muy abrumado por no encontrar comprensión en el ambiente acerca del momento político y de la actitud de la Iglesia." Una muestra de estas desconfianzas y críticas fue el diálogo que sostuvo con los seminaristas que se ordenarian el próximo año. Estos lo criticaron por el mensaje pastoral, el cual había sido transmitido por Radio Nacional, creían que había habido manipulación de la Iglesia y que ésta debía dar más testimonio de su independencia. Su primera reaccion ante las criticas de los seminaristas fue de alegría por su sentido crítico y por la franqueza de presentarle sus dudas, precisamente lo que estaba buscando en todos los miembros del clero. 
Pero a continuación, Monseñor abundó en las razones que tuvo para apoyar a la primera junta de gobierno tal como lo hizo diciéndoles "que yo era responsable de lo que habia escrito y dicho y no de cómo se manipula por uno $u$ otro sector. El hecho de haber salido en la cadena nacional no me parece algo compremetedor contra la Iglesia, toda vez que el mensaje que aHi se transcribió era, precisamente, mi pensamiento de autonomia, de independencia frente al nuevo gobierno, de apoyo prudencial, naturalmente, porque no es justo que se le critique y se le ataque sin haber dado tiempo de conocer sus actuaciones... y les dije también que era el riesgo de toda misión profética en la Iglesia, aun de ser criticado por los propios y aun de quedarse solo, pero con la satisfacción de haber tratado de ser fiel al evangelio" (17 de octubre de 1979).

\section{b) La segunda junta demócrata cristiana}

La actitud pastoral y personal de Monseñor respecto a la segunda junta de gobierno, integrada por los demócrata cristianos y los militares fue muy diferente. La razón de esa diferencia la marcó la despiadada represión que desató la Fuerza Armada en contra del pueblo y de la Iglesia. Por eso aunque habia un proyecto de reformas estuvo en contra de ellas, pues eran reformas con represión, reformas con sangre. Y ya no tenía esperanzas en este tipo de proyectos reformistas, mucho menos cuando estaban acompañados del terrorismo del Estado.

El 31 de diciembre, según el diario, Chávez Mena le informó en el desayuno que la democracia cristiana estaba conversando con los militares sobre una alianza para integrar el nuevo gobierno. El 3 y 8 de enero el mismo dirigente demócrata cristiano lo volvió a visitar para informarle de la marcha de las conversaciones, "pero en el ambiente político popular," observó Monseñor en el diario, "todavía no ha arraigado la confianza en la solución de la democracia cristiana aliada con el ejército y se oye, más bien, la opción por la insurrección popular que fomentan los grupos de izquierda" (8 de enero de 1980).

Su nueva posición se encuentra formulada en el diario al relatar una reunión con sus asesores, a la cual asistió Héctor Dada, uno de los nuevos miembros de la segunda junta de gobierno. Este llegó a suplicarle interponer su palabra ante la izquierda para que concediera una tregua al gobierno y poder realizar así sus proyectos reformistas. En la reunión se estudió la petición del gobierno y se dijo que "no era la Iglesia, sino el pueblo el que debía de negociar con el gobierno esta tregua y que el gobierno debía de buscar el arraigo popular y no imponer reformas, sobre todo, si el pueblo se ha dado cuenta que es con el apoyo de una potencia extranjera como es Estados Unidos." De parte de la Iglesia, el gobierno podia esperar la mejor buena voluntad, "pero no podemos ignorar que el pueblo y las organizaciones de izquierda no pueden colaborar con un proyecto donde, al mismo tiempo, existen realidades de represión y pediamos que la parte sana del gobierno... representada en el señor Dada y el doctor Morales Ehrlich, debian de favorecer esa credibilidad del pueblo... Por otra parte, se dijo que la tregua no sólo debía pedirse a la izquierda, sino que la principal fuente de violencias en estos dias es la derecha,

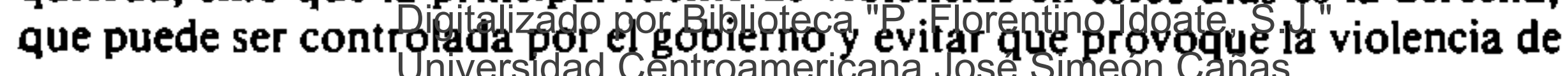


la izquierda. En fin, con toda franqueza se dialogó un tema muy importante..." (22 de febrero de 1980).

Consecuente con este planteamiento, Monseffor no quiso aceptar la invitación que le hiciera la democracia cristiana, a través de un amigo suyo, para asistir a casa presidencial a la proclamación de la ley de reforma agraria. Después de consultarlo, envió a un representante de la curia. Entre sus reparos estaba "lo absurdo" de la invitación pues lo estaban invitando sin decirle oficialmente para qué. Monseñor aprovechó la ocasión para repetir sus objeciones, pues se estaba "masacrando al pueblo, aunque se ve que hay buena voluntad en un sector del gobierno, pero lo que prevalece y ofende tanto al pueblo es ese carácter represivo." Mientras exista, la Iglesia no podrá sentir ninguna confianza en el gobierno, aunque éste fuera demócrata cristiano. Monseñor expresó que quería continuar manteniendo la amistad personal con el enviado y con los demás miembros del gobierno, "pero a un nivel meramente personal. Que como pastor de la Iglesia comprendiera mis reparos y la responsabilidad de mis presencias" (5 de marzo de 1980).

Una prueba de que estaba en lo cierto fueron las acusaciones "ridiculas" que le transmitió casa presidencial sobre el párroco de Cojutepeque, "un gobierno que se fia de tales informaciones no puede ser justo," comentó el 18 de marzo de 1980.

La represión desatada contra el pueblo lo llevó a temer que la violencia desembocara en una guerra civil. El 13 de enero corrian rumores de más violencia, "esperamos que sean prudentes los hombres y sepan negociar a tiempo. Lástima que hay mucha gente animada por este capítulo de la violencia y están llamando casi a la insurrección popular" (13 de enero de 1980). En la reunión del senado del 21 de enero, en vísperas de una gran manifestación convocada por las organizaciones populares para celebrar el levantamiento de los campesinos de 1932, observó que había causado "mucha impresión y la expectativa casi equivalente a una espera de la guerra civil. Hemos analizado la situación y es ciertamente grave, pero nuestro deber como lglesia es mantener la esperanza y ser superiores a todas las falsas noticias y tratar de vivir en la realidad y sobre todo en la conciencia intima con nuestro Dios. Inculcar esto a nuestras comunidades es el deber primordial de esta hora" (21 de enero de 1980). Sin embargo, la psicosis de guerra civil se extendió a todas las oficinas de la curia arzobispal, "casi todo lo ha absorbido hoy ( 22 de enero) esta psicosis de nuestro pueblo y no han faltado en el arzobispado muchas visitas, también bajo el nerviosismo de esta situación de violencia..." (22 de enero de 1980).

\section{Conclusión: Monseñor, un pastor querido}

Monseñor, en medio de tantas dificultades e incomprensiones como se han apuntado en esta segunda parte del estudio, experimentó profundas satisfacciones pastorales. Lo que más le gustaba era sentirse pastor y amigo de todos. Asi resumió la visita que hizo a Potonico, (Chalatenango), el 20 de diciembre de 1978. En el pueblo lo recibieron con varios carteles "muy significativos," pero el más significativo de todos era el que decia "nuestro pastor y 
amigo." Esta frase sintetiza bien toda su actividad pastoral y todo el diario. Eso quería ser él, incluso para quienes no aceptaban ni sus ideas ni sus actuaciones. Deseaba profundamente que cualesquiera que fueran las diferencias, siempre pudiera ser pastor y amigo de todos los salvadoreños, especialmente del pueblo salvadoreño.

Sus mayores satisfacciones pastorales, según lo que se desprende de sus relatos y descripciones en el diario, eran el pueblo fervoroso y acogedor a quien se debía de cuerpo entero, el clero que crecía en madurez para dialogar y en servicio a favor del pueblo tan necesitado y tan agradecido, sin perder su identidad sacerdotal, los seminaristas de quienes esperaba supieran responder a estas exigencias, los religiosos quienes se habian sumado a esta empresa, las comunidades cristianas que iban creciendo bajo su inspiración y cuidado profundizando en su fe y en sus compromisos políticos, en una palabra, se estaba construyendo el reino de Dios alrededor del pastor y del amigo. Monseñor sentia que estaba convirtiendo al pueblo salvadoreño en pueblo de Dios peregrino en medio del terrorismo del Estado, la esperanza efimera de un proyecto reformista y de las reformas con más represión de la democracia cristiana y la Fuerza Armada.

Monseñor volvía muy impresionado de sus giras apostólicas por las comunidades de la arquidiócesis, volvía "de veras crecido, confirmado en mi deseo de servir a este noble pueblo de Dios que el Señor me ha encomendado"' (4 de enero de 1979). La experiencia del funeral de Octavio Ortiz recoge de forma más explícita este sentimiento del pastor, "era una verdadera manifestación espléndida de solidaridad, de sufrimiento, de amor, de entrega a la causa de Jesucristo. La muchedumbre estuvo cariñosa con los sacerdotes y con su obispo, al que saludaban con aplausos, con beso de mano, etc... Luego terminó esta ceremonia con mucha satisfacción. iQué bien responden los pueblos cuando se les sabe amar!" (21 de enero de 1979).

El pueblo reconoció a Monseñor como su pastor y su amigo. A él acudió en los casos de extrema necesidad buscando consuelo y aliento, también buscando su voz para hacer oir la suya propia tanto tiempo silenciada por el terror y la represión. En diversas ocasiones Monseñor fue aclamado por el pueblo, no sólo por el de su diócesis que estaba en contacto más directo con él, sino también por el de las otras diócesis del país. Asi, el 25 de marzo de 1979, mientras participaba, junto con los demás obispos, en la celebración del 25 aniversario del seminario de Santa Ana, "entre la muchedumbre que asistía se escucharon algunos vivas a Monseñor Romero. Lo cual no dejó de inquietarme y por lo cual también apenas terminó la misa procuré evadirme para evitar cualquier problema" (25 de marzo de 1978).

La segunda aclamación ocurrió en San Miguel el 21 de noviembre de 1979, a donde había ido a concelebrar con los demás obispos por celebrarse la fiesta de Nuestra Señora de La Paz, patrona del país. La catedral estaba repleta de gente. La homilía la pronunció el nuncio, quien además presidia la concelebración. Pero Monseñor no se sintió a gusto con la liturgia, "sentí, francamente, mucha pena que la homilia que pudo ser un mensaje para este pueblo hambriento de orientación y de inspiración se haya defraudado, en gran parte, 
por una homilía muy descolorida y abstracta del señor nuncio. Respeto su personalidad y su misión, pero francamente aquí no se cumplió con el papel profético de la Iglesia en una circunstancia tan hermosa como es una fiesta de la patrona del país frente a un pueblo necesitado de un mensaje más vibrante, vivido y profundo." Pero eso no fue todo, a causa de las divisiones internas en la conferencia episcopal, los demás obispos marginaban a Monseñor, incluso en estas apariciones públicas, "noté en el episcopado siempre el afán de marginarme, pero el pueblo, por otra parte, me dio una calurosa ovacion a la salida de la Iglesia, que ya presentía y por eso me quedé el último, para no ofender con esta especie de rivalidad popular a mis hermanos que salieron más privadamente. Le agradezco al pueblo y no siento vanidad, sino alegría de sintonizar con los sentimientos del pueblo que espera de sus profetas y pastores una solidaridad cada vez más profunda" (21 de noviembre de 1979). Monseñor pudo ser pastor por su fe y por su esperanza, pero historicamente lo que lo mantuvo frente a las dificultades y a la soledad intra-episcopal fue el cariño del pueblo.

La postulación al premio Nobel de la paz la aceptó "no en mi carácter personal, sino en la pastoral que trato de llevar en la arquidiócesis y la cual corresponde a inquietudes de pastores y comunidades de diversos puntos del continente" (19 de abril de 1979). Asimismo el doctorado honoris causa de la Universidad de Lovaina, el cual creyó debía aceptar "ya que no se trata sólo de un honor personal, sino de un estímulo a una causa que en la Iglesia necesita mucho apoyo," y por el cual "he dado gracias a Dios por este nuevo testimonio de su amor y de su estímulo" (24 de noviembre de 1979). En esta ocasión le costó mucho salir del país, pero al final acabó aceptando el viaje por tratarse precisamente de una alta distinción para la arquidiócesis.

Monseñor sentía que su deber era permanecer en San Salvador, pero él interpretó el viaje como "un servicio a la diócesis, de un apoyo a nuestra pastoral y, en este sentido, creo que debo hacer el sacrificio de ir" ( 24 de enero de 1980). El 28 de enero, al despedirse iba muy preocupado de lo que pudiera suceder durante su ausencia, pero una de las hermanas carmelitas le dio ánimos recordándole que quien apacentaba a su pueblo era el Señor y "que fuera tranquilo, que todos íbamos a rezar para que el Señor apacentara esta grey que tengo que dejar aun sin quererlo, pero por ir a cumplir otro deber..." (28 de enero de 1980). Para Monseñor, pues, estas distinciones no sólo tenían una dimensión personal, pero ni siquiera arquidiocesana, sino que, además, eran un reconocimiento a toda una linea eclesial que necesitaba de mucho apoyo porque contaba con detractores igualmente poderosos; él mismo experimentaba esta contradicción en su ministerio.

No se arrepintió de haber aceptado ir a recibir el doctorado personalmente. El acto de investidura fue, en realidad, un gran elogio para la arquidiócesis (2 de febrero de 1980). Cuando ocupó el estrado para dirigirse a la concurrencia la muchedumbre congregaba en la sala de la universidad lo saludó "con un caluroso aplauso, casi interminable, que agradecí naturalmente. Dije unas palabras que me habian preparado en flamenco, para decir que senti mucho no poder hablar en su lengua, pero hablaría en el lenguaje de mis pobres a los que yo venía a representar. Fue saludado este gesto de esfuerzo por hablar su len- 
gua con otro caluroso aplauso. Y empecé mi disertación en español sobre la djmensión política de la fe a partir de los pobres"' (2 de febrero de 1980).

Sus impresiones generales se encuentran recogidas en las siguientes líneas del diario, "fueron cuarenta minutos que yo noté que había una atención extraordinaria ya que aunque yo hablaba en español, el padre Juan había preparado una traducción en flamenco que todos iban siguiendo y, al terminar, aquel aplauso fue muy extraordinario. Me sentí abrumado, de verdad, por el entusiasmo y la acogida, sobre todo de la juventud universitaria de Lovaina que impulsaba a continuar el aplauso a toda la concurrencia..." Cuando hicieron su elogio personal, "era un elogio muy grande," y luego, cuando le impusieron la toga doctoral fue de nuevo ovacionado.

El acto fue seguido de una recepción formal "muy cordial, muy animada... una verdadera fiesta del espiritu y de la cultura." En el diario dejó constancia que lo que más le gustó fue el contacto personal con los invitados a la recepción oficial y al almuerzo posterior. Todos estos encuentros personales le dieron más ánimo y lo confirmaron en su misión, "los saludos en particular de todas estas personas me llenaron de mucho aliento. Todos me decian que habia sido un mensaje muy oportuno y que habia hecho pensar a muchos en la situación de nuestro país y las perspeclivas cristianas y teológicas de nuestra pastoral." Más tarde, aún sacó tiempo para reunirse con los salvadoreños exiliados, quienes "querian compartir sus preocupaciones por nuestro país" ( 2 de febrero de 1980).

Estos reconocimientos internacionales le ayudaron mucho a confirmarse en la línea que estaba siguiendo, en particular de cara al sector eclesiástico salvadoreño, donde era duramente criticado y atacado. En medio de esta situación dificil por la crisis política y dificil por la incomprensión de su pastoral por parte de la conferencia episcopal lo animó y orientó también el saber que "había obispos en diversos paises de América Latina en situaciones parecidas porque ni sus hermanos obispos ni el ambiente les comprende muchas veces ese compromiso que el evangelio y la doctrina actual de la Iglesia pide a sus pastores. Espero, pues, ser fiel a esta doctrina y pido por todos aquellos hermanos obispos que están en estas mismas difíciles situaciones" (7 de abril de 1978). De la misma forma le resultó muy interesante escuchar que otras iglesias y conferencias episcopales latinoamericanas se identificaran con el pueblo y se enfrentaban, por necesidad, con los gobiernos "que no comprenden al pueblo y la necesidad de optar, como aconseja Puebla, por los pobres, es un hecho admitido y que va en mucho progreso de la Iglesia que busca auténticamente ser la Iglesia de Jesucristo" (29 de mayo de 1979).

Comprando libros de teología en una libreria de Guatemala, le impresionó el ser reconocido por otros sacerdotes guatemaltecos, quienes le dieron muestras de aprecio y de cariño, "yo he agradecido al Señor y a ellos por este testimonio de fraternidad que, gracias a Dios, se disfruta aun en otros paises donde uno piensa no ser tan conocido"' (5 de diciembre de 1979).

En este mismo sentido fue de un consuelo especial la visita que le hizo el cardenal Aloisio Lorscheider, enviado por la santa sede como visitador apostólico a la arquidiócesis. El cardenal Lorscheider escogió quedarse a convivir 
con Monsefior en la residencia del hospitalito, en vez de residir en la nunciatura o en el seminario, "así manifiesto que estoy contigo," le dijo (31 de diciembre de 1979). Platicaron muy cordialmente largo rato, "él lleva buenas impresiones de mi trabajo, de la gente con quien ha conversado y cree que se trata de sugerir personalmente al Papa un refuerzo del episcopado y una solución más radical a la situación de nuestra Iglesia. El cree que mis actuaciones, después de haber leído mis cartas pastorales, las homilías y haber conversado con gente imparcial e inquieta de la vida de la Iglesia (que) es un trabajo que merece el apoyo, lo cual me ha dejado a mi nuevamente confirmado en el trabajo que vamos llevando en nuestra pastoral"' ( 2 de enero de 1980).

Su último aniversario episcopal, el noveno, fue una síntesis de lo que fue su vida de pastor. En efecto; el 21 de junio de 1979, las hermanas del hospitalito le pidieron celebrar la Eucaristía ahí mismo “...celebré esta misa primera con mucha intimidad ante el Señor y en representación del pueblo de Dios, un pequeño grupo de religiosas y enfermos.." comentó en su diario. Pero ese mismo día debió también presidir el funeral del P. Rafael Palacios, lo cual "me pareció otra forma grandiosa de celebrar este aniversario..." De esta celebración pública comentó lo siguiente, "...me ha parecido muy significativo celebrar (este aniversario) con un sacerdote asesinado y con la plena solidaridad de todos los sacerdotes de la arquidiócesis y muchos que han venido de otra diócesis, incluso el señor obispo de Santiago de María..." (21 de junio de 1979). 